\title{
Ostracoda (Arthropoda, Crustacea) from the Riachuelo Formation, Sergipe-Alagoas Basin, Brazil, Upper Aptian-Albian
}

\author{
Lucas Silveira ANTONIETTO ${ }^{1, *}$, Dermeval Aparecido do CARMO $^{2}$, Marta Claudia \\ VIVIERS $^{3}$, João Villar Queiroz NETO ${ }^{4} \&$ Gene HUNT $^{5}$ \\ ${ }^{1,2}$ Laboratory of Micropaleontology, Institute of Geosciences, University of Brasilia, \\ Darcy Ribeiro Campus, CEP 70919-970 Brasilia, Distrito Federal, Brazil. \\ ${ }^{3,4}$ Petrobras-CENPES-PDGEO/BPA, Horácio Macedo Avenue, 950, CEP 21940-900, \\ Rio de Janeiro, Rio de Janeiro, Brazil.
}

${ }^{5}$ Department of Paleobiology, National Museum of Natural History, Smithsonian Institution, 10th Street \& Constitution Avenue NW, 20560-0121 Washington D.C., U.S.A.

*Corresponding author: antoniettols@gmail.com

2Email: derme@unb.br

${ }^{3}$ Email: mcviviers@oi.com.br

${ }^{4}$ Email: joaovq@petrobras.com.br

${ }^{5}$ Email: hunte@si.edu

\footnotetext{
${ }^{1}$ urn:Isid:zoobank.org:author:4E63F407-03D6-4D06-9318-72FA2A23E014

${ }^{2}$ urn:lsid:zoobank.org:author:911A76DB-38C3-482F-A7AC-2D57F0AFF90D

${ }^{3}$ urn:Isid:zoobank.org:author:B0CACF44-1ED6-49E0-928B-EA7FF769854F

${ }^{4}$ urn:1sid:zoobank.org:author:5BB35DBF-70E2-450A-A521-6ECE846052F9

${ }^{5}$ urn:1sid:zoobank.org:author:C94AA495-663C-4C5E-9D86-BEF1A32528BD
}

\begin{abstract}
The Sergipe-Alagoas Basin has one of the most complete, exposed lithological successions of the Cretaceous period in the continental margin of Brazil. It captures several phases of the evolution of the South Atlantic Ocean, including rift, gulf and drift. The upper Aptian-Albian Riachuelo Formation corresponds to the first stages of the southern proto-Atlantic Ocean invasion in that basin. The present study reviews the taxonomic identification and ecology of 39 ostracod species of this formation, proposing a new genus - Gabonorygma gen. nov. - and three new species - Praebythoceratina deltalata sp. nov., Gabonorygma sergipana gen. et sp. nov. and Brachycythere smithsoniana sp. nov. Other taxa include Conchoecia? sp. 1, Cytherella sp. 1, C. besrineensis comb. nov., Cytherelloidea aff. globosa, C. btaterensis, Bairdoppilata sp. 1, Bairdoppilata sp. 2, B. comanchensis comb. nov., B. pseudoseptentrionalis, Robsoniella falklandensis, Cetacella sp. 1, Paracypris eniotmetos, Harbinia sinuata?, H. crepata, Liasina sp. 1, Praebythoceratina amsittenensis comb. nov., P. trinodosa comb. nov., Patellacythere sp. 1, P. shimonensis comb. nov., Xestoleberis? sp. 1, Xestoleberis? sp. 2, Apatocythere? sp. 1, Neocythere? aff. pseudovanveeni, N. (Physocythere) tenuis, Aracajuia antiqua comb. nov., A. benderi, A. fragilis comb. nov., Eocytheropteron sp. 1, Metacytheropteron aff. minuta, Microceratina? sp. 1, M. azazoulensis, Veenia guianensis, Algeriana? sp. 1, Quasihermanites? sp. 1 and Sergipella viviersae.
\end{abstract}


Keywords. Ostracoda, Early Cretaceous, northeastern Brazil, Proto-Atlantic Ocean, Gabonorygma gen. nov.

Antonietto L.S, do Carma D.A., Viviers M.C., Neto J.V.Q. \& Hunt G. 2016. Ostracoda (Arthropoda, Crustacea) from the Riachuelo Formation, Sergipe-Alagoas Basin, Brazil, Upper Aptian-Albian. European Journal of Taxonomy 244: 1-57. http://dx.doi.org/10.5852/ejt.2016.244

\section{Introduction}

The Sergipe-Alagoas Basin is a marginal basin located in northeastern Brazil (9-11 ${ }^{\circ} 30^{\prime} \mathrm{S}, 37-35^{\circ} 30^{\prime} \mathrm{W}$ ). Its mainland portion is between 16 and $50 \mathrm{~km}$ long and $170 \mathrm{~km}$ wide, covering a total area of approximately $11000 \mathrm{~km}^{2}$ (Feijó 1994), bounded by the Pernambuco-Paraíba Basin to the northeast (Maragogi structural high) and the Jacuípe Basin to the southwest (Itapuã Fault) (Fig. 1). It has been the subject of several studies, mainly due to the amount of data acquired through well and outcrop sampling, seismic lines, gravimetric and magnetic surveys, etc. Most of these studies focused on its oil and gas producing strata, i.e., its basement (Proterozoic), the Carmópolis oil field (Late Jurassic-Aptian) and the Calumbi Formation (Santonian-Cainozoic) (Marques 1965; Souza-Lima et al. 2002; Campos Neto et al. 2007; Graddi et al. 2007).

Since the beginning of studies on ostracods from the Sergipe-Alagoas Basin in the 1960s (Krömmelbein 1962, 1964), the upper Aptian-Cenomanian Riachuelo Formation was at the heart of important findings. Krömmelbein (1967) identified and described the first Albian species of the basin, Aracajuia benderi Krömmelbein, 1967 and Sergipella transatlantica Krömmelbein, 1967. Following that, Krömmelbein \& Weber (1971) found new taxa in the basal, transitional layers of the formation, in an extensive work on the Aptian-Albian formations of northeastern Brazil.

Bate (1972), followed by Smith (2000), worked extensively on the late Aptian lagerstätte-quality fossils of Harbinia micropapillosa (Bate, 1972). The most extensive taxonomic summarization of the Riachuelo Formation so far was published by Viviers et al. (2000), while establishing the first ostracodbased biostratigraphy of the basin, although no taxonomic details were provided. Do Carmo et al. (2008, 2012), Poropat \& Colin (2012) and Antonietto et al. (2012, 2013) presented subsequent taxonomic updates for some of those species. The most recent taxonomic, stratigraphic and paleozoogeographical reviews of the late Aptian-early Albian of the formation is given by Antonietto et al. (2015).

An extensive taxonomic review of several ostracod species and genera of the upper Aptian-Albian strata of the Riachuelo Formation is herein presented. Its main objective is to better identify and describe the ostracod fauna observed in the formation during that stage. These species are also compared with those of coeval lithological units worldwide, so as to optimize synonymies between their faunas. The present study will impact future analyses of several aspects of these strata, such as biostratigraphical, paleoecological and paleozoogeographical correlations.

\section{Geological and regional settings}

The Sergipe-Alagoas Basin was originally described by Schaller (1969), and extensively reviewed by Feijó (1994) and Campos Neto et al. (2007). The basin lithology is mostly co-relatable to the evolutionary stages of the formation and expansion of the South Atlantic Ocean: syneclise, pre-rift, rift, gulf and drift (Ponte \& Asmus 1976; Feijó 1994). The upper Aptian-Cenomanian Riachuelo Formation was established at the beginning of the drift phase, due to a transgression that allowed the sedimentation of openly marine sediments. This formation is composed of three members. At the basin margins and grabens, deltaic fans were formed and the coarse sediments brought by them constitute the Angico Member. At lower sedimentation areas, the Maruim Member dominates, with its carbonate ramps 
and dolomitized oolitic/oncolytic banks deposited under fluctuating sea level conditions. The Taquari Member, on the other hand, corresponds to the calcareous mudstones and shales from lagoon and slope environments (Campos Neto et al. 2007) (Fig. 2).

The upper Aptian-Albian sediments of the Sergipe-Alagoas Basin were deposited during the establishment of the "Megatethys Ocean", or "Mid Cretaceous Tethyan Realm" (Dias-Brito 2000). Based on the worldwide equatorial occurrence of pithonellid species during that age, a set of tropical marine environments occupying both hemispheres, approximately between latitudes $40^{\circ} \mathrm{N}$ and $40^{\circ} \mathrm{S}$,

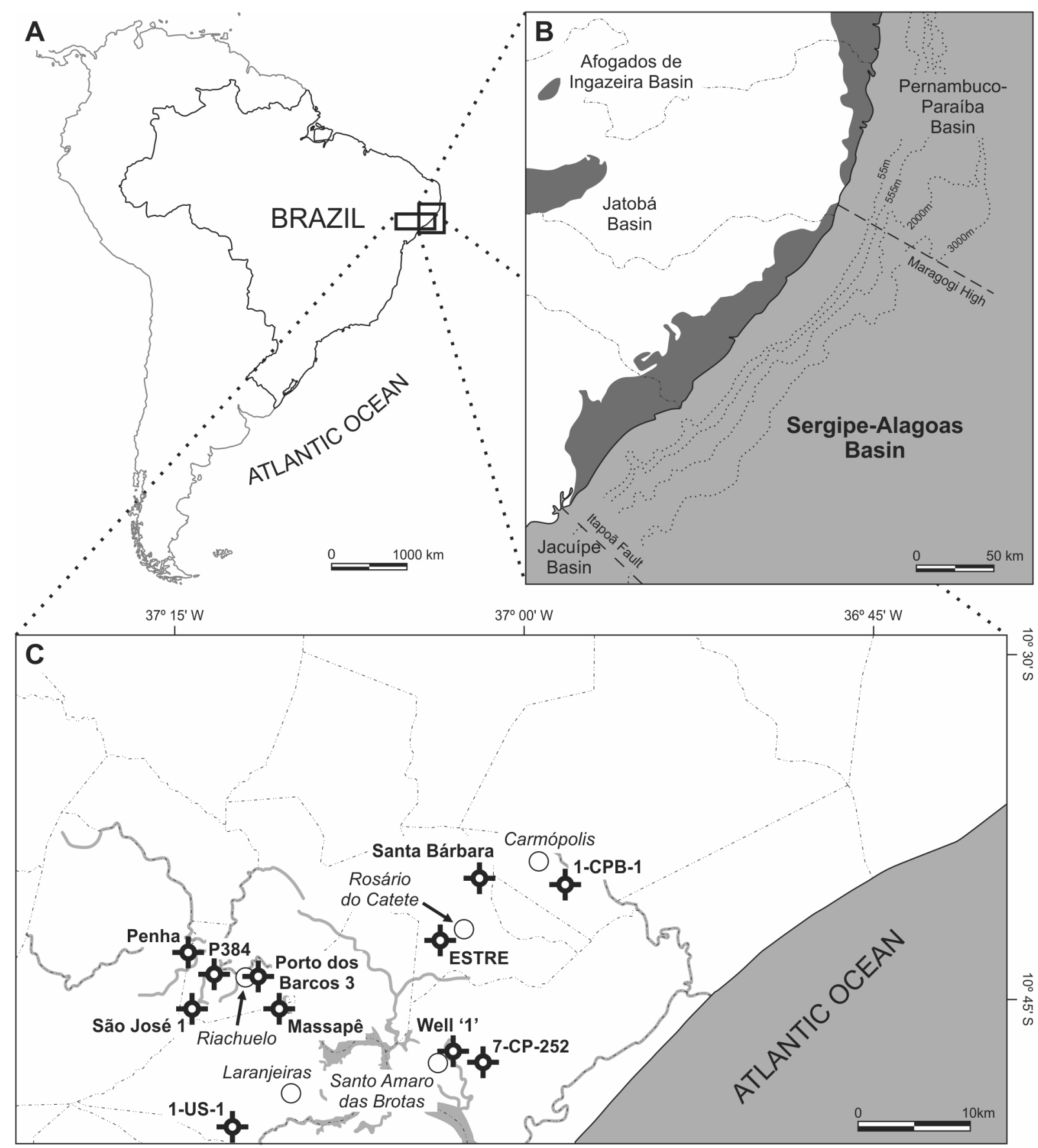

Fig. 1. Location of the Sergipe-Alagoas Basin in South America and Brazil, along with the outcrops and wells studied in the present work. 
was proposed that would enable long-range distributions for these taxa during the Albian-Turonian. The southernmost limit of Megatethys in the Central Proto-Atlantic Ocean was coincident with the Walvis Ridge, an effective topographic barrier at that time. The concept of the upper Aptian-Albian Megatethys also seems to be applicable to ostracods, as summarized by Colin \& Andreu (1990), Andreu (2002), Piovesan et al. (2013) and Antonietto et al. (2015) (Fig. 3). However, during the Cenomanian, constraints related to the presence of the Walvis Ridge seemed to vanish, as distribution of taxa across it began to appear (Antonietto et al. 2015).

Most of the visited outcrops were composed of interbedded Taquari and Angico Member sections. The Estre, Fazenda Santa Bárbara and Porto dos Barcos 3, however, were entirely in the Taquari depositional context, while the Massapê outcrop is partially in the Maruim Member. The Fazenda Santa Bárbara outcrop $\left(10^{\circ} 39^{\prime} \mathrm{S}, 37^{\circ} 01^{\prime} \mathrm{W}\right.$ ) (Fig. 4A) comprises reddish calcareous mudstones, abundant in gastropod shells, but also possibly containing brachiopods. The Penha outcrop $\left(10^{\circ} 42^{\prime} \mathrm{S}, 3^{\circ} 13^{\prime} \mathrm{W}\right)$ (Fig. 4B) presents fine yellow, calcareous sandstones followed by grey calcareous shale, laminate calcareous siltstones and fine laminate sandstones. Abundant occurrences of gastropods, bivalves and possible brachiopods are observed.

The Estre outcrop $\left(10^{\circ} 41^{\prime} \mathrm{S}, 37^{\circ} 02^{\prime} \mathrm{W}\right.$; Fig. $\left.4 \mathrm{C}\right)$ is a succession of marly to calcareous mudstones, carbonate/clay interbedding and bioturbed cream-coloured shale rich in impregnations of fossil-rich siliceous concretions and phytofossils. The outcrop P384 (10 $43^{\prime} \mathrm{S}, 37^{\circ} 12^{\prime} \mathrm{W}$; Fig. 4D) comprises creamcoloured laminate mudstones at both its bottom and top parts, with a mid-section of yellowish calcareous siltstones and cream-coloured sandstones. Ichnofossils, bivalves, phytoclasts and possible brachiopods are identifiable. The Porto dos Barcos 3 outcrop $\left(10^{\circ} 43^{\prime} \mathrm{S}, 37^{\circ} 10^{\prime} \mathrm{W}\right.$; Fig. 4E) is a slightly saprolitic sequence that shows, bottom to top, levels of creamy calcareous siltstone, creamy and grey calcareous siltstone, yellowish mudstones, creamy calcareous siltstones and creamy micaceous mudstones. The

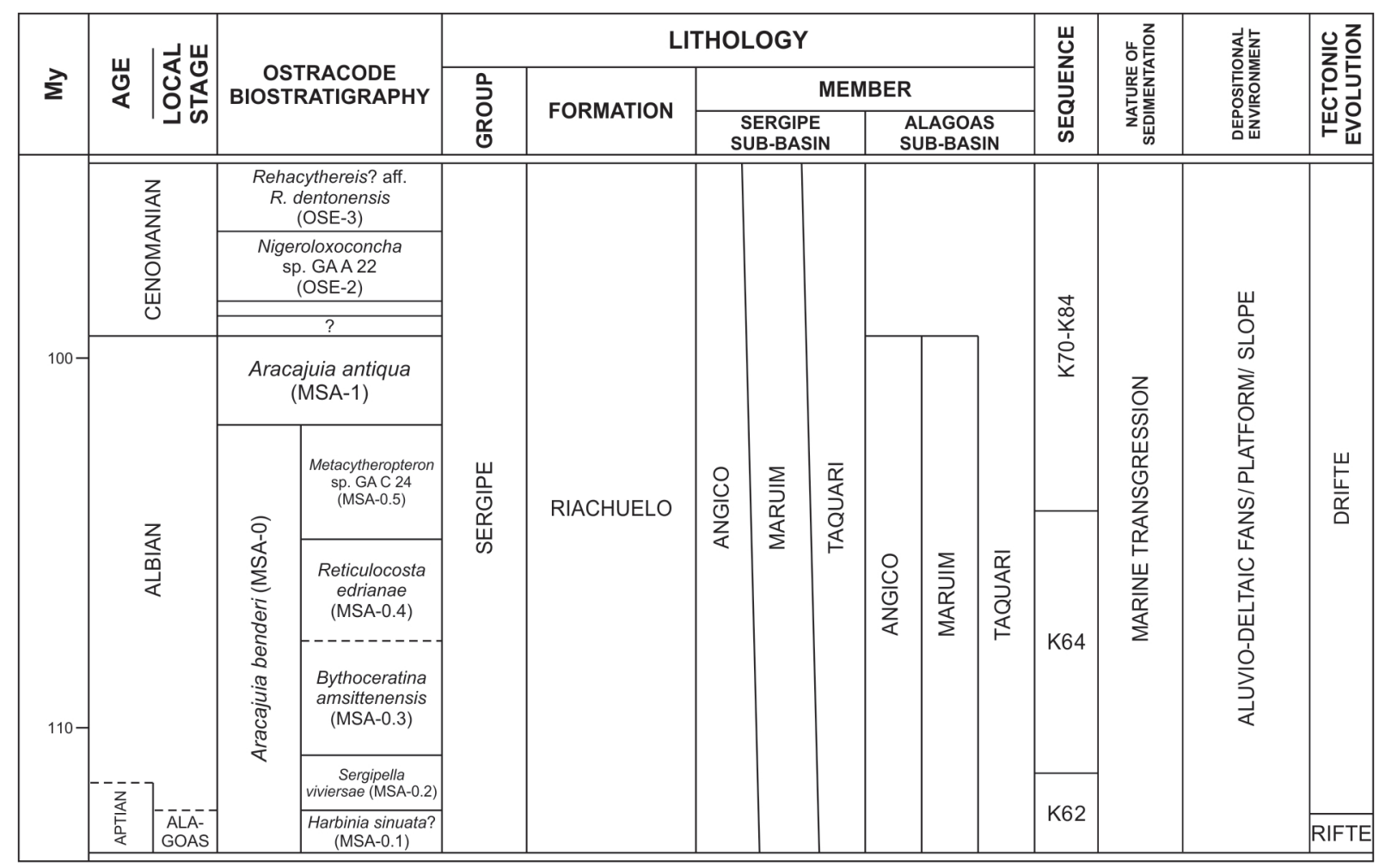

Fig. 2. Lithological and biostratigraphical profiles of the Riachuelo Formation, Sergipe-Alagoas basin, northeastern Brazil, after Campos Neto et al. (2007) and Antonietto et al. (2015). 
fossil record includes echinoderm spines, undetermined invertebrates, ammonoids, gastropods and bivalves.

The outcrop named Massapê $\left(10^{\circ} 06^{\prime} \mathrm{S}, 37^{\circ} 10^{\prime} \mathrm{W}\right.$; Fig. 4F) begins with yellow to cream-coloured laminate calcareous and micaceous siltstones, overlain by fine to very fine yellowish calcareous/micaceous sandstones, followed by intercalations of yellow to creamy siltstones and mudstones, grey greywacke with dark impregnations and interposed levels of oolitic calcarenite and yellow sandstones with smoky quartz grains, sparse ooids and ichnofossils. The São José 1 outcrop $\left(10^{\circ} 44^{\prime} \mathrm{S}, 37^{\circ} 13^{\prime} \mathrm{W}\right.$; Fig. 4G) presents the most complex lithology among those sampled. The basal siltstones with calcareous impregnations are covered by yellow silty, fine sandstones and calcareous yellow siltstones with limestone levels; massive yellow sandstones; limestone with abundant ichnofossils; marl-limestone intercalations; solid limestone; non-rhythmic intercalations of creamy laminate siltstone, marls and mudstones; and, finally, creamy to yellowish, medium to laminate thin calcareous sandstones. Fossil groups include ichnofossils, bivalves, gastropods, cephalopods (not associated with any particular stratum) and phytofossils.

\section{Material and methods}

The material studied herein comprises a total of 331 samples from the State of Sergipe, Brazil: 142 collected from outcrops of the Riachuelo Formation (Estre, Fazenda Santa Bárbara, Porto dos Barcos 3, Penha, São José 1, Massapê and P384), plus 189 from well cores (1-CPB-1, 7-CP-252, 1-US-1 and well ' 1 ') owned by Petróleo Brasileiro S.A. (Petrobras) (Table 1). Samples were prepared and packaged according to the methodology developed by the Laboratory of Micropaleontology of the University of Brasília (LabMicro-UnB), Brasília, Brazil. Sixty grams of each sample were prepared, and the remainder was packed in double plastic bags with catalogue-record sheets. This material is stored in the specific cabinet for prepared samples of the same laboratory.

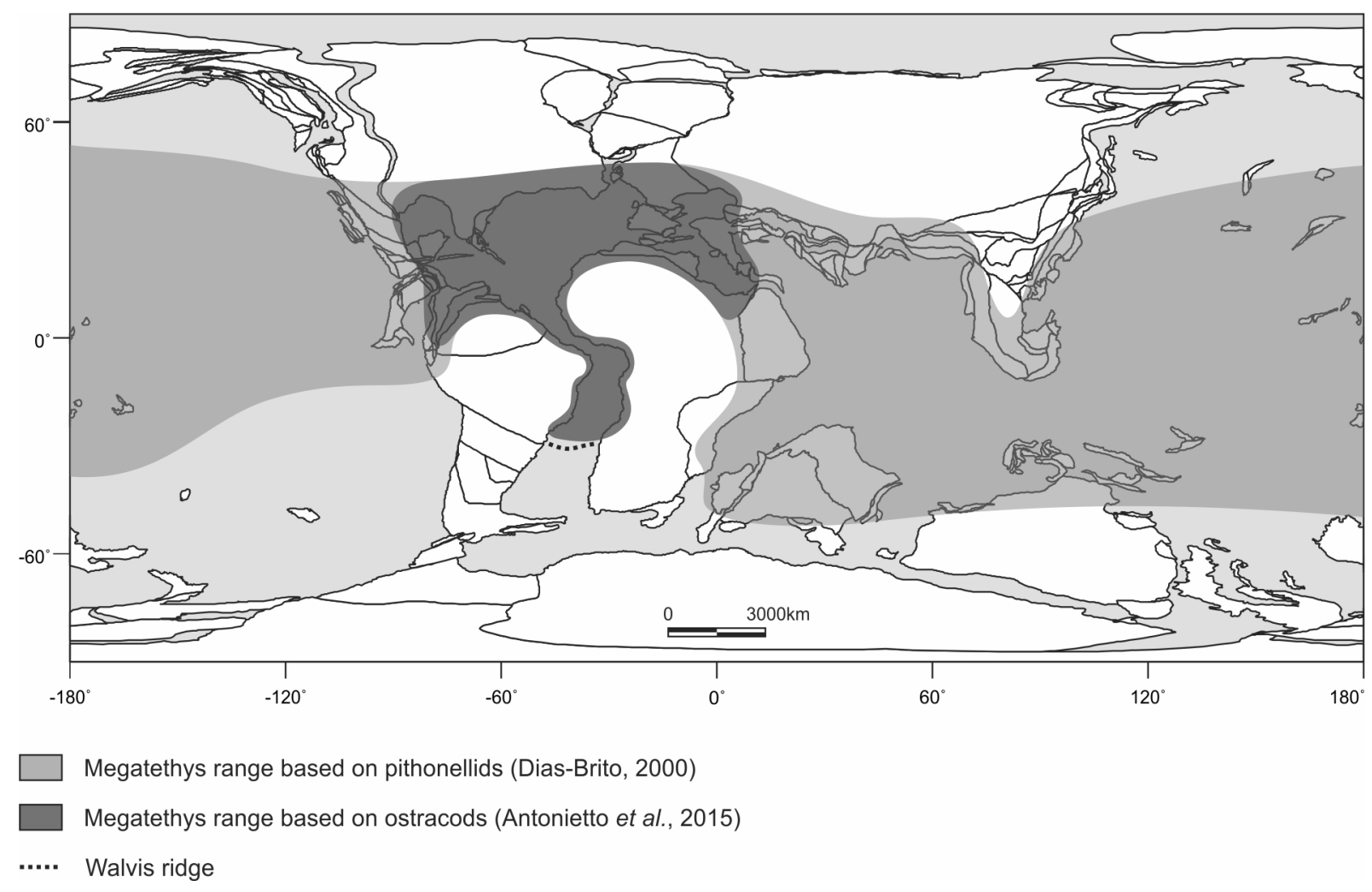

Fig. 3. Extension of the "Megatethys Ocean", or "Mid Cretaceous Tethyan Realm", during the Albian. 

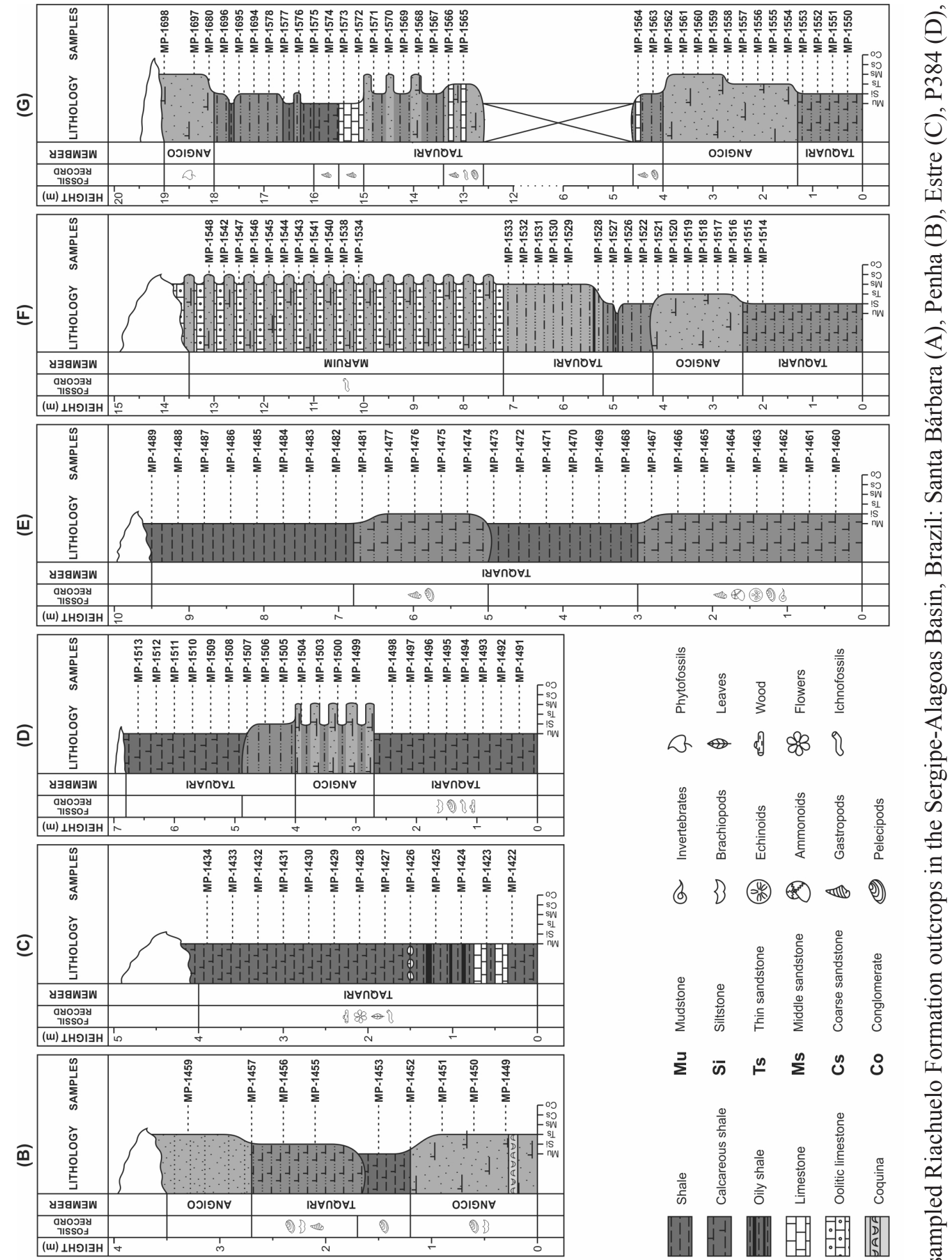

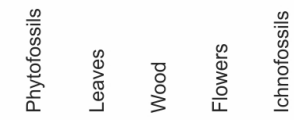

a \& 88

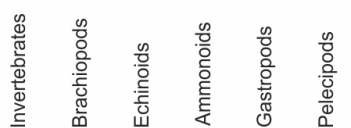

ติ

๑ี

อ

$\stackrel{2}{\stackrel{1}{4}}$

שี

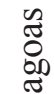

b) 3 (x)

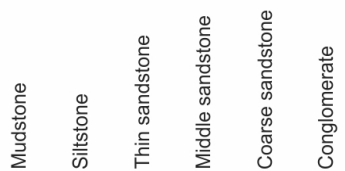

莺

.0

एँ

घี 정

$\Sigma$ क 2 0 응

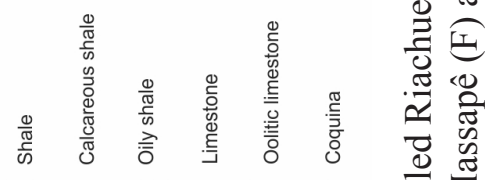

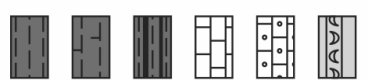

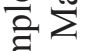
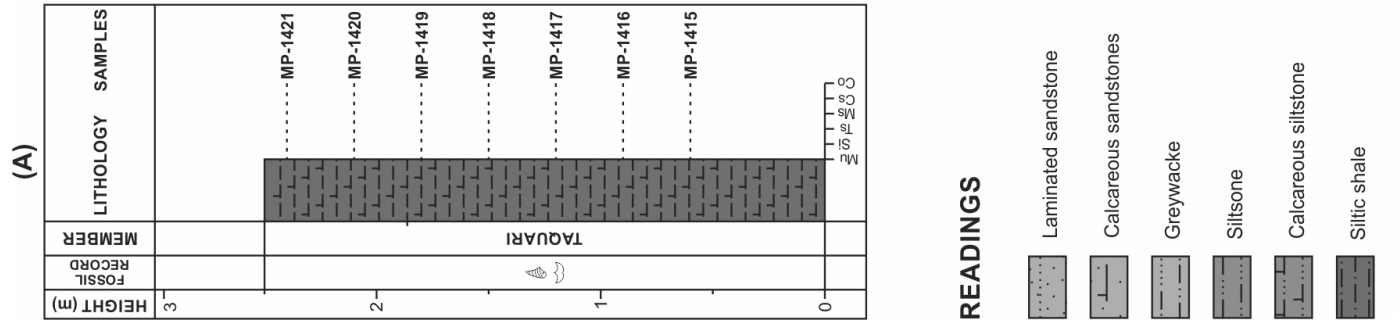

藏

क्ठ ठ

응 츤

$\stackrel{m}{=}$

$\because 7$

فำ 융 
ANTONIETTO L.S. et al., Brazilian latest Aptian-Albian marine ostracods

Table 1. Sampled depths from wells ceded by Petrobras S.A. studied in the present work.

\begin{tabular}{|c|c|}
\hline Well & Sampled depths studied (m) \\
\hline $1-\mathrm{CPB}-1$ & $198,222,345.5,348,348.5,35,354.5,355.5,356.5,358.5,359.5,360.5$ and 364.5 \\
\hline 1-US-1 & $\begin{array}{l}0,12,30,60,90,98.5,99.5,100.5,101.1,120,150,180,210,240,246,261,270,270.05,276, \\
291,300,306,321,330,336,351,360,366,381,390,396,399,399.5,400.5,411,420,426,441, \\
450,456,471,480,486,501,510,516,531,540,541,546,552,552.5,553.5,554.5,555.5,561, \\
570,576,591,600,606,621,630,636,651,660,666,678,679.55,681,690,696,711,720,726, \\
741,750,756,771,780,786,801,804,810,816,831,840,846,861,870,876,891,900,906,921, \\
930,936,951,953,953.1,960,966,981,990,996,1011,1020,1026,1041,1050,1056,1067, \\
1067.25,1071,1080,1086,1101,1110,1116,1131,1139.2,1139,1140,1146,1161,1170,1200, \\
1230,1260,1290,1320,1350,1380,1395,1410 \text { and } 1425\end{array}$ \\
\hline 7-CP-252 & $\begin{array}{l}466,466.2,466.7,467.5,467.55,467.9,468.7,469.2,469.75,469.8,470.15,470.6,470.65, \\
471.25,471.8,472.25,472.3,472.6,473.3,473.8,474.45,474.5,474.85,475.3,475.85,476.25, \\
476.3,476.5,476.7,477.1,477.5,477.95,478.45,478.85,479.5,480.3,480.55,480.95,481.6, \\
481.8,482.9,483.5,483.55,484.15,484.4,484.75,485.6,486.05,486.45,487,488.15,488.4, \\
489.15,489.2,489.7,490,490.1,490.35,492.95,493,493.45,493.5,494.3,494.75,495.85, \\
495.9,496.55,496.6,497.7,498.3,498.6,502.4,503.35,503.53,506.3,507.15,508.4,508.75, \\
509.3,511.35,511.4,511.9,512.7,514,514.05,515,516,517.45,518.3,518.8,521,521.4,523.9, \\
527.1,534.8,535.55,540.05,552,553.4,558.9,560.3,564.8,567.15,568.15,568.95 \text { and } 581.35\end{array}$ \\
\hline Well ' 1 ' & 510 and 540 \\
\hline
\end{tabular}

The sample contents separated for preparation were treated at the Laboratory of Micropaleontology as follows: first they were submerged in a solution containing $30 \%$ hydrogen peroxide $\left(\mathrm{H}_{2} \mathrm{O}_{2}\right)$, aiming to fragment rock particles. Ethanol at $92 \%$ was added to interrupt this reaction, and after that, the separation of grains by size took place, using mesh sieves of 630, 250, 160 and $80 \mu \mathrm{m}$. For samples MP-1430 to MP-1434, MP-1493, MP-1494 and MP-1678, the $80 \mu \mathrm{m}$ sieve was replaced by a $90 \mu \mathrm{m}-56$ $\mu \mathrm{m}$ dual set.

Carapaces and valves of several species were studied at the LabMicro-UnB and the Smithsonian National Museum of Natural History (NMNH), Washington D.C., United States. For comparison, specimens of several genera belonging to NMNH collections were also studied. The study of the additional 189 already processed samples from Petrobras was done at the Centro de Pesquisas Leopoldo Américo Miguez de Mello (CENPES), Rio de Janeiro, Brazil. The type material of 37 species from 16 families is housed in the Research Collection of the LabMicro-UnB, under the prefix "CP" ("Coleção de Pesquisa") and numerations from 668 to 735 and from 756 to 769 . Additional type material from two other species is at CENPES, totaling three specimens under the prefix "LBP" ("Laboratório de Bioestratigrafia da Petrobras").

Height, length and width measurements for these specimens were mostly taken using an Olympus SZX12 microscope with a Q5 camera, plus QCapture 7 software. Some additional measurements were made with a Heerbrugg Wild M3Z microscope and Leica measuring lenses. Most of the scanning electron microscopy (SEM) was done using a Philips XL-30 scanning electron microscope and palladium-gold coating to enhance the contrast and definition. Additional photos were taken in a Zeiss EVO 40 at CENPES, under palladium-gold, and a JEOL JCM-5000 Neoscope at the LabMicro-UnB, under carbon coating. 
The suprafamiliar classification used here follows Liebau (2005). The taxonomy of lower ranks are based on Maddocks (1969), Hanai (1970), Gründel \& Kozur (1972), Gründel (1974, 1976, 1977, 1978a, 1978b) and Hou et al. (2002), as indicated in the "Remarks" sections for each species. The morphological terminology is the same as that in Sylvester-Bradley \& Benson (1971), except for the usage of the term "ridge", in which Kesling (1951) is followed. Terms used to describe the curvature of anterior and posterior ends - infra-curvate, equi-curvate and supra-curvate - were adopted from Lüttig (1962). The use of the terms "hypotype" and "homeotype", used to categorize types not contemplated by the ICZN, follows Schenk \& McMasters (1956). Thirty-nine species were recovered and identified from the present samples.

\section{Taxonomy}

Subclass Ostracoda Latreille, 1802

Superorder Myodocopomorpha Kozur, 1972

Order Halocypridida Skogsberg, 1920

Suborder Halocypridina Skogsberg, 1920

Superfamily Halocypridoidea Dana, 1853

Family Halocyprididae Dana, 1853

Conchoecia Dana, 1849

Conchoecia? sp. 1

Fig. 5D-F

"Conchoecia" GA D 31 - Grosdidier 1979: 8, figs 60a-d.

Genus aff. "Conchoecia" sp. 150 - Rosenfeld \& Raab 1983: 113, fig. 7.10. - Honigstein et al. 1985: figs 6.150, 7.150.

Conchoecia sp. 1 - Andreu-Boussut 1991: 437, figs 1.1-1.3. - Andreu 1992: 296, fig. 1.1.

Conchoecia? sp. Se6 aff. 'C' sp. GA D 31 - Viviers et al. 2000: 414, figs 10-11.

\section{New material examined}

BRAZIL: 1-US-1 well, Laranjeiras Municipality, Sergipe State (depths of 876, 891 and 900 m); Well '1', Laranjeiras Municipality, Sergipe State (depths of 510 to $540 \mathrm{~m}$ ).

\section{Measurements}

Hypotype (LBP 10): carapace: length $=0.63 \mathrm{~mm}$, height $=0.49 \mathrm{~mm}$, width $=0.38 \mathrm{~mm}$. Hypotype (LBP 11): carapace: length $=0.53 \mathrm{~mm}$, height $=0.43 \mathrm{~mm}$.

Fig. 5. [facing page] Ostracods of the Riachuelo Formation, Sergipe-Alagoas Basin, Albian, Brazil. A-C. Cytherella besrineensis (Bischoff, 1964) comb. nov. A. CP-669, right lateral view. B-C. CP-668. B. Left lateral view. C. Dorsal view. - D-F. Conchoecia? sp. 1. D, F. LBP 10. D. Right lateral view. F. Dorsal view. E. LBP 11, left lateral view. - G-I. Cytherelloidea btaterensis Bischoff, 1964. G. CP-671, right lateral view. H. CP-672, left lateral view. I. CP-673, dorsal view. - J. Cytherelloidea aff. globosa Kaye, 1964, CP-756, right lateral view. - K. Cytherella sp. 1, CP-670, lateral view. - L. Bairdoppilata pseudoseptentrionalis Mertens, 1956, CP-676, right lateral view. - M. Bairdoppilata sp. 1, CP-678, right lateral view. - N-P. Bairdoppilata comanchensis (Alexander, 1929) comb. nov., CP-674. N. Left lateral view. O. Right lateral view. P. Dorsal view. - Q-S. Bairdoppilata sp. 2, CP-757. Q. Right lateral view. R. Left lateral view. S. Dorsal view. Scale bars $=100 \mu \mathrm{m}$. 


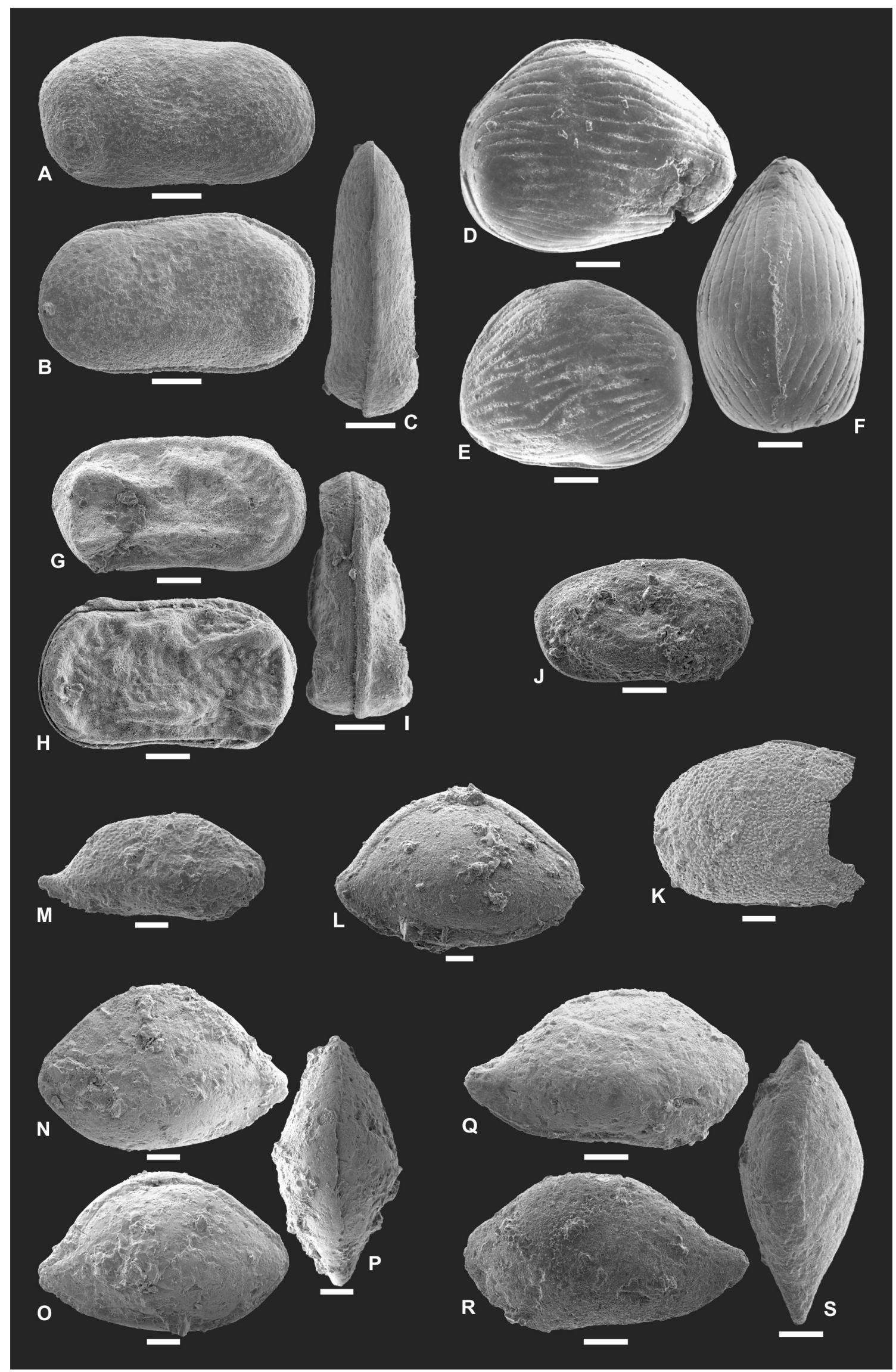




\section{Remarks}

The presence of halocypridids in the Early Cretaceous of the Atlantic Ocean was first noticed by Pokorný (1964), when dealing with ostracods from the Coniacian of Czechoslovakia. Since then, several taxa have been tentatively classified in the genus Conchoecia by several authors (e.g., Colin \& Andreu 1990), although the only morphological resemblance to this Recent genus has to do with the presence of a rostrum (some of the specimens; certainly not the current ones) and striate ornamentation. More detailed studies on the internal features of those specimens have never been performed, and are also not possible with the present material. Therefore, we opt to maintain the current taxonomic status, but doubtfully, in the hope of collecting better preserved specimens in the future.

\section{Paleoecology and distribution}

Conchoecia? sp. 1 is a marine, shelf to neritic, possibly planktonic species occurring in the following localities and stages: Madiéla Formation, Gabon Basin, Gabon, lower-middle Albian (Grosdidier 1979); Talme Yafe, Yavne Shales and Hazera Formations, Levantine Basin, Israel, Albian-lower Cenomanian (Rosenfeld \& Raab 1983); Agadir Basin, Morocco, upper Albian-lower Cenomanian (Andreu-Boussut 1991); and Maruim Member, Riachuelo Formation, Sergipe-Alagoas Basin, Brazil, upper AptianAlbian, Aracajuia benderi zone (MSA-0), Metacytheropteron sp. aff. M. sp. GA C 24 subzone (MSA0.5) (Viviers et al. 2000).

Superorder Podocopomorpha Kozur, 1972

Order Platycopida Sars, 1866

Superfamily Cytherelloidea Sars, 1866

Family Cytherellidae Sars, 1866

Cytherella Jones, 1849

Cytherella besrineensis (Bischoff, 1964) comb. nov.

Fig. 5A-C

Cytherelloidea besrineensis Bischoff, 1964: 15, figs 3.21-3.22.

Cytherelloidea besrineensis - Rosenfeld \& Raab 1983: 92, figs 1.11-1.12. — Honigstein et al. 1985: 3, fig. 3.228.

Cytherella sp. Se3 - Viviers 2000: 415, fig. 8.13.

\section{New material examined}

BRAZIL: Estre outcrop, Rosário do Catete Municipality, Sergipe State (sample MP-1428), approximate coordinates $10^{\circ} 41^{\prime}$ S, $37^{\circ} 02^{\prime}$ W; Massapê outcrop, Riachuelo Municipality, Sergipe State (samples MP1518 and MP-1520), approximate coordinates $10^{\circ} 06^{\prime} \mathrm{S}, 37^{\circ} 10^{\prime} \mathrm{W}$; P384 outcrop, Riachuelo Municipality, Sergipe State (samples MP-1500, MP-1506 and MP-1509 to MP-1513), approximate coordinates $10^{\circ} 43^{\prime}$ S, $37^{\circ} 12^{\prime} \mathrm{W}$; Porto dos Barcos 3 outcrop, Riachuelo Municipality, Sergipe State (samples MP1460, MP-1468 to MP-1472 and MP-1481), approximate coordinates $10^{\circ} 43^{\prime}$ S, 37¹0' W; São José 1 outcrop, Riachuelo Municipality, Sergipe State (samples MP-1558 and MP-1563), approximate coordinates $10^{\circ} 44^{\prime} \mathrm{S}, 37^{\circ} 13^{\prime} \mathrm{W}$.

\section{Type locality and age}

Sample no. 202, Btater Village, Bhamdoun Town, Lebanon; Albian. 


\section{Measurements}

Homeotype (CP-668): , carapace: length $=0.56 \mathrm{~mm}$, height $=0.30 \mathrm{~mm}$, width $=0.20 \mathrm{~mm}$. Homeotype (CP-669): , , right valve: length $=0.55 \mathrm{~mm}$, height $=0.28 \mathrm{~mm}$.

\section{Remarks}

Cytherella besrineensis (Bischoff, 1964) comb. nov. was initially assigned by Bischoff (1964) to the genus Cytherelloidea, although it did not present any ridge on its lateral surface, which is diagnostic of that genus (Alexander 1929). Therefore, we transfer it to Cytherella, based on ornamentation similarities.

\section{Paleoecology and distribution}

Cytherella besrineensis comb. nov. is a marine, shelf species occurring in the following localities and stages: Talme Yafe, Rama, Telamim and Yavne Shales Formations, Levantine Basin, Israel, AptianAlbian (Rosenfeld \& Raab 1983; Honigstein et al. 1985); Levantine Basin, Lebanon, Aptian-Albian (Bischoff 1964); and Angico Member, Riachuelo Formation, Sergipe-Alagoas Basin, Brazil, middle Albian, Praebythoceratina amsittenensis subzone (MSA-0.3) (Viviers et al. 2000); in the present work, also in the Taquari and Maruim Members, uppermost Aptian-Albian, Aracajuia benderi (MSA0) - Sergipella viviersae (MSA-0.2), Praebythoceratina amsittenensis (MSA-0.3) and Reticulocosta edrianae (MSA-0.4) subzones - and Aracajuia antiqua (MSA-1) zones.

\section{Cytherella sp. 1}

Fig. $5 \mathrm{~K}$

\section{Material examined}

BRAZIL: Estre outcrop, Rosário do Catete Municipality, Sergipe State (samples MP-1427 and MP1429), approximate coordinates $10^{\circ} 41^{\prime} \mathrm{S}, 37^{\circ} 02^{\prime} \mathrm{W}$.

\section{Measurements}

Hypotype (CP-670): valve: height $=0.51 \mathrm{~mm}$.

\section{Remarks}

Despite its unusual fine, nodose ornamentation, Cytherella sp. 1 is comparable in overall shape to several Cytherella species with Albian (partly or not) distribution, which justifies its generic attribution. These include Cytherella ovata (Roemer, 1841) (several sedimentary units, ages and locations in Europe, and possibly nearby regions in America, Africa and Asia) (Brown 1957; Herrig 1966; Bassoulet \& Damotte 1969; Swain \& Brown 1972; Majoran 1989; Witte et al. 1992; El-Nady et al. 2008); Cytherella comanchensis Alexander, 1929 (Fort Worth Formation, United States, upper Albian) (Alexander 1929); and Cytherella fredericksburgensis Alexander, 1932 (Goodland Formation, United States, Albian) (Alexander 1932). However, because of the lack of well-preserved specimens in the current samples, it was not possible to provide a more specific identification of them.

\section{Paleoecology and distribution}

Cytherella sp. 1 is a marine, outer shelf species occurring in the Taquari Member, Riachuelo Formation, Sergipe-Alagoas Basin, Brazil, upper Albian (earlier than the Reticulocosta edrianae subzone (MSA0.4)), Aracajuia benderi zone (MSA-0). 
Cytherelloidea Alexander, 1929

Cytherelloidea btaterensis Bischoff, 1964

Fig. 5G-I

Cytherelloidea btaterensis Bischoff, 1964: 17, figs 2.16-2.17, 3.18-3.19.

Cytherelloidea btaterensis - Damotte \& Saint-Marc 1972: 277, fig. 1.2. — Rosenfeld \& Raab 1983: 92, figs 1.14-1.16. - Honigstein et al. 1985: 12, fig. 3.173.

\section{New material examined}

BRAZIL: Fazenda Santa Bárbara outcrop, Rosário do Catete Municipality, Sergipe State (sample MP1420), approximate coordinates $10^{\circ} 39^{\prime} \mathrm{S}, 37^{\circ} 01^{\prime} \mathrm{W}$; Massapê outcrop, Riachuelo Municipality, Sergipe State (samples MP-1515 and MP-1518 to MP-1520), approximate coordinates $10^{\circ} 06^{\prime} \mathrm{S}, 37^{\circ} 10^{\prime} \mathrm{W}$; P384 outcrop, Riachuelo Municipality, Sergipe State (samples MP-1500 and MP-1509 to MP-1513), approximate coordinates $10^{\circ} 43^{\prime} \mathrm{S}, 37^{\circ} 12^{\prime} \mathrm{W}$; Penha outcrop, Riachuelo Municipality, Sergipe State (samples MP-1449, MP-1452, MP-1457 and MP-1459), approximate coordinates $10^{\circ} 42^{\prime} \mathrm{S}, 3^{\circ} 13^{\prime} \mathrm{W}$; Porto dos Barcos 3 outcrop, Riachuelo Municipality, Sergipe State (samples MP-1474 and MP-1477), approximate coordinates $10^{\circ} 43^{\prime} \mathrm{S}, 37^{\circ} 10^{\prime} \mathrm{W}$; São José 1 outcrop, Riachuelo Municipality, Sergipe State (samples MP-1550 to MP-1555, MP-1558, MP-1563 and MP-1565), approximate coordinates $10^{\circ} 44^{\prime} \mathrm{S}, 37^{\circ} 13^{\prime} \mathrm{W}$.

\section{Type locality and age}

Sample no. 211, Btater Village, Bhamdoun Town, Lebanon; Albian.

\section{Measurements}

Homeotype (CP-671): , , right valve: length $=0.58 \mathrm{~mm}$, height $=0.30 \mathrm{~mm}$.

Homeotype (CP-672): , , carapace: length $=0.59 \mathrm{~mm}$, height $=0.32 \mathrm{~mm}$, width $=0.27 \mathrm{~mm}$.

Homeotype (CP-673): , , carapace: length $=0.54 \mathrm{~mm}$, height $=0.30 \mathrm{~mm}$, width $=0.23 \mathrm{~mm}$.

\section{Remarks}

The diagnosis follows Bischoff (1964). Cytherelloidea btaterensis Bischoff, 1964 resembles Cytherelloidea circumvallata Bonnema, 1941 (middle Albian-early Cenomanian of the Netherlands) (Bonnema 1941; Gründel 1966), but the latter has an extra central ridge, which is absent in the former. Cytherelloidea knaptonensis Kay, 1963, from the Albian of Lebanon (Bischoff 1964), can be separated from the present species by its ornamentation, which does not include reticulations and punctuations between the ridges; also, the shape of the posterior ridge is remarkably different, especially along the dorso-posterior margin. A similar species, Cytherelloidea kayei Weaver, 1982 from the middle-late Cenomanian of England (Weaver 1982), has thicker ridges overall.

\section{Paleoecology and distribution}

Cytherelloidea btaterensis is a marine, shelf to neritic species occurring in the following localities and stages: Levantine Basin, Lebanon, Aptian-Albian (Bischoff 1964; Damotte \& Saint-Marc 1972); Tamun, Hidra, Rama, Yakhini, Yavne Shales and Talme Yafe Formations, Levantine Basin, Israel, AptianAlbian (Rosenfeld \& Raab 1983; Honigstein et al. 1985); and in the present work, Angico and Taquari Members, Riachuelo Formation, Sergipe-Alagoas Basin, Brazil, uppermost Aptian-Albian, Aracajuia benderi (MSA-0) - Sergipella viviersae (MSA-0.2), Praebythoceratina amsittenensis (MSA-0.3) and Reticulocosta edrianae (MSA-0.4) subzones - and Aracajuia antiqua (MSA-1) zones. 
Cytherelloidea aff. globosa Kaye, 1964

Fig. 5J

?Cytherelloidea globosa Kaye, 1964: 71, pl. 9, figs 9.7, 9.9-9.10.

Cytherelloidea globosa - ?Weaver 1982: 21, figs 3.20-3.21.

\section{Material examined}

BRAZIL: Estre outcrop, Rosário do Catete Municipality, Sergipe State (samples MP-1422 and MP1428), approximate coordinates $10^{\circ} 41^{\prime} \mathrm{S}, 37^{\circ} 02^{\prime} \mathrm{W}$.

\section{Measurements}

Hypotype (CP-756): right valve: length $=0.51 \mathrm{~mm}$, height $=0.29 \mathrm{~mm}$.

\section{Remarks}

The specimens of Cytherelloidea aff. globosa Kaye, 1964 are similar to those of Cytherella globosa Kaye, 1964, from the Albian-Cenomanian of England (Kaye 1964; Weaver 1982). They differ, though, by a more pronouncedly sloping posterior section of the dorsal margin and the absence of the posteroventral tubercle in right view. It is not clear, however, to which extent these differences are merely morphological or caused by diagenetic processes, considering that the present specimens are poorly preserved.

\section{Paleoecology and distribution}

Cytherelloidea aff. globosa is a marine, outer shelf species that occurs in the Taquari Member, Riachuelo Formation, Sergipe-Alagoas Basin, Brazil, middle Albian, Aracajuia benderi zone (MSA-0), Reticulocosta edrianae subzone (MSA-0.4).

Order Podocopida Sars, 1866

Suborder Bairdiocopina Gründel, 1967

Superfamily Bairdioidea Sars, 1888

Family Bairdiidae Sars, 1888

Subfamily Bairdiinae Sars, 1888

Bairdoppilata Coryell et al., 1935

Bairdoppilata comanchensis (Alexander, 1929) comb. nov.

Fig. 5N-P

Bairdia comanchensis Alexander, 1929: 63, figs 2.15, 3.4.

Bairdia comanchensis - Howe \& Laurencich 1958: 66, unnumbered figs. - Moysey \& Maddocks 1982: 144, figs 1.2a-b, 4.13-4.14.

Bairdia cf. comanchensis - ?Grekoff \& Deroo 1956: 217, figs 46.9-46.10.

Bairdia aff. comanchensis - ?Neufville 1973: 127, fig. 7.4.3a-b. - Reyment 1981: 142, fig. 2a-b.

Bairdia spp. - Rosenfeld \& Raab 1974 pars: 6, fig. 1.14. Honigstein et al. 1985 pars: 3, figs 9.94, 9.94.

Bairdia pseudoseptentrionalis (Mertens, 1956) - Shahin 1991: 136, figs 1.16-1.17.

Bairdoppilata aff. pseudoseptentrionalis - Andreu \& Bilotte 2006: 60, figs 1.15-1.17.

non Bairdia comanchensis - Swain \& Brown 1964: 12, fig. 1.5a-c.

non Bairdia spp. - Rosenfeld \& Raab 1974 pars: 6, figs. 1.15-1.16. 


\section{New material examined}

BRAZIL: 1-US-1 well, Laranjeiras Municipality, Sergipe State (depths of 552, 570, 600, 810, 816 and $840 \mathrm{~m}$ ); Massapê outcrop, Riachuelo Municipality, Sergipe State (samples MP-1514, MP-1516 to MP1520, MP-1522, MP-1542, MP-1543 and MP-1546), approximate coordinates $10^{\circ} 06^{\prime} \mathrm{S}, 37^{\circ} 10^{\prime} \mathrm{W}$.

\section{Type locality and stratum}

"Station 24", Johnson County, Texas, United States; upper Denton Formation, upper Albian.

\section{Measurements}

Hypotype (CP-674): carapace: length $=0.76 \mathrm{~mm}$, height $=0.49 \mathrm{~mm}$, width $=0.38 \mathrm{~mm}$. Hypotype (CP-675): right valve: length $=0.75 \mathrm{~mm}$, height $=0.42 \mathrm{~mm}$.

\section{Remarks}

The new generic identification for Bairdoppilata comanchensis (Alexander, 1929) comb. nov. follows Maddocks (1969) and Becker et al. (1989). According to both, the genus Bairdia McCoy, 1844 (to which the present species was first assigned) is restricted to the Paleozoic period; the former also mentions that Bairdoppilata is virtually identical in external view to Bairdia, but presents a series of denticles ahead of both extremities of its hinge in internal view, and is confined to the Cretaceous-Recent. The present authors rely on both statements for the generic change herein performed. Several occurrences (including possible ones) of Bairdoppilata pseudoseptentrionalis Mertens, 1956 (Shahin 1991; Andreu \& Bilotte 2006) are transferred to Bairdoppilata comanchensis comb. nov. based on differences in size and overall external shape from these specimens to the ones assigned by Mertens (1956). One of the specimens identified as Bairdoppilata comanchensis in Swain \& Brown (1964: pl. 1, fig. 5a, c) belongs in fact to B. rotunda (Alexander, 1929) - see the generic review in Howe \& Laurencich (1958); the other one is from an unnamed taxon. The specimen in Neufville (1973), also figured in Reyment (1981), might belong to $B$. comanchensis comb. nov., despite differences in carapace size and dorsal margin morphology, possibly caused, respectively, by environmental and diagenetic factors. One of the specimens of Bairdia spp. figured in Rosenfeld \& Raab (1974: pl. 1, fig. 14) also belongs to the same species, but these authors do not specify its range and geographical distribution, instead grouping it with all the others identified as Bairdia; this problem was partly solved by Honigstein et al. (1985), who restricted the Bairdoppilata comanchensis specimens to the late Cenomanian-Turonian.

\section{Paleoecology and distribution}

Bairdoppilata comanchensis comb. nov. is a transitional to marine (shelf to neritic) species occurring in the following localities and stages: Denton, Walnut (middle Albian) and Weno (Albian) Formations, United States (Alexander 1929; Howe \& Laurencich 1958; Moysey \& Maddocks 1982); Raha and Abu Qada Formations, Egypt, Cenomanian (Shahin 1991); Marnes de la Fontaine Salée and Grès de las Sals Formations, Aquitaine Basin, France, Cenomanian-Turonian (Andreu \& Bilotte 2006); possibly Ora shale, upper part of the 'En Yorqe'am Member and the Avnon Member, Hazera Formation; Yotvata Member, in the Negba, Moza, Bet Hakerem, Kefar Sha'ul, 'Isfiya, Khureibe and Daliya Formations; Levantine Basin, Israel, upper Cenomanian-Turonian (Rosenfeld \& Raab 1974; Honigstein et al. 1985); and in the present work, Angico, Taquari and Maruim Members, Riachuelo Formation, Sergipe-Alagoas Basin, Brazil, uppermost Albian, Aracajuia antiqua zone (MSA-1).

\section{Bairdoppilata pseudoseptentrionalis Mertens, 1956}

Fig. 5L

Bairdoppilata pseudoseptentrionalis Mertens, 1956: 182, figs 8.7-8.10, 13.89-13.90. 
Bairdoppilata pseudoseptentrionalis - Howe \& Laurencich 1958: 82, unnumbered figs. - Weaver 1982: 24, figs 4.1-4.3. — ?Jarvis et al. 1988: 34, fig. 15j.

Cytherina subdeltoidea Münster, 1830 - ?Roemer 1841: 105, fig. 16.22. - ?Reuss 1845: 54, fig. 5.38.

Cythere (Bairdia) subdeltoidea - Jones 1849 pars: 23, fig. 5.15a-c, e-f.

Bairdia subdeltoidea - ?Jones \& Hinde 1890: 5, figs 2.31-2.34.

Bairdia pseudoseptentrionalis - Oertli 1963: pl. 72, pl. 73, fig. 1, pl. 76. — ?Kaye 1965: 223, figs 2.1, 2.3-2.6. — ?Gründel 1966: 15, fig. 1.18. — ?Keen \& Siddiqui 1971: 63, fig. 1.2. — Hart 1973: 281, fig. 4. — ?Babinot et al. 1985a: 172, fig. 51.1.

Bairdia sp. - Majoran 1989: 9, figs 2.5-2.7.

Bairdoppilata sp. 1 - Piovesan et al. 2013: 244, fig. 3.8a-b.

non Cythere (Bairdia) subdeltoidea - Jones 1849 pars: 23, fig. 5.15d.

non Bairdia pseudoseptentrionalis - El-Nady et al. 2008: 544, fig. 2.6.

non Bairdia gr. pseudoseptentrionalis - Babinot et al. 1985b: 224, figs 55.15-55.16.

\section{New material examined}

BRAZIL: P384 outcrop, Riachuelo Municipality, Sergipe State (MP-1509 to MP-1513), approximate coordinates $10^{\circ} 43^{\prime} \mathrm{S}, 37^{\circ} 12^{\prime} \mathrm{W}$; Porto dos Barcos 3 outcrop, Riachuelo Municipality, Sergipe State (samples MP-1460, MP-1468 and MP-1469), approximate coordinates 1043' S, 37¹0' W; São José 1 outcrop, Riachuelo Municipality, Sergipe State (samples MP-1574, MP-1680 and MP-1697), approximate coordinates $10^{\circ} 44^{\prime} \mathrm{S}, 37^{\circ} 13^{\prime} \mathrm{W}$.

\section{Type locality and stratum}

194 well, Dalum oil field, Germany; Lower Chalk Group, upper Albian.

\section{Measurements}

Homeotype (CP-676): carapace: length $=0.91 \mathrm{~mm}$, height $=0.58 \mathrm{~mm}$, width $=0.44 \mathrm{~mm}$. Homeotype (CP-677): left valve: length $=0.91 \mathrm{~mm}$, height $=0.55 \mathrm{~mm}$.

\section{Remarks}

The diagnosis follows Mertens (1956). Historically, Bairdoppilata pseudoseptentrionalis Mertens, 1956 has been mistaken for B. subdeltoidea (Münster, 1830), as the former species has never been adequately illustrated since its description by Münster (1830). Several sub-species were added to Bairdoppilata subdeltoidea during the $19^{\text {th }}$ century, which increases the difficulties in establishing its current taxonomic status. The most recent review of the species is in Deroo (1956), who renamed it as Bairdoppilata roemeri, with a lower Cretaceous-Tertiary stratigraphic range. Assuming the species is still valid, it has to be separated from Bairdoppilata pseudoseptentrionalis, at least in terms of age; the former is considered later Cretaceous-Tertiary (Münster 1830), while the latter is from the late AlbianCenomanian (Mertens 1956). The specimens in Kaye (1965), Gründel (1966) and Jarvis et al. (1988) present a straighter posterior portion of the dorsal margin in the left valve, when compared to the more rounded one in B. pseudoseptentrionalis. In Keen \& Siddiqui (1971) and Babinot et al. (1985b), the specimens presents a generally wider overlapping and less rounded overall shape.

\section{Paleoecology and distribution}

Bairdoppilata pseudoseptentrionalis is a shelf to neritic marine species occurring in the following localities and stages: Anglo-Paris Basin, France, middle Albian (Oertli 1963); Lower Chalk Group, Germany, Albian-Cenomanian (Mertens 1956); Gault, Greensand and Holywell Nodular Chalk (including Plenus Marl Member) Formations, Anglo-Paris Basin, England, Albian-Cenomanian (Jones 1849; Hart 1973; Weaver 1982); Bordj Ghdir Basin, Algeria, lower Cenomanian (Majoran 1989); 
Florianópolis and Guarujá Formation, Santos Basin, upper Aptian-middle Albian (Piovesan et al. 2013); and in the present work, Angico and Taquari Members, Riachuelo Formation, Sergipe-Alagoas Basin, uppermost Aptian-middle Albian, Aracajuia benderi zone (MSA-0), Sergipella viviersae (MSA-0.2) and Praebythoceratina amsittenensis (MSA-0.3) subzones, Brazil.

\section{Bairdoppilata sp. 1}

Fig. 5M

\section{Material examined}

BRAZIL: Massapê outcrop, Riachuelo Municipality, Sergipe State (samples MP-1516, MP-1518, MP1520, MP-1545 and MP-1546), approximate coordinates $10^{\circ} 06^{\prime} \mathrm{S}, 37^{\circ} 10^{\prime} \mathrm{W}$.

\section{Measurements}

Hypotype (CP-678): right valve: length $=0.69 \mathrm{~mm}$, height $=0.32 \mathrm{~mm}$.

\section{Remarks}

Bairdoppilata sp. 1 is remarkable among Bairdoppilata species of the lower Cretaceous because of the combination of the following features: an elongate overall shape, elongate posterior end, comparable to B. southerhamensis Weaver, 1982 (although this species' carapace displays greater height) (Weaver 1982), and punctuate ornamentation. The current specimens probably represent a new species, but due to the small amount of material (composed solely of valves) recovered, we opt to leave it in open nomenclature.

\section{Paleoecology and distribution}

Bairdoppilata sp. 1 is a marine, shelf species occurring in the Maruim Member, Riachuelo Formation, Sergipe-Alagoas Basin, Brazil, Albian, Aracajuia antiqua zone (MSA-1).

\section{Bairdoppilata sp. 2}

Fig. 5Q-S

\section{Material examined}

BRAZIL: Massapê outcrop, Riachuelo Municipality, Sergipe State (sample MP-1521), approximate coordinates $10^{\circ} 06^{\prime} \mathrm{S}, 37^{\circ} 10^{\prime} \mathrm{W}$.

\section{Measurements}

Hypotype (CP-757): carapace: length $=0.64 \mathrm{~mm}$, height $=0.34 \mathrm{~mm}$, width $=0.29 \mathrm{~mm}$.

Fig. 6. [facing page] Ostracods of the Riachuelo Formation, Sergipe-Alagoas Basin, Albian, Brazil.A. Robsoniella falklandensis Dingle, 1984; CP-733, right lateral view. - B. Cetacella sp. 1; CP-734, right lateral view. - C. Paracypris eniotmetos Nicolaidis \& Piovesan, 2013; CP-679, right lateral view. D. Liasina sp. 1; CP-682, right lateral view. - E. Harbinia crepata Do Carmo et al., 2013; CP-681, right lateral view. - F. Harbinia sinuata? (Krömmelbein \& Weber, 1971); LBP 09, right lateral view. G-J. Praebythoceratina deltalata sp. nov. G. CP-683, right lateral view. H. CP-684, left lateral view. I. CP-759, dorsal view. J. CP-758, dorsal view. - K-M. Praebythoceratina trinodosa (Alexander, 1934) comb. nov. K. CP-691, right lateral view. L. CP-692, left lateral view. M. CP-690, dorsal view. N-P. Praebythoceratina amsittenensis (Andreu-Boussut, 1991) comb. nov. N. CP-687, right lateral view. O. CP-769, left lateral view. P. CP-689, dorsal view. - Q-S. Patellacythere shimonensis (Rosenfeld \& Raab, 1983) comb. nov. Q. CP-685, right lateral view. R. CP-686, left lateral view. S. CP-760, dorsal view. - T. Patellacythere sp. 1; CP-694, right lateral view. - U. Xestoleberis? sp. 1; CP-761, right lateral view. - V. Aracajuia benderi Krömmelbein, 1967; CP-711, right lateral view. Scale bars $=100 \mu \mathrm{m}$. 


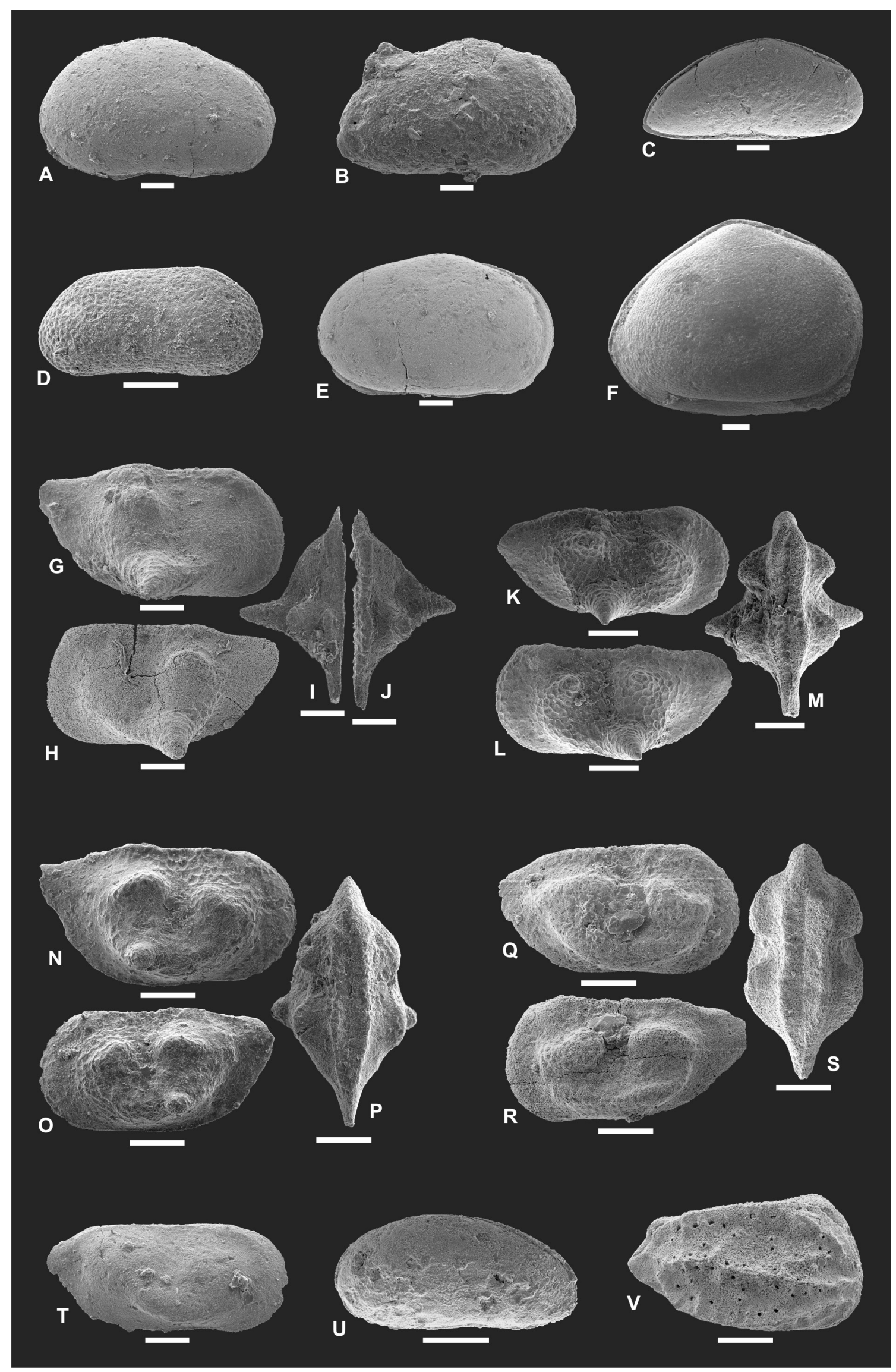




\section{Remarks}

The specimens of Bairdoppilata sp. 2 resemble those of Bairdoppilata sp. 1, although they are less elongate and present a smooth lateral view. Compared to B. southerhamensis in Weaver (1982), it is less rounded in lateral view and narrower than the latter.

\section{Paleoecology and distribution}

Bairdoppilata sp. 2 is a marine, inner shelf species occurring in the Maruim Member, Riachuelo Formation, Sergipe-Alagoas Basin, Brazil, Albian, Aracajuia antiqua zone (MSA-1).

Family Bythocyprididae (Maddocks, 1969)

Robsoniella Kuznetsova, 1956

Robsoniella falklandensis Dingle, 1984

Fig. 6A

Robsoniella falklandensis Dingle, 1984: 118, fig. 8c-f.

Indet sp. A - ?Oertli 1974: 947, figs 6.1-6.11.

Robsoniella cf. falklandensis - ?Damotte 1992: 826, fig. 1.8.

\section{New material examined}

BRAZIL: Porto dos Barcos 3 outcrop, Riachuelo Municipality, Sergipe State (samples MP-1468 and MP-1470), approximate coordinates $10^{\circ} 43^{\prime} \mathrm{S}, 37^{\circ} 10^{\prime} \mathrm{W}$.

\section{Type locality and stratum}

Not designated.

\section{Measurements}

Homeotype (CP-733): right valve: length $=0.72 \mathrm{~mm}$, height $=0.43 \mathrm{~mm}$.

\section{Remarks}

The diagnosis follows Dingle (1984). The genus Robsoniella was originally placed in the family Healdiidae Harlton, 1933 by Kuznetsova (1956). After review by Gramm \& Kuznetsova (1970), it was separated into its own family, Robsoniellidae Gramm \& Kuznetsova, 1970. Dingle (1984) first noted its affiliation to the superfamily Bairdioidea Sars, 1888, despite classifying it as a Bairdiidae Sars, 1888. However, it shares several morphological characters with the Bythocyprididae Maddocks, 1969, as already pointed out by Babinot et al. (2009), although this study gave no further explanation. Bythocyprididae was originally proposed by Maddocks (1969) as a subfamily of Bairdiidae Sars, 1888, namely Bythocypridinae Maddocks, 1969. Its status was reviewed by Kozur (1972), who elevated it to the family level. Specimens in Oertli (1974) and Damotte (1992) present a very similar general layout in lateral view, although not enough to consider them as being Robsoniella falklandensis.

\section{Paleoecology and distribution}

Robsoniella falklandensis Dingle, 1984 is a marine, outer shelf to neritic species occurring in the following localities and stages: Mzinene Formation, South Africa, Cenomanian (Dingle 1984); and in the Taquari Member, Riachuelo Formation, Sergipe-Alagoas Basin, Brazil, middle Albian, Aracajuia benderi zone (MSA-0), Praebythoceratina amsittenensis subzone (MSA-0.3). 
Suborder Cypridocopina Jones, 1901

Superfamily Cypridoidea Baird, 1845

Family Candonidae Kaufmann, 1900

Subfamily Cyclocypridinae Kaufmann, 1900

Cetacella Martin, 1958

\section{Cetacella sp. 1}

Fig. 6B

Cetacella GA D 25 - Grosdidier 1979: 8, fig. 53a-c.

\section{New material examined}

BRAZIL: 1-US-1 well, Laranjeiras Municipality, Sergipe State (depths of 750, 1110 and $1131 \mathrm{~m}$ ); Massapê outcrop, Riachuelo Municipality, Sergipe State (samples MP-1517, MP-1534, MP-1544, MP1545 and MP-1547), approximate coordinates $10^{\circ} 06^{\prime} \mathrm{S}, 37^{\circ} 10^{\prime} \mathrm{W}$.

\section{Measurements}

Hypotype (CP-734): right valve: length $=0.73 \mathrm{~mm}$, height $=0.42 \mathrm{~mm}$.

\section{Remarks}

The generic diagnosis follows Martin (1958). Cetacella GA D 25 in Grosdidier (1979) also belongs to this species.

\section{Paleoecology and distribution}

Cetacella sp. 1 is a marine, shelf species occurring in the following localities and stages: Madiéla Formation, Gabon Basin, Gabon, upper Aptian-lower Albian (Grosdidier 1979). In the present work: Maruim Member, Riachuelo Formation, Sergipe-Alagoas Basin, Brazil, uppermost Aptian-Albian, Aracajuia benderi (MSA-0) - Sergipella viviersae (MSA-0.2) and Metacytheropteron sp. aff. M. sp. GA C 24 (MSA-0.5) subzones - and Aracajuia antiqua (MSA-1) zones.

Subfamily Paracypridinae Sars, 1923

Paracypris Sars, 1866

Paracypris eniotmetos Nicolaidis \& Piovesan, 2013

Fig. 6C

Paracypris eniotmetos Nicolaidis \& Piovesan, 2013: 244, fig. 3.10a-e.

Paracypris aff. mdaouerensis Bassoullet \& Damotte, 1969 - Viviers et al. 2000: 418, figs 10.16, 10.2110.22 .

Paracypris sp. P3 - Viviers et al. 2000: 418, figs 10.10-10.11.

\section{New material examined}

BRAZIL: 1-US-1 well, Laranjeiras Municipality, Sergipe State (depths of 300, 390, 804 and $831 \mathrm{~m}$ ); Estre outcrop, Rosário do Catete Municipality, Sergipe State (sample MP-1423), approximate coordinates $10^{\circ} 41^{\prime} \mathrm{S}, 37^{\circ} 02^{\prime} \mathrm{W}$; Fazenda Santa Bárbara outcrop, Rosário do Catete Municipality, Sergipe

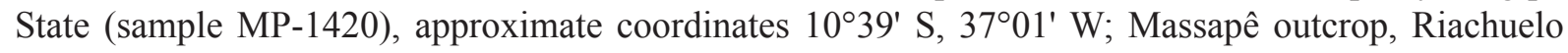
Municipality, Sergipe State (samples MP-1514, MP-1515, MP-1517 to MP-1521, MP-1531 and MP- 
1545 to MP-1547), approximate coordinates $10^{\circ} 06^{\prime} \mathrm{S}, 37^{\circ} 10^{\prime} \mathrm{W}$; P384 outcrop, Riachuelo Municipality, Sergipe State (samples MP-1497, MP-1506 and MP-1511 to MP-1513), approximate coordinates $10^{\circ} 43^{\prime} \mathrm{S}, 37^{\circ} 12^{\prime} \mathrm{W}$; Penha outcrop, Riachuelo Municipality, Sergipe State (samples MP-1449 to MP1453, MP-1456, MP-1457 and MP-1459), approximate coordinates $10^{\circ} 42^{\prime} \mathrm{S}, 37^{\circ} 13^{\prime} \mathrm{W}$; Porto dos Barcos 3 outcrop, Riachuelo Municipality, Sergipe State (samples MP-1460 to MP-1466 and MP-1468 to MP-1472), approximate coordinates $10^{\circ} 43^{\prime}$ S, $37^{\circ} 10^{\prime}$ W; São José 1 outcrop, Riachuelo Municipality, Sergipe State (samples MP-1550 to MP-1555, MP-1557 to MP-1568, MP-1570 to MP-1577, MP-1680 and MP-1695 to MP-1697), approximate coordinates $10^{\circ} 44^{\prime} \mathrm{S}, 37^{\circ} 13^{\prime} \mathrm{W}$.

\section{Type locality and stratum}

PAB-15 well at a depth of 1029 m, Espírito Santo Basin, Espírito Santo State, Brazil; São Mateus Formation, Albian.

\section{Measurements}

Homeotype (CP-679): carapace: length $=0.67 \mathrm{~mm}$, height $=0.30 \mathrm{~mm}$, width $=0.20 \mathrm{~mm}$. Homeotype (CP-680): right valve: length $=0.58 \mathrm{~mm}$, height $=0.24 \mathrm{~mm}$.

\section{Remarks}

The diagnosis follows Piovesan et al. (2013), although no striate forms were observed in the present samples.

\section{Paleoecology and distribution}

Paracypris eniotmetos Nicolaidis \& Piovesan, 2013 is a transitional to marine (shelf) species occurring in the following localities and stages: Potiguar Basin, Jandaíra Formation, Coniacian-Santonian (Viviers et al. 2000); Santos Basin, Florianópolis, Juréia and Itanhaém Formations, Albian-lower Santonian; Espírito Santo Basin, São Mateus Formation, Albian (Piovesan et al. 2013); Sergipe-Alagoas Basin, Angico and Taquari Members, Riachuelo Formation, upper Aptian-Albian, Aracajuia benderi zone (MSA-0), Harbinia sinuata? (MSA-0.1), Praebythoceratina amsittenensis (MSA-0.3) and Reticulocosta edrianae (MSA-0.4) subzones (Viviers et al. 2000); and in the present work, also in the Taquari and Maruim Members, Sergipella viviersae subzone (MSA-0.2) and Aracajuia antiqua zone (MSA-1), Brazil.

Family Quadracyprididae Hou, 2002

Subfamily Quadracypridinae Hou, 2002

Harbinia Tsao, 1959 emend. Hou 1984

Harbinia crepata Do Carmo et al., 2013

Fig. $6 \mathrm{E}$

Harbinia crepata Do Carmo et al., 2013: 95, figs 3.9-3.18.

Gen. ind. sp. aff. 207 - Silva-Telles Júnior \& Viana 1990: 314, figs 2.1, 2.3.

\section{New material examined}

BRAZIL: Estre outcrop, Rosário do Catete Municipality, Sergipe State (sample MP-1423), approximate coordinates $10^{\circ} 41^{\prime} \mathrm{S}, 37^{\circ} 02^{\prime} \mathrm{W}$; São José 1 outcrop, Riachuelo Municipality, Sergipe State (samples MP-1561 and MP-1573), approximate coordinates $10^{\circ} 44^{\prime} \mathrm{S}, 37^{\circ} 13^{\prime} \mathrm{W}$. 


\section{Type locality and stratum}

CE-1 well, at a depth of 2079.5 m, Ceará State, Brazil; Alagamar Formation, Potiguar Basin, middleupper Aptian.

\section{Measurements}

Hypotype (CP-681): right valve: length $=0.72 \mathrm{~mm}$, height $=0.43 \mathrm{~mm}$.

\section{Remarks}

The diagnosis follows Do Carmo et al. (2013).

\section{Paleoecology and distribution}

Harbinia crepata Do Carmo et al., 2013 is a freshwater to shelf species occurring in the following localities and stages: Crato Member, Santana Formation, Araripe Basin, Aptian (Silva-Telles Júnior \& Viana 1990); Alagamar Formation, Potiguar Basin, middle-upper Aptian (Do Carmo et al. 2013); and in the present work, Angico and Taquari Members, Riachuelo Formation, Sergipe-Alagoas Basin, uppermost Aptian-lower Albian, Aracajuia benderi zone (MSA-0), Sergipella viviersae subzone (MSA$0.2)$, Brazil.

Harbinia sinuata? (Krömmelbein \& Weber, 1971) emend. Do Carmo et al. 2013

Fig. $6 \mathrm{~F}$

?Hourcqia angulata sinuata Krömmelbein \& Weber, 1971: 35, fig. 6.24a-c.

Harbinia sinuata - ?Ramos et al. 2006: 344, fig. 4i-1. — ?Do Carmo et al. 2008: 796, fig. 6.10. — ?Do Carmo et al. 2013: 95, figs 4.1-4.24.

Pattersoncypris sinuata - ?Poropat \& Colin 2012: 714, fig. 4.2.

“Cytheridea"? sp. gr. 201/218 - ?Moura \& Praça 1985: 407, figs 2.19, 2.22.

“Cypridea" spp. ex. gr. 201/218 - ?Moura 1988: 1212, figs 2.7, 2.10.

Hourcqia angulata ssp. - ?Silva-Telles Júnior \& Viana 1990: 320, fig. 3.4.

Hourcqia gr. angulata - Colin \& Dépêche 1997: 434, fig. 2.19.

\section{New material examined}

BRAZIL: 1-CPB-1 well, Carmópolis Municipality, Sergipe State (depth of 354.5 m); 7-CP-252 well, Santo Amaro das Brotas Municipality, Sergipe State (depths of 478.45, 478.85, 481.6, 482.9 and $484.4 \mathrm{~m})$.

\section{Measurements}

Homeotype (LBP 9): carapace: length $=0.93 \mathrm{~mm}$, height $=0.76 \mathrm{~mm}$.

\section{Remarks}

The suprageneric taxonomy follows Hou et al. (2002) and the generic one follows Do Carmo et al. (2013). However, although the specimens observed are very similar to Harbinia sinuata (Krömmelbein \& Weber, 1971), they differ in the shape of the dorsal anterior margin adjacent to the "hump" region, characteristic of the genus Harbinia Tsao, 1959. In the specimens of Krömmelbein \& Weber (1971) and Do Carmo et al. (2013), this area of the dorsal margin is flatter, which overall widens the anterior end. The present specimens seem to be similarly, although more discretely, ornamented as other Harbinia species (Krömmelbein \& Weber 1971; Hou 1984; Antonietto et al. 2012; Do Carmo et al. 2013). For these reasons, the current specimens are identified dubiously as Harbinia sinuata. 


\section{Paleoecology and distribution}

Harbinia sinuata? is a freshwater to transitional species occurring in the following localities and stages: Bongor, Doba and Doseo Basins, Chad, upper Aptian (Colin \& Dépêche 1997); and Riachuelo Formation, Sergipe-Alagoas Basin (Krömmelbein \& Weber 1971), Brazil, upper Aptian, Aracajuia benderi zone (MSA-0), Harbinia sinuata? subzone (MSA-0.1).

Superfamily Pontocypridoidea Müller, 1894

Family Pontocyprididae Müller, 1894

Liasina Gramann, 1963

\section{Liasina sp. 1}

Fig. 6D

Bythocypris? sp. Se1 aff. B.? sp. GA C 28 - Viviers et al. 2000: 414, figs 9.8-9.9.

Australoecia sp. 1 - Piovesan et al. 2013: 245, fig. 4.5a-b.

\section{New material examined}

BRAZIL: São José 1 outcrop, Riachuelo Municipality, Sergipe State (sample MP-1552), approximate coordinates $10^{\circ} 44^{\prime} \mathrm{S}, 37^{\circ} 13^{\prime} \mathrm{W}$.

\section{Measurements}

Hypotype (CP-682): right valve: length $=0.41 \mathrm{~mm}$, height $=0.20 \mathrm{~mm}$.

\section{Remarks}

The generic diagnosis follows Gramann (1963). Liasina sp. 1, in contrast to most Liasina species, is not smooth in lateral view, but rather pitted. The very restricted number of specimens does not allow a complete description of this probably new species. Specimens in Viviers et al. (2000), namely Bythocypris? sp. Se1, and Piovesan et al. (2013) also belong to Liasina sp. 1.

\section{Paleoecology and distribution}

Liasina sp. 1 is a marine, shelf species occurring in the following localities and stages: Itanhaém and Itajaí-Açú Formations, Santos Basin, Albian (Piovesan et al. 2013); Angico (Viviers et al. 2000) and Taquari (present work) Members, Riachuelo Formation, Sergipe-Alagoas Basin, uppermost Aptianlower Albian, Aracajuia benderi zone (MSA-0), Sergipella viviersae subzone (MSA-0.2), Brazil.

Suborder Cytherocopina Gründel, 1967

Infraorder Archaeocytherinina Liebau, 1991

Superfamily Bythocytheroidea Sars, 1926

Family Bythocytheridae Sars, 1926

Subfamily Bythocytherinae Sars, 1926

Tribe Bythoceratinini Gründel \& Kozur, 1972

Praebythoceratina Gründel \& Kozur, 1972 emend. Becker, 1990

Praebythoceratina deltalata sp. nov. urn:Isid:zoobank.org:act:AEA6A7C1-F7C3-4BCF-B8CB-3CED348DC62F

Fig. 6G-J

Monoceratina sp. A - ?Donze 1964: 148, fig. 7.145. 


\section{Diagnosis}

A species of Praebythoceratina distinguished by the combination of the following features: ornamentation consisting of irregularly shaped reticulations at the postero-central and ventro-posterior areas, a tubercle in the dorso-central area and an irregularly reticulate spine in the ventro-central area. In dorsal view, the spine presents a widened basis, forming a triangle-shaped ala running from the postero-ventral to the antero-ventral areas.

\section{Etymology}

From the Greek delta, meaning "d", and the Latin alata, meaning "with a wing". Praebythoceratina deltalata sp. nov. presents a spine in its ventro-posterior region that is shaped like a triangular ala (hence delta, as the letter "d" in the Greek alphabet resembles a triangle).

\section{Type Material}

\section{Holotype}

CP-683 (right valve), stored dry in a micropaleontological slide.

\section{Paratypes}

CP-684 (left valve), CP-758 (right valve) and CP-759 (left valve), stored as the holotype.

\section{Other materials examined}

BRAZIL: São José 1 outcrop, Riachuelo Municipality, Sergipe State (samples MP-1551, MP-1552, MP-1554, MP-1558, MP-1559, MP-1561, MP-1564, MP-1565, MP-1567, MP-1568 and MP-1570 to MP-1576), approximate coordinates $10^{\circ} 44^{\prime} \mathrm{S}, 37^{\circ} 13^{\prime} \mathrm{W}$.

\section{Type locality and stratum}

Sample MP-1680, São José 1 outcrop, Riachuelo Municipality, Sergipe-Alagoas Basin, Sergipe State, Brazil, approximate coordinates: $10^{\circ} 44^{\prime} \mathrm{S}, 37^{\circ} 13^{\prime} \mathrm{W}$; Riachuelo Formation, Aracajuia benderi zone (MSA-0), Sergipella viviersae subzone (MSA-0.2), uppermost Aptian-lower Albian.

\section{Measurements}

Holotype (CP-683): right valve: length $=0.56 \mathrm{~mm}$, height $=0.29 \mathrm{~mm}$.

Paratype (CP-684): left valve: length $=0.53 \mathrm{~mm}$, height $=0.29 \mathrm{~mm}$.

Paratype (CP-758): right valve: length $=0.47 \mathrm{~mm}$.

Paratype (CP-759): left valve: length $=0.45 \mathrm{~mm}$, height $=0.23 \mathrm{~mm}$.

\section{Description}

In lateral view, medium-sized subtriangular to sub-rectangular carapace, with greatest height at posterocentral and greatest length at centro-dorsal regions. Round anterior end, becoming slightly rectilinear close to dorsal margin, where an obtuse cardinal angle is formed. Sharp, supra-curvate posterior end, forming dorsal caudal process. Rectilinear dorsal margin, becoming concave only at centro-posterior region. Regularly straight ventral margin, with slight concavity at oral region. Primary ornamentation consisting of tubercle in dorso-central area, irregularly reticulate spine in ventro-central area and highly inconspicuous, large and low marginal rib running from dorso-posterior to antero-ventral margins. Very shallow $\mathrm{S}_{1}$ and $\mathrm{S}_{2}$ sulci. Secondary ornamentation includes irregularly shaped reticulations at posterocentral and ventro-posterior areas. Weakly developed rounded eye tubercle. In dorsal view, strongly sagitiform; spine presents a widened basis, forming wide triangle-shaped ala running from posteroventral to antero-ventral areas. Presence of dorsal ridge creates a flat surface adjacent to hinge line. In internal view, adont hinge, composed in right valve by sulcus running along most of dorsal margin. 
Weakly developed inner lamella, observable along anterior end and ventral region of posterior end; not visible in oral region, where valve margin bends inwards expressively.

\section{Remarks}

Subfamiliar and tribal identifications follow Gründel \& Kozur (1971), while the generic is based on Becker (1990). Occurrences herein described correspond to the first early Cretaceous records of Praebythoceratina Gründel \& Kozur, 1972, hitherto restricted to the Triassic-Jurassic. Most specimens of Praebythoceratina deltalata sp. nov. were found broken, thereby limiting the designation of type specimens. This species is very similar in general layout to Bythoceratina umbonatoides (Kaye, 1964), B. umbonata (Williamson, 1847) and Monoceratina longispina (Bosquet, 1854) from the AlbianCenomanian of England (Kaye 1964, 1965; Weaver 1982). However, they differ in the position of the dorsal tubercle (postero-dorsal in the former, antero-dorsal in the latter) and in the carina-like morphology of the spine basis in $P$. deltalata sp. nov. (absent in B. umbonatoides). Several species, including $P$. amsittenensis (Andreu-Boussut, 1991) comb. nov. from the Albian of Morocco (Andreu-Boussut 1991), B. tamarae Rosenfeld, 1974 and B. avnonensis Rosenfeld, 1974 from the upper Cenomanian of Israel (Rosenfeld \& Raab 1974), are distinguished from P. deltalata sp. nov. by the same features. Donze (1964) illustrated Monoceratina sp. A from the Berriasian of France in dorsal view, which is strongly similar. However, there is not enough information to perform length/height/width measurements of these specimens, and therefore they cannot safely be assumed to belong to P. deltalata sp. nov.

\section{Paleoecology and distribution}

Praebythoceratina deltalata sp. nov. is a marine, shelf species occurring in the Angico and Taquari Members, Riachuelo Formation, Sergipe-Alagoas Basin, Brazil, uppermost Aptian-lower Albian, Aracajuia benderi zone (MSA-0), Sergipella viviersae subzone (MSA-0.2).

Praebythoceratina amsittenensis (Andreu-Boussut, 1991) comb. nov.

Fig. 6N-P

Bythoceratina amsittenensis Andreu-Boussut, 1991: 496, figs 41.6-41.11.

"Patellacythere" GA E 27 - Grosdidier 1979 pars: 8, fig. 51a, c.

Bythoceratina? sp. P1 - ?Viviers et al. 2000: 411, figs 11.12-11.14.

non "Patellacythere" GA E 27 - Grosdidier 1979 pars: 8, fig. 51b.

\section{New material examined}

BRAZIL: 1-CPB-1 well, Carmópolis Municipality, Sergipe State (depths of 345.5, 348 and $348.5 \mathrm{~m}$ ); 7-CP-252 well, Santo Amaro das Brotas Municipality, Sergipe State (depths of 473.8 and $475.3 \mathrm{~m}$ ); Estre outcrop, Rosário do Catete Municipality, Sergipe State (sample MP-1423), approximate coordinates $10^{\circ} 41^{\prime} \mathrm{S}, 37^{\circ} 02^{\prime} \mathrm{W}$; Fazenda Santa Bárbara outcrop, Rosário do Catete Municipality, Sergipe State (sample MP-1420), approximate coordinates $10^{\circ} 39^{\prime} \mathrm{S}, 37^{\circ} 01^{\prime} \mathrm{W}$; P384 outcrop, Riachuelo Municipality, Sergipe State (samples MP-1497, MP-1506, MP-1508 and MP-1510 to MP-1513), approximate coordinates $10^{\circ} 43^{\prime} \mathrm{S}, 37^{\circ} 12^{\prime} \mathrm{W}$; Porto dos Barcos 3 outcrop, Riachuelo Municipality, Sergipe State (samples MP-1460 to MP-1463, MP-1464, MP-1468 to MP-1472, MP-1476, MP-1477 and MP-1481), approximate coordinates $10^{\circ} 43^{\prime} \mathrm{S}, 37^{\circ} 10^{\prime} \mathrm{W}$.

\section{Type locality and stratum}

Samples Am.95, Am.100, Am.105 and Am.110, Jbel Amsittène, Morocco; Oued Tidsi Formation, Albian. 


\section{Measurements}

Homeotype (CP-687): right valve: length $=0.47 \mathrm{~mm}$, height $=0.26 \mathrm{~mm}$.

Homeotype (CP-688): right valve: length $=0.46 \mathrm{~mm}$, height $=0.23 \mathrm{~mm}$.

Homeotype (CP-689): carapace: length $=0.46 \mathrm{~mm}$, height $=0.23 \mathrm{~mm}$, width $=0.22 \mathrm{~mm}$.

Homeotype (CP-769): left valve: length $=0.43 \mathrm{~mm}$, height $=0.23 \mathrm{~mm}$.

\section{Remarks}

The generic identification is based on Becker (1990), while the specific follows Andreu-Boussut (1991). Some of the specimens from the Aptian of Gabon identified by Grosdidier (1979) as "Patellacythere" GA E 27 belong to this species, while others are related to Patellacythere shimonensis (Rosenfeld \& Raab, 1983) comb. nov. Bythoceratina? sp. P1 in Viviers et al. (2000) probably also belongs to the present species, but it is not possible to fully confirm this, as the figured specimen is poorly preserved.

\section{Paleoecology and distribution}

Praebythoceratina amsittenensis comb. nov. is a marine, shelf species occurring in the following localities and stages: Madiéla Formation, Gabon Basin, Gabon, upper Aptian-lower Albian (Grosdidier 1979); Oued Tidsi Formation, Morocco, Albian (Andreu-Boussut 1991); and Taquari Member, Riachuelo Formation, Sergipe-Alagoas Basin, Brazil, uppermost Aptian-middle Albian, Aracajuia benderi zone (MSA-0), Sergipella viviersae (MSA-0.2) and Praebythoceratina amsittenensis (MSA-0.3) subzones.

Praebythoceratina trinodosa (Alexander, 1934) comb. nov. Fig. $6 \mathrm{~K}-\mathrm{M}$

Monoceratina trinodosa Alexander, 1934: p. 64, fig. 8.10.

\section{New material examined}

BRAZIL: São José 1 outcrop, Riachuelo Municipality, Sergipe State (samples MP-1550, MP-1552 to MP-1554, MP-1558, MP-1563 to MP-1565, MP-1571 and MP-1574 to MP-1576), approximate coordinates $10^{\circ} 44^{\prime} \mathrm{S}, 37^{\circ} 13^{\prime} \mathrm{W}$.

\section{Type locality and stratum}

Fort Worth, Texas, United States; Weno Formation, upper Albian.

\section{Measurements}

Homeotype (CP-690): carapace: length $=0.42 \mathrm{~mm}$, height $=0.22 \mathrm{~mm}$, width $=0.22 \mathrm{~mm}$.

Homeotype (CP-691): right valve: length $=0.47 \mathrm{~mm}$, height $=0.25 \mathrm{~mm}$.

Homeotype (CP-692): left valve: length $=0.48 \mathrm{~mm}$, height $=0.22 \mathrm{~mm}$.

Homeotype (CP-693): right valve: length $=0.49 \mathrm{~mm}$, height $=0.24 \mathrm{~mm}$.

\section{Remarks}

The generic identification follows Becker (1990), while the specific follows Alexander (1934). Despite being poorly preserved, the holotype of Praebythoceratina trinodosa (Alexander, 1934) comb. nov. presents typical morphological traits that are not common in other Early Cretaceous bythocytherid species - a postero-dorsal tubercle over the lateral u-shaped inflation and the presence of reticulate ornamentation at the central area that slightly fades along adjacent areas - but observable in the present specimens. Compared to P. amsittenensis comb. nov., P. trinodosa comb. nov. is more slender in lateral view and presents more developed antero-dorsal and postero-dorsal tubercles. 


\section{Paleoecology and distribution}

Praebythoceratina trinodosa comb. nov. is a marine, shelf species occurring in the following localities and stages: United States, upper Albian (Alexander 1934); and in the present work, Angico and Taquari Members, Riachuelo Formation, Sergipe-Alagoas Basin, Brazil, uppermost Aptian-lower Albian, Aracajuia benderi zone (MSA-0), Sergipella viviersae subzone (MSA-0.2).

Tribe Bythocytherini Sars, 1926

Patellacythere Gründel \& Kozur, 1972

Patellacythere shimonensis (Rosenfeld \& Raab, 1983) comb. nov.

Fig. 6Q-S

Monoceratina shimonensis Rosenfeld \& Raab, 1983: 112, figs 7.5-7.7.

Monoceratina shimonensis - Honigstein et al. 1985: 2, fig. 6.159.

"Patellacythere" GA E 27 - Grosdidier 1979: 8, fig. 51b.

'Patellacythere' sp. GA E 27 - Viviers et al. 2000: 427, figs 15.14-15.15.

\section{New material examined}

BRAZIL: Penha outcrop, Riachuelo Municipality, Sergipe State (samples MP-1450 to MP-1453, MP1457 and MP-1459), approximate coordinates $10^{\circ} 42^{\prime}$ S, 37 $13^{\prime}$ W; São José 1 outcrop, Riachuelo Municipality, Sergipe State (samples MP-1550 to MP-1558, MP-1560, MP-1562, MP-1565 to MP1570, MP-1572, MP-1573 and MP-1575), approximate coordinates $10^{\circ} 44^{\prime} \mathrm{S}, 37^{\circ} 13^{\prime} \mathrm{W}$.

\section{Type locality and stratum}

Shimon-1 well, at a depth of 969 m, Israel; Talme Yafe Formation, Levantine Basin, Albian.

\section{Measurements}

Homeotype (CP-685): right valve: length $=0.44 \mathrm{~mm}$, height $=0.23 \mathrm{~mm}$.

Homeotype (CP-686): left valve: length $=0.44 \mathrm{~mm}$, height $=0.22 \mathrm{~mm}$.

Homeotype (CP-760): carapace: length $=0.41 \mathrm{~mm}$, height $=0.21 \mathrm{~mm}$, width $=0.22 \mathrm{~mm}$.

\section{Remarks}

The specific diagnosis follows Rosenfeld \& Raab (1983). The family Bythocytheridae has been thoroughly reviewed by Gründel \& Kozur (1972), Schornikov (1990) and Schornikov \& Mikhailova (1990), who restricted the range of Monoceratina Roth, 1934 to the Devonian-Permian. Therefore, the present authors reassign Patellacythere shimonensis comb. nov. to Patellacythere from Monoceratina Roth, 1928, based on both morphologic and biostratigraphical affinities.

\section{Paleoecology and distribution}

Patellacythere shimonensis comb. nov. is a marine, shelf to neritic species occurring in the following localities and stages: Madiéla Formation, Gabon Basin, Gabon, upper Aptian-lower Albian (Grosdidier 1979); Talme Yafe Formation, Levantine Basin, Israel, Albian (Rosenfeld \& Raab 1983); and Angico Member, Riachuelo Formation, Sergipe-Alagoas Basin, Brazil, uppermost Aptian-lower Albian (Viviers et al. 2000); in the present work, extended to the Taquari Member, although restricted to the Aracajuia benderi zone (MSA-0), Sergipella viviersae subzone (MSA-0.2). 


\section{Patellacythere sp. 1}

Fig. 6T

\section{New material examined}

BRAZIL: Porto dos Barcos 3 outcrop, Riachuelo Municipality, Sergipe State (sample MP-1468).

\section{Measurements}

Hypotype (CP-694): right valve: length $=0.55 \mathrm{~mm}$, height $=0.24 \mathrm{~mm}$.

\section{Remarks}

The only specimen of Patellacythere sp. 1 found in the present samples resembles those of P. parva Weaver, 1982, although not the ones in Witte (1992), which are incomplete, having lost most of their posterior ends. However, Patellacythere sp. 1 has a slightly less developed lateral u-shaped swelling, and therefore is dubiously placed in the current species.

\section{Paleoecology and distribution}

Patellacythere sp. 1 is a marine, inner shelf species occurring in the Taquari Member, Riachuelo Formation, Sergipe-Alagoas Basin, Brazil, middle Albian, Aracajuia benderi zone (MSA-0), Reticulocosta edrianae subzone (MSA-0.4).

\section{Superfamily Xestoleberidoidea Sars, 1928 \\ Family Xestoleberididae Sars, 1928}

Xestoleberis Sars, 1866

Xestoleberis? sp. 1

Fig. $6 \mathrm{U}$

\section{Material examined}

BRAZIL: 1-US-1 well, Laranjeiras Municipality, Sergipe State (depths of 480, 552, 554.5, 1080 and 1086 m); Massapê outcrop, Riachuelo Municipality, Sergipe State (samples MP-1518, MP-1534, MP1544, MP-1545 and MP-1547), approximate coordinates $10^{\circ} 06^{\prime} \mathrm{S}, 37^{\circ} 10^{\prime} \mathrm{W}$.

\section{Measurements}

Hypotype (CP-761): carapace: length $=0.37 \mathrm{~mm}$, height $=0.17 \mathrm{~mm}$.

\section{Remarks}

The present specimens share the typical morphology of Xestoleberis Sars, 1928: a small and smooth carapace, with greatest width at the postero-dorsal region. None of the specimens collected are disarticulated, and thus none of their internal features can be observed. According to Kempf (1986), more than 300 taxa have been described and assigned to this genus, despite its quite conservative shell morphology and the fact that it was originally described based on soft part morphology (Puckett et al. 2012). Many papers describe, identify or partially identify Xestoleberis species in the Cretaceous (Veen 1936; Bonnema 1941; Schmidt 1948; Benson \& Tatro 1964; van den Bold 1964; Holden 1964; Crane 1965; Herrig 1966; Rosenfeld \& Raab 1974; Dingle 1980; Weaver 1982; Damotte \& Fleury 1987; Ismail \& Soliman 1997; Gebhardt 1999; Morsi et al. 2008; Piovesan et al. 2009, 2013; Tesakova 2010; Babinot \& Colin 2011; Puckett et al. 2012). For these reasons, the species observed from the Riachuelo Formation is left in open nomenclature, as Xestoleberis? sp. 1. 


\title{
Paleoecology and distribution
}

Xestoleberis? sp. 1 is a marine, shelf species occurring in the Maruim Member, Riachuelo Formation, Sergipe-Alagoas Basin, Brazil, uppermost Albian, Aracajuia antiqua zone (MSA-1).

\section{Xestoleberis? sp. 2}

Fig. 7A-C

\section{Material examined}

BRAZIL: 1-US-1 well, Laranjeiras Municipality, Sergipe State (depth of $861 \mathrm{~m}$ ); Estre outcrop, Rosário do Catete Municipality, Sergipe State (sample MP-1423), approximate coordinates $10^{\circ} 41^{\prime} \mathrm{S}$, $37^{\circ} 02^{\prime} \mathrm{W}$; Porto dos Barcos 3 outcrop, Riachuelo Municipality, Sergipe State (sample MP-1460), approximate coordinates $10^{\circ} 43^{\prime} \mathrm{S}, 37^{\circ} 10^{\prime} \mathrm{W}$.

\section{Measurements}

Hypotype (CP-697): carapace: length $=0.52 \mathrm{~mm}$, height $=0.28 \mathrm{~mm}$, width $=0.25 \mathrm{~mm}$. Hypotype (CP-735): left valve: length $=0.58 \mathrm{~mm}$, height $=0.30 \mathrm{~mm}$.

\section{Remarks}

For uncertainties in the generic diagnosis, see remarks on Xestoleberis? sp. 1. Xestoleberis? sp. 2 differs from the former by its larger size and sturdier general layout, both in lateral and dorsal views.

\section{Paleoecology and distribution}

Xestoleberis? sp. 2 is a marine, inner shelf species occurring in the Taquari Member, Riachuelo Formation, Sergipe-Alagoas Basin, Brazil, middle Albian, Aracajuia benderi zone (MSA-0), Praebythoceratina amsittenensis subzone (MSA-0.3).

\author{
Infraorder Nomocytherinina Liebau, 1991 \\ Superfamily Cytherideoidea Sars, 1925 \\ Family Cytherideidae Sars, 1925 \\ Subfamily Schulerideinae Mandelstam, 1960 \\ Tribe Schulerideini Mandelstam, 1960
}

Apatocythere Triebel, 1940

$$
\text { Apatocythere? sp. } 1
$$

Fig. 7D-H

\section{Material examined}

BRAZIL: P384 outcrop, Riachuelo Municipality, Sergipe State (samples MP-1511 to MP-1513), approximate coordinates $10^{\circ} 43^{\prime} \mathrm{S}, 37^{\circ} 12^{\prime} \mathrm{W}$.

\section{Measurements}

Hypotype (CP-762): , , carapace: length $=0.60 \mathrm{~mm}$, height $=0.36 \mathrm{~mm}$, width $=0.30 \mathrm{~mm}$. Hypotype (CP-763): $\hat{\lambda}$, carapace: length $=0.66 \mathrm{~mm}$, height $=0.35 \mathrm{~mm}$; width $=0.31 \mathrm{~mm}$.

\section{Remarks}

The suprageneric diagnosis follows Neale (1982). No internal features were observable in the present specimens, although their general shape and size resemble those of Apatocythere species in Triebel (1940). Because of that, the present authors maintain the dubious identification of Apatocythere? sp. 1. 


\section{Paleoecology and distribution}

Apatocythere? sp. 1 is a marine, outer shelf species occurring in the Taquari Member, Riachuelo Formation, Sergipe-Alagoas Basin, Brazil, middle Albian, Aracajuia benderi zone (MSA-0), Praebythoceratina amsittenensis subzone (MSA-0.3).

Family Krithidae Mandelstam, 1960

Subfamily Cuneocytherinae Mandelstam, 1960

Tribe Dicrorygmini Gründel \& Kozur, 1975

\section{Gabonorygma gen. nov. urn:1sid:zoobank.org:act:74466CBB-D7CA-4BA8-9749-533416ECBC34}

\section{Diagnosis}

A genus of Dicrorygmini with the following distinguishing features: sub-rounded to sub-rectangular carapace with rounded, convex dorsal margin, smooth or punctate ornamentation, weakly developed hinge line elements, narrow marginal area and lamellae and valves highly bent inwards in the oral region, sometimes partially obliterating the view of the inner margin and selvage.

\section{Etymology}

From the Latin Gabon, meaning "Gabon", a country where specimens of the genus are common in Early Cretaceous strata; and the Greek orygma, meaning "tunnel", a reference to this genus belonging to the tribe Dicrorygmini Gründel \& Kozur, 1975.

\section{Type species}

Dicrorygma (Orthorygma) brotzeni Christensen, 1965.

\section{Remarks}

The tribal and subfamiliar diagnoses follow Gründel (1978b). The Dicrorygmini is a small tribe probably composed by the following genera: Archeocuneocythere Mandelstam, 1947, Dicrorygma Poag Jr, 1965, Orthorygma Christensen, 1965 (= Oertliana Kilenyi, 1965), here raised to the generic level, and Gabonorygma gen. nov. Species of Gabonorygma gen. nov. so far include G. brotzeni (Christensen, 1965), from the Kimmeridgian-early Tithonian of Denmark, and the presently described G. sergipana gen. et sp. nov. Pattersoncypris? sp. 1 in Piovesan et al. (2013) is also a species to be included in Gabonorygma gen. nov., if properly reviewed. Cytherideinarum gen. et sp. nov. 2 in Oertli et al. (1961), from the Valanginian-Barremian of Denmark, also belongs to this new genus, although it is not officially described; Cytherideinarum itself cannot be accepted as a valid generic name, as it never received a proper diagnosis. Despite the small number of classified taxa, their number could be considerably larger, since Gabonorygma gen. nov. represents what is in general the most neglected carapace morphology among ostracods, namely, a small, rounded, smooth, mostly featureless general layout.

Gabonorygma sergipana gen. et sp. nov. urn:Isid:zoobank.org:act:185D3B61-6920-4DFA-89CA-260C37B43608

Fig. 7I-R

"Asciocythere" GA E 26 - Grosdidier 1979: 8, fig. 58a-c. Ovocytheridea aff. reniformis van den Bold, 1964 - Viviers et al. 2000: 425, figs 14.3-14.4. Pattersoncypris? sp. 1 - Piovesan et al. 2013: 244, fig. 4.3a-b. 


\title{
Diagnosis
}

A species of Gabonorygma gen. nov. distinguished by the following features: carapace with greatest height at the antero-central region and greatest width at the centro-posterior region, round, slightly infra-curvate posterior end and weakly developed inner margin, not visible in the oral region, where the selvage bends inwards expressively.

\section{Etymology}

From Sergipe State, Brazil, where the species was described.

\section{Type material}

\section{Holotype}

BRAZIL: + , carapace, stored dry in a micropaleontological slide (CP-698).

\author{
Allotype

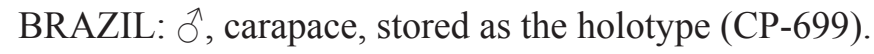

\section{Paratypes} \\ BRAZIL: + , carapace (CP-700), + , carapace (CP-701), + , valve (CP-702) and $\hat{\rho}$, carapace (CP-703); \\ stored as the holotype.
}

\section{Other material examined}

BRAZIL: 1-US-1 well, Laranjeiras Municipality, Sergipe State (depths of 399, 450, 1011, 1020 and 1080 m); 7-CP-252 well, Santo Amaro das Brotas Municipality, Sergipe State (depth of 512.7 m); Fazenda Santa Bárbara outcrop, Rosário do Catete Municipality, Sergipe State (sample MP-1419), approximate coordinates $10^{\circ} 39^{\prime} \mathrm{S}, 37^{\circ} 01^{\prime} \mathrm{W}$; Penha outcrop, Riachuelo Municipality, Sergipe State (samples MP-1450 to MP-1452 and MP-1459), approximate coordinates $10^{\circ} 42^{\prime} \mathrm{S}, 37^{\circ} 13^{\prime} \mathrm{W}$; Porto dos Barcos 3 outcrop, Riachuelo Municipality, Sergipe State (samples MP-1460, MP-1461, MP-1463, MP-1465 and MP-1468 to MP-1472), approximate coordinates $10^{\circ} 43^{\prime}$ S, 37 $7^{\circ} 10^{\prime}$ W; São José 1 outcrop, Riachuelo Municipality, Sergipe State (samples MP-1550 to MP-1565), approximate coordinates $10^{\circ} 44^{\prime} \mathrm{S}, 37^{\circ} 13^{\prime} \mathrm{W}$.

\section{Type locality and stratum}

Sample MP-1472, Porto dos Barcos 3 outcrop, Riachuelo Municipality, Sergipe State, Brazil, approximate coordinates: $10^{\circ} 43^{\prime} \mathrm{S}, 37^{\circ} 10^{\prime} \mathrm{W}$; Riachuelo Formation, Sergipe-Alagoas Basin, middle Albian, Aracajuia benderi zone (MSA-0), Praebythoceratina amsittenensis subzone (MSA-0.3).

Fig. 7. [facing page] Ostracods of the Riachuelo Formation, Sergipe-Alagoas Basin, Albian, Brazil. A-C. Xestoleberis? sp. 2; CP-697. A. Right lateral view. B. Left lateral view. C. Dorsal view. D-H. Apatocythere? sp. 1. D-E. CP-763. D. Right lateral view. E. Dorsal view. F-H. CP-762. F. Right lateral view. G. Left lateral view. H. Dorsal view. - I-R. Gabonorygma sergipana gen. et sp. nov. I. CP-698, right lateral view. J. CP-700, left lateral view. K. CP-701, dorsal view. L. CP-703, dorsal view. M. CP-699, right lateral view. N-R. CP-702. N. Left internal view. O. Detail of the hinge. P. Interpretation of the hinge structures. Q. Detail of the central and anterior muscle scars. R. Interpretation of the central and anterior muscle scars. - S. Aracajuia fragilis (Piovesan \& Nicolaidis, 2013) comb. nov.; CP-764, left lateral view. - T. Microceratina? sp. 1; CP-714, left lateral view. - U. Algeriana? sp. 1; CP-727, left lateral view. Scale bars $=100 \mu \mathrm{m}$. 


\section{ANTONIETTO L.S. et al., Brazilian latest Aptian-Albian marine ostracods}

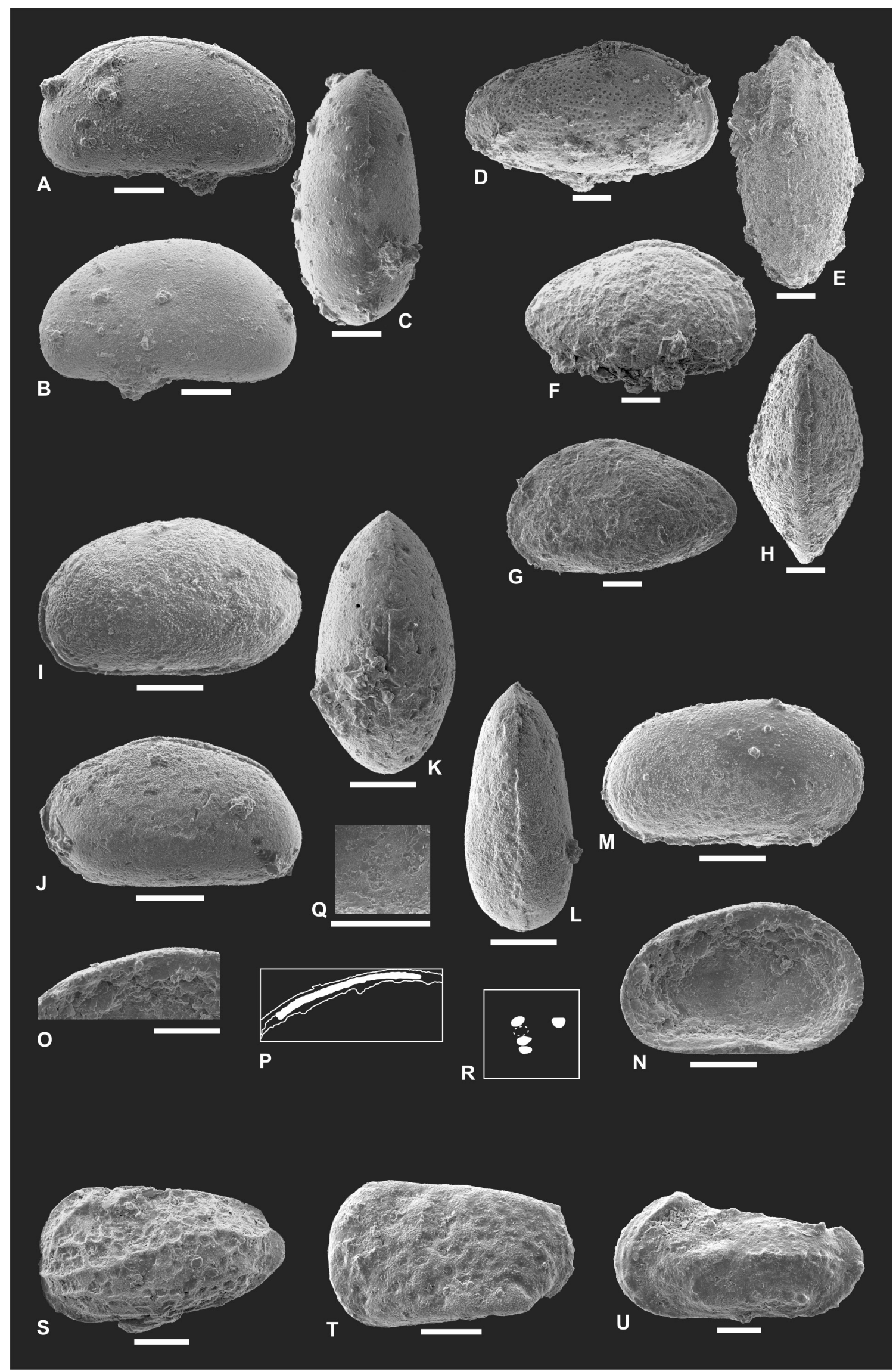




\section{Measurements}

Holotype (CP-698): $q$, carapace: length $=0.40 \mathrm{~mm}$, height $=0.23 \mathrm{~mm}$, width $=0.21 \mathrm{~mm}$. Allotype (CP-699): 0 , carapace: length $=0.40 \mathrm{~mm}$, height $=0.22 \mathrm{~mm}$, width $=0.17 \mathrm{~mm}$. Paratype (CP-700): , , carapace: length $=0.38 \mathrm{~mm}$, height $=0.22 \mathrm{~mm}$, width $=0.20 \mathrm{~mm}$. Paratype (CP-701): 웅, carapace: length $=0.40 \mathrm{~mm}$, height $=0.23 \mathrm{~mm}$, width $=0.21 \mathrm{~mm}$. Paratype (CP-702): , left valve: length $=0.37 \mathrm{~mm}$, height $=0.22 \mathrm{~mm}$.

Paratype (CP-703): $\hat{\sigma}^{\text {, }}$, carapace: length $=0.38 \mathrm{~mm}$, height $=0.20 \mathrm{~mm}$, width $=0.17 \mathrm{~mm}$.

\section{Description}

In lateral view, sub-rounded to sub-rectangular carapace, with greatest height at antero-central and greatest length at central regions. Left valve larger than the right, slightly overlapping it at ventral margin and posterior end. Round anterior end, becoming slightly rectilinear close to dorsal margin, forming an obtuse cardinal angle. Round, slightly infra-curvate posterior end; obtuse posterior cardinal angle. Slightly rectilinear to concave dorsal margin. Rectilinear ventral margin. Smooth overall ornamentation. In dorsal view, elliptical, with greatest width at centro-posterior region. In internal view, adont hinge, composed of smooth bar in left valve. Weakly developed inner lamella, not visible in oral region, where valve margin bends inwards expressively. Selvage visible through entire free margin. Central muscle scar group consisting of at least three elliptical central scars oriented in its greatest axis from anteroventral to postero-dorsal margins and an elliptical frontal scar. Weak sexual dimorphism: females more sub-rounded and wider in dorsal view, males more sub-rectangular and narrower.

\section{Remarks}

Gabonorygma sergipana gen. et sp. nov. can be separated from Gabonorygma brotzeni by the more rounded shape of its posterior end, the more anterior position of its greatest height and the more central position of its greatest width. Specimens in Grosdidier et al. (1979), Piovesan et al. (2013) and Viviers et al. (2000) also belong to the new species.

\section{Paleoecology and distribution}

Gabonorygma sergipana gen. et sp. nov. is a marine, shelf species occurring in the following localities and stages: Madiéla Formation, Gabon Basin, Gabon, lower-middle Albian (Grosdidier 1979). Angico (Viviers et al. 2000) and Taquari (present work) Members, Riachuelo Formation, Sergipe-Alagoas Basin, uppermost Aptian-Albian, Aracajuia benderi (MSA-0) and Aracajuia antiqua (MSA-1) zones, Brazil.

Family Progonocytheridae Sylvester-Bradley, 1948

Subfamily Progonocytherinae Sylvester-Bradley, 1948

Tribe Majungaellini Krömmelbein, 1974

Neocythere Mertens, 1956

Neocythere? aff. pseudovanveeni Gründel, 1966

Fig. 8A-B

?Neocythere pseudovanveeni Gründel, 1966: 33, figs 6.1-6.2.

Neocythere (n. subgen.?) pseudovanveeni - ?Gründel 1967: 638, figs 2.14-2.15.

Neocythere GA B 21 - Grosdidier 1979: 8, fig. 38a-c.

Perissocytheridea? sp. 1 - Piovesan et al. 2013: 240, fig. 5.4a-b. 


\section{New material examined}

BRAZIL: 1-CPB-1 well, Carmópolis Municipality, Sergipe State (depth of 222 m); Massapê outcrop, Riachuelo Municipality, Sergipe State (samples MP-1514, MP-1515, MP-1517 to MP-1522, MP1534, MP-1538, MP-1541, MP-1543, and MP-1545 to MP-1547), approximate coordinates $10^{\circ} 06^{\prime} \mathrm{S}$, $37^{\circ} 10^{\prime} \mathrm{W}$.

\section{Type locality and age}

Camin 3/55 well, Germany; upper Albian.

\section{Measurements}

Homeotype (CP-705): right valve: length $=0.48 \mathrm{~mm}$, height $=0.30 \mathrm{~mm}$.

Homeotype (CP-706): left valve: length $=0.49 \mathrm{~mm}$, height $=0.28 \mathrm{~mm}$.

\section{Remarks}

The suprageneric diagnosis follows Gründel (1977) and Liebau (2005), while the specific diagnosis is based on Gründel (1966). Although the present species and Neocythere? pseudovanveeni Gründel, 1966 are similar in size and general layout, the style of ornamentation and lack of distinctive morphological traits, i.e., the dorsal marginal flange and the pair of ventral ribs, leave the attribution to the former uncertain. Specimens identified as Neocythere GA B 21 in Grosdidier (1979) and Perissocytheridea? sp. 1 in Piovesan et al. (2013) also belong to Neocythere? aff. pseudovanveeni.

\section{Paleoecology and distribution}

Neocythere? aff. pseudovanveeni is a marine, shelf species occurring in the following localities and stages: Germany, upper Albian-lower Cenomanian (Gründel 1966, 1967); Madiéla Formation, Gabon Basin, Gabon, upper Albian-Cenomanian (Grosdidier 1979); Guarujá Formation, Santos Basin, lowermiddle Albian (Piovesan et al. 2013); and in the present work, Maruim Member, Riachuelo Formation, Sergipe-Alagoas Basin, uppermost Albian, Aracajuia antiqua zone (MSA-1), Brazil.

Neocythere (Physocythere) tenuis Kaye, 1965

Fig. 8C-D

Neocythere (Physocythere) tenuis Kaye, 1965: 245, figs 6.14-6.17.

Neocythere (Physocythere) tenuis - Neale 1978: 352, fig. 10.10.

Neocythere sp. GA B 21 - Viviers et al. 2000: 427, figs 15.20-15.22.

\section{New material examined}

BRAZIL: Estre outcrop, Rosário do Catete Municipality, Sergipe State (samples MP-1423, MP-1426 and MP-1429), approximate coordinates $10^{\circ} 41^{\prime} \mathrm{S}, 37^{\circ} 02^{\prime} \mathrm{W}$.

\section{Type locality and stratum}

Henfield, Sussex, England; lower Gault Formation, Hoplites dentatus zone, Anahoplites intermedius subzone, middle Albian.

\section{Measurements}

Homeotype (CP-707): right valve: length $=0.43 \mathrm{~mm}$, height $=0.25 \mathrm{~mm}$. Homeotype (CP-708): left valve: length $=0.44 \mathrm{~mm}$, height $=0.24 \mathrm{~mm}$. 


\section{Remarks}

The specific diagnosis follows Kaye (1965). Neocythere (Physocythere) tenuis Kaye, 1965 is the same species identified by Viviers et al. (2000) as Neocythere sp. GA B 21 from Grosdidier (1979). However, the species in the latter work is, actually, Neocythere? aff. pseudovanveeni (Gründel 1966).

\section{Paleoecology and distribution}

Neocythere (Physocythere) tenuis is a marine, shelf species occurring in the following localities and stages: England, middle Albian (Kaye 1965; Neale 1978); Açu Formation, Potiguar Basin, upper Albianlower Cenomanian; Maruim Member (Viviers et al. 2000); and in the present work, Taquari Member, Riachuelo Formation, Sergipe-Alagoas Basin, middle Albian, Aracajuia benderi zone (MSA-0), Praebythoceratina amsittenensis subzone (MSA-0.3), Brazil.

Superfamily Cytheroidea Baird, 1850

Family Cytheridae Baird, 1850

Subfamily Schizocytherinae Mandelstam, 1960

Tribe Schizocytherini Mandelstam, 1960

Aracajuia Krömmelbein, 1967

Aracajuia antiqua (Rosenfeld \& Raab, 1983) comb. nov.

Fig. $8 \mathrm{G}-\mathrm{I}$

Amphicytherura antiqua Rosenfeld \& Raab, 1983: 96, figs 2.1-2.2.

\section{New material examined}

BRAZIL: 1-US-1 well, Laranjeiras Municipality, Sergipe State (depths of 480, 510, 555 and 1140 m); Massapê outcrop, Riachuelo Municipality, Sergipe State (samples MP-1515 to MP-1522, MP-1530, MP-1534, MP-1538, MP-1540 to MP-1543, MP-1546 and MP-1547), approximate coordinates $10^{\circ} 06^{\prime} \mathrm{S}, 37^{\circ} 10^{\prime} \mathrm{W}$.

\section{Type locality and stratum}

Kokhav-3 well, at a depth of 1454 m, Israel; Telamim Formation, Levantine Basin, Aptian.

\section{Measurements}

Homeotype (CP-709): $q$, left valve: length $=0.51 \mathrm{~mm}$, height $=0.32 \mathrm{~mm}$.

Homeotype (CP-710): $\hat{\jmath}$, carapace: length $=0.50 \mathrm{~mm}$, height $=0.26 \mathrm{~mm}$, width $=0.24 \mathrm{~mm}$.

Fig. 8. [facing page] Ostracods of the Riachuelo Formation, Sergipe-Alagoas Basin, Albian, Brazil. A-B. Neocythere? aff. pseudovanveeni (Gründel, 1966). A. CP-705, right lateral view. B. CP-706, left lateral view. - C-D. Neocythere (Physocythere) tenuis Kaye, 1965. C. CP-707, right lateral view. D. CP-708, left lateral view. - E-F. Quasihermanites? sp. 1. E. CP-766, right lateral view. F. CP-715, left lateral view. - G-I. Aracajuia antiqua (Rosenfeld \& Raab, 1983) comb. nov. G, I. CP-709. G. Right lateral view. I. Dorsal view. H. CP-710, left lateral view. - J-L. Eocytheropteron sp. 1; CP-765. J. Right lateral view. K. Left lateral view. L. Dorsal view. - M-O. Metacytheropteron aff. minuta (Swain, 1976); CP 712. M. Right lateral view. N. Left lateral view. O. Dorsal view. - P-R. Microceratina azazoulensis Andreu \& Colin, 2005; CP-713. P. Right lateral view. Q. Left lateral view. R. Dorsal view. Scale bars $=100 \mu \mathrm{m}$. 


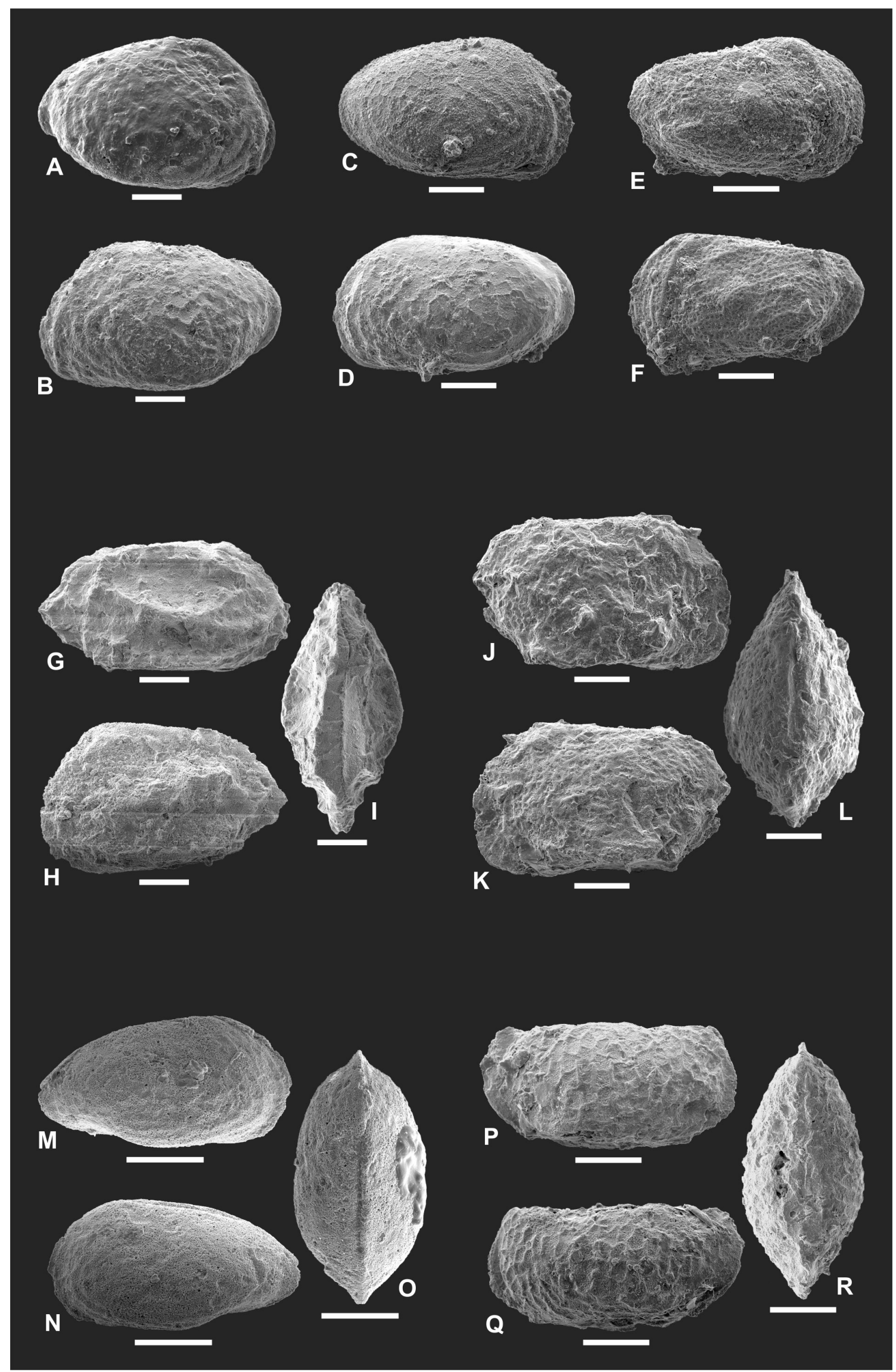




\section{Remarks}

The diagnosis follows Antonietto et al. (2013) for the generic and Rosenfeld \& Raab (1983) for the specific level.

\section{Paleoecology and distribution}

Aracajuia antiqua (Rosenfeld \& Raab, 1983) comb. nov. is a marine, shelf species occurring in the following localities and stages: Telamim and Talme Yafe Formations, Levantine Basin, Israel, AptianAlbian (Rosenfeld \& Raab 1983); and in the present work, Maruim Member, Riachuelo Formation, Sergipe-Alagoas Basin, Brazil, uppermost Albian, Aracajuia antiqua zone (MSA-1).

\section{Aracajuia benderi Krömmelbein, 1967}

Fig. 6V

Aracajuia benderi Krömmelbein, 1967: 529, figs 1, 2a-b, 3, 4a-c.

Aracajuia benderi - Musacchio \& Simeoni 2008: 252, fig. 8. - Antonietto et al. 2013: 7, fig. 6a-r.

Ostracoda sp. B - Krömmelbein 1966: 121, fig. 2a-c.

Amphicytherura aff. benderi - ?Viviers et al. 2000: 427, figs 16.4-16.6.

Amphicytherura benderi - Viviers et al. 2000: 413, figs 16.1-16.3.

Amphicytherura sp. P3 - Viviers et al. 2000: 411, figs 16.11-16.14.

Amphicytherura sp. P4 - ?Viviers et al. 2000: 411, figs 16.15-16.17.

\section{New material examined}

BRAZIL: 1-US-1 well, Laranjeiras Municipality, Sergipe State (depths of 690, 711, 720, 726, 741, 831 and $1161 \mathrm{~m}$ ); 7-CP-252 well, Santo Amaro das Brotas Municipality, Sergipe State (depth of $493 \mathrm{~m}$ ); Estre outcrop, Rosário do Catete Municipality, Sergipe State (sample MP-1423), approximate coordinates $10^{\circ} 41^{\prime} \mathrm{S}, 37^{\circ} 02^{\prime} \mathrm{W}$; Fazenda Santa Bárbara outcrop, Rosário do Catete Municipality, Sergipe State (samples MP-1419, MP-1420), approximate coordinates $10^{\circ} 39^{\prime} \mathrm{S}, 37^{\circ} 01^{\prime} \mathrm{W}$; P384 outcrop, Riachuelo Municipality, Sergipe State (samples MP-1496, MP-1497, MP-1500, MP-1504 and MP-1506 to MP1513), approximate coordinates $10^{\circ} 43^{\prime} \mathrm{S}, 37^{\circ} 12^{\prime} \mathrm{W}$; Penha outcrop, Riachuelo Municipality, Sergipe State (samples MP-1449 to MP-1453 and MP-1455 to MP-1457), approximate coordinates $10^{\circ} 42^{\prime} \mathrm{S}$, $37^{\circ} 13^{\prime} \mathrm{W}$; Porto dos Barcos 3 outcrop, Riachuelo Municipality, Sergipe State (samples MP-1460 to MP1466, MP-1468 to MP-1472, MP-1474 to MP-1477, MP-1481 and MP-1482), approximate coordinates $10^{\circ} 43^{\prime}$ S, 37¹0' W; São José 1 outcrop, Riachuelo Municipality, Sergipe State (samples MP-1550 to MP-1561, MP-1563 to MP-1578, MP-1680 and MP-1694 to MP-1698), approximate coordinates $10^{\circ} 44^{\prime} \mathrm{S}, 37^{\circ} 13^{\prime} \mathrm{W}$.

\section{Type locality and stratum}

Divina Pastora Municipality, Sergipe State, Brazil; Riachuelo Formation, Sergipe-Alagoas Basin, Albian.

\section{Measurements}

Homeotype (CP-711): + , carapace: length $=0.43 \mathrm{~mm}$, height $=0.24 \mathrm{~mm}$, width $=0.20 \mathrm{~mm}$.

\section{Remarks}

The diagnosis follows Antonietto et al. (2013). 


\section{Paleoecology and distribution}

Aracajuia benderi Krömmelbein, 1967 is a marine, shelf species occurring in the following localities and stages: Madiéla Formation, Gabon Basin, Upper Aptian-lower Albian, Gabon (Krömmelbein 1966; Bertels 1977); Potiguar Basin, Açu Formation, middle Albian (Viviers et al. 2000); and Angico Member, Riachuelo Formation, Sergipe-Alagoas Basin, uppermost Aptian-upper Albian, Aracajuia benderi zone (MSA-0) (Krömmelbein 1967; Bertels 1977; Viviers et al. 2000; Musacchio \& Simeoni 2008; Antonietto et al. 2013); in the present work, in addition to the Angico Member, it was also found in the Taquari Member, Brazil.

Aracajuia fragilis (Piovesan \& Nicolaidis, 2013) comb. nov.

Fig. $7 \mathrm{~S}$

Amphicytherura fragilis Piovesan \& Nicolaidis, 2013: 247, fig. 4.7a-d.

\section{New material examined}

BRAZIL: Estre outcrop, Rosário do Catete Municipality, Sergipe State (samples MP-1424 to MP-1431), approximate coordinates $10^{\circ} 41^{\prime} \mathrm{S}, 37^{\circ} 02^{\prime} \mathrm{W}$.

\section{Type locality and stratum}

PAB-15 well at a depth of 1029 m, Espírito Santo State, Brazil; São Mateus Formation, Espírito Santo Basin, Albian.

\section{Measurements}

Homeotype (CP-764): + , left valve: length $=0.45 \mathrm{~mm}$, height $=0.24 \mathrm{~mm}$.

\section{Remarks}

The diagnosis follows Piovesan et al. (2013). After a major review of the genera Amphicytherura and Aracajuia by Antonietto et al. (2013), the species has been transferred to the latter.

\section{Paleoecology and distribution}

Aracajuia fragilis (Piovesan \& Nicolaidis, 2013) comb. nov. is a transitional to marine (shelf) species occurring in the following localities and stages: São Mateus Formation, Espírito Santo Basin, Albian (Piovesan et al. 2013); and in the present work, Taquari Member, Riachuelo Formation, Sergipe-Alagoas Basin, middle Albian, Aracajuia benderi zone (MSA-0), Reticulocosta edrianae subzone (MSA-0.4), Brazil.

Family Cytheruridae Müller, 1894

Subfamily Cytherurinae Müller, 1894

Tribe Eocytheropterini Mandelstam, 1960

Eocytheropteron Alexander, 1933

\section{Eocytheropteron sp. 1}

Fig. 8J-L

\section{Material examined}

BRAZIL: 1-US-1 well, Laranjeiras Municipality, Sergipe State (depths of 996 and 1080 m); Massapê outcrop, Riachuelo Municipality, Sergipe State (samples MP-1515, MP-1516, MP-1518, MP-1519, MP1521, MP-1540, MP-1542, MP-1545 and MP-1547), approximate coordinates $10^{\circ} 06^{\prime} \mathrm{S}, 37^{\circ} 10^{\prime} \mathrm{W}$. 


\section{Measurements}

Hypotype (CP-765): carapace: length $=0.47 \mathrm{~mm}$, height $=0.27 \mathrm{~mm}$, width $=0.21 \mathrm{~mm}$.

Hypotype (CP-767): left valve: length $=0.43 \mathrm{~mm}$, height $=0.23 \mathrm{~mm}$.

\section{Remarks}

The generic diagnosis follows Alexander (1933) and the suprageneric diagnosis follows Gründel (1976). Due to the paucity of well-preserved specimens, Eocytheropteron sp. 1 cannot be properly described.

\section{Paleoecology and distribution}

Eocytheropteron sp. 1 is a marine, shelf species occurring in the Angico, Maruim and Taquari Members, Riachuelo Formation, Sergipe-Alagoas Basin, Brazil, uppermost Aptian-Albian, Aracajuia benderi (MSA-0) - Sergipella viviersae subzone (MSA-0.2) - and Aracajuia antiqua (MSA-1) zones.

Metacytheropteron Oertli, 1957

\section{Metacytheropteron aff. minuta (Swain, 1976)}

Fig. $8 \mathrm{M}-\mathrm{O}$

?Majungaella minuta Swain, 1976: 747, figs 1.19-1.21, 1.23.

Eocytheropteron? sp. - ?Swain 1976: 745, fig. 2.14.

Metacytheropteron GA B 14 - Grosdidier 1979: 8, fig. 40a-c.

Metacytheropteron aff. sp. GA C 26 - Viviers et al. 2000: 414, fig. 15.9.

\section{New material examined}

BRAZIL: São José 1 outcrop, Riachuelo Municipality, Sergipe State (sample MP-1557), approximate coordinates $10^{\circ} 44^{\prime} \mathrm{S}, 37^{\circ} 13^{\prime} \mathrm{W}$.

\section{Measurements}

Hypotype (CP-712): carapace: length $=0.33 \mathrm{~mm}$, height $=0.17 \mathrm{~mm}$, width $=0.16 \mathrm{~mm}$.

\section{Remarks}

The generic diagnosis follows Oertli (1957) and the suprageneric diagnosis follows Gründel (1976). The reclassification of Metacytheropteron minuta (Swain, 1976) has been suggested by several previous works, including Babinot \& Colin (1988) and Piovesan et al. (2012), so the present authors have opted to perform it. The figured specimen possibly belongs to this species, although it differs significantly in the dorsal overlap (strong in Metacytheropteron minuta). Still, it is co-specific with the ones identified as Metacytheropteron GA B 14 by Grosdidier (1979) and Metacytheropteron aff. sp. GA C 26 by Viviers et al. (2000).

\section{Paleoecology and distribution}

Metacytheropteron aff. minuta (Swain, 1976) is a marine, shelf species occurring in the following localities and stages: Madiéla Formation, Gabon Basin, Gabon, Albian (Grosdidier 1979); and Maruim Member, Riachuelo Formation, Sergipe-Alagoas Basin, Brazil, upper Albian, Aracajuia benderi zone (MSA-0), Metacytheropteron sp. aff. sp. GA C 24 subzone (MSA-0.5) (Viviers et al. 2000); in the present work, expanded to the Angico Member, upper Aptian-lower Albian, Sergipella viviersae subzone (MSA-0.2). 
ANTONIETTO L.S. et al., Brazilian latest Aptian-Albian marine ostracods

Subfamily Eucytherurinae Puri, 1974 emend. Maddocks \& Steineck, 1987

Microceratina Swanson, 1980

Microceratina azazoulensis Andreu \& Colin, 2005

Fig. 8P-R

Microceratina azazoulensis Andreu \& Colin, 2005: 21, figs 2.2-2.8.

Chapmanicythereis? sp. 1 - ?Hart \& Critenden 1985: 228, fig. 9d.

Pseudomonoceratina sp. 1 - Andreu-Boussut 1991: 502, fig. 42.3.

Pseudomonoceratina sp. 3 - Andreu-Boussut 1991: 503, figs 42.5-42.6.

Microceratina sp. - Babinot et al. 2009: 7, figs 1.23, 1.23a.

\section{Material examined}

BRAZIL: Massapê outcrop, Riachuelo Municipality, Sergipe State (sample MP-1520), approximate coordinates $10^{\circ} 06^{\prime} \mathrm{S}, 37^{\circ} 10^{\prime} \mathrm{W}$; Porto dos Barcos 3 outcrop, Riachuelo Municipality, Sergipe State (samples MP-1460 and MP-1470), approximate coordinates $10^{\circ} 43^{\prime} \mathrm{S}, 37^{\circ} 10^{\prime} \mathrm{W}$.

\section{Type locality and stratum}

Tarhzoute ( $9^{\circ} 44^{\prime} 50^{\prime \prime}$ W, 30³4'50.3" N), Morocco; Aït Lamine Formation; Azazoul Basin, middle-upper Cenomanian.

\section{Measurements}

Hypotype (CP-713): carapace: length $=0.39 \mathrm{~mm}$, height $=0.18 \mathrm{~mm}$, width $=0.19 \mathrm{~mm}$.

\section{Remarks}

The diagnosis follows Colin et al. (2005). Additionally, Microceratina sp. in Babinot et al. (2009) is included in the synonymic list of Microceratina azazoulensis Andreu \& Colin, 2005. Chapmanicythereis? sp. 1 in Hart \& Critenden (1985) is also tentatively herein considered co-specific, as the figured specimen presents the same general shape, but not the ornamentation, which could be due to taphonomic processes.

\section{Paleoecology and distribution}

Microceratina azazoulensis Andreu \& Colin, 2005 is a marine, shelf to neritic species occurring in the following localities and stages: Andranomaimbo Formation, Madagascar, lower Cenomanian (Babinot et al. 2009); Aït Lamine Formation, Azazoul Basin, Morocco, middle-upper Cenomanian (Andreu Boussut 1991; Colin et al. 2005); and in the present work, Taquari Member, Riachuelo Formation, Sergipe Alagoas Basin, Brazil, middle-uppermost Albian, Aracajuia benderi (MSA-0) - Praebythoceratina amsittenensis subzone (MSA-0.3) - and Aracajuia antiqua (MSA-1) zones.

\section{Microceratina? sp. 1}

Fig. 7T

\section{Material examined}

BRAZIL: Porto dos Barcos 3 outcrop, Riachuelo Municipality, Sergipe State (sample MP-1470), approximate coordinates $10^{\circ} 43^{\prime} \mathrm{S}, 37^{\circ} 10^{\prime} \mathrm{W}$.

\section{Measurements}

Hypotype (CP-714): left valve: length $=0.41 \mathrm{~mm}$, height $=0.24 \mathrm{~mm}$. 


\title{
Remarks
}

Microceratina? sp. 1 vaguely resembles other species of Microceratina in Colin et al. (2005) in general shape (which is incomplete in the present specimen). Its ornamentation, however, bears no resemblance to any of the aforementioned, and for this reason it is only tentatively placed in this genus.

\section{Paleoecology and distribution}

Microceratina? sp. 1 is a marine, outer shelf species occurring in the Taquari Member, Riachuelo Formation, Sergipe-Alagoas Basin, Brazil, middle Albian, Aracajuia benderi zone (MSA-0), Praebythoceratina amsittenensis subzone (MSA-0.3).

\author{
Superfamily Trachyleberidoidea Sylvester-Bradley, 1948 \\ Family Cytherettidae Triebel, 1952 \\ Subfamily Cytherettinae Triebel, 1952 \\ Tribe Protocytherini Ljubimova, 1955
}

Veenia Butler \& Jones, 1957

Veenia guianensis Swain, 1976

Fig. 9B-D

Veenia guianensis Swain, 1976: 748, pl. 1, fig. 22, pl. 3, figs 1a-b, 3.2-3.5, 3.10.

Veenia guianensis - Viviers et al. 2000: 437, figs 23.1-23.2.

Veenia (Protoveenia) cf. florentinensis Damotte, 1961 - Andreu-Boussut 1991: 677, figs 49.5-49.8.

Veenia aff. sp. GA D 16 - Viviers et al. 2000: 414, fig. 22.11.

\section{New material examined}

BRAZIL: Massapê outcrop, Riachuelo Municipality, Sergipe State (samples MP-1545 and MP-1546), approximate coordinates $10^{\circ} 06^{\prime} \mathrm{S}, 37^{\circ} 10^{\prime} \mathrm{W}$.

\section{Type locality and stratum}

Leg 14, 144 well, core no. 6, section no. 1, at 58-64 cm depth, Guyana; upper Aptian-Cenomanian.

\section{Measurements}

Hypotype (CP-732): carapace: length $=0.57 \mathrm{~mm}$, height $=0.30 \mathrm{~mm}$, width $=0.27 \mathrm{~mm}$.

\section{Remarks}

The diagnosis follows Swain (1976). Veenia (Protoveenia) cf. florentinensis Damotte, 1961 in AndreuBoussut (1991) is in fact Veenia guianensis, just as part of the specimens identified as Veenia guianensis and Veenia aff. sp. GA D 16 in Viviers et al. (2000).

Fig. 9. [facing page] Ostracods of the Riachuelo Formation, Sergipe-Alagoas Basin, Albian, Brazil. A. Sergipella viviersae Do Carmo et al., 2012; CP-728, right lateral view. - B-D. Veenia guianensis Swain, 1976; CP-732. B. Right lateral view. C. Left lateral view. D. Dorsal view. - E. Reticulocosta edrianae Antonietto et al., 2015; CP-800, right lateral view. - F-K. Brachycythere smithsoniana sp. nov. F. CP-721, right lateral view. G. CP-723, left lateral view. H. CP-724, dorsal view. I. CP-726, dorsal view. J. CP-722, right lateral view. K. CP-725, left internal view. Scale bars $=100 \mu \mathrm{m}$. 


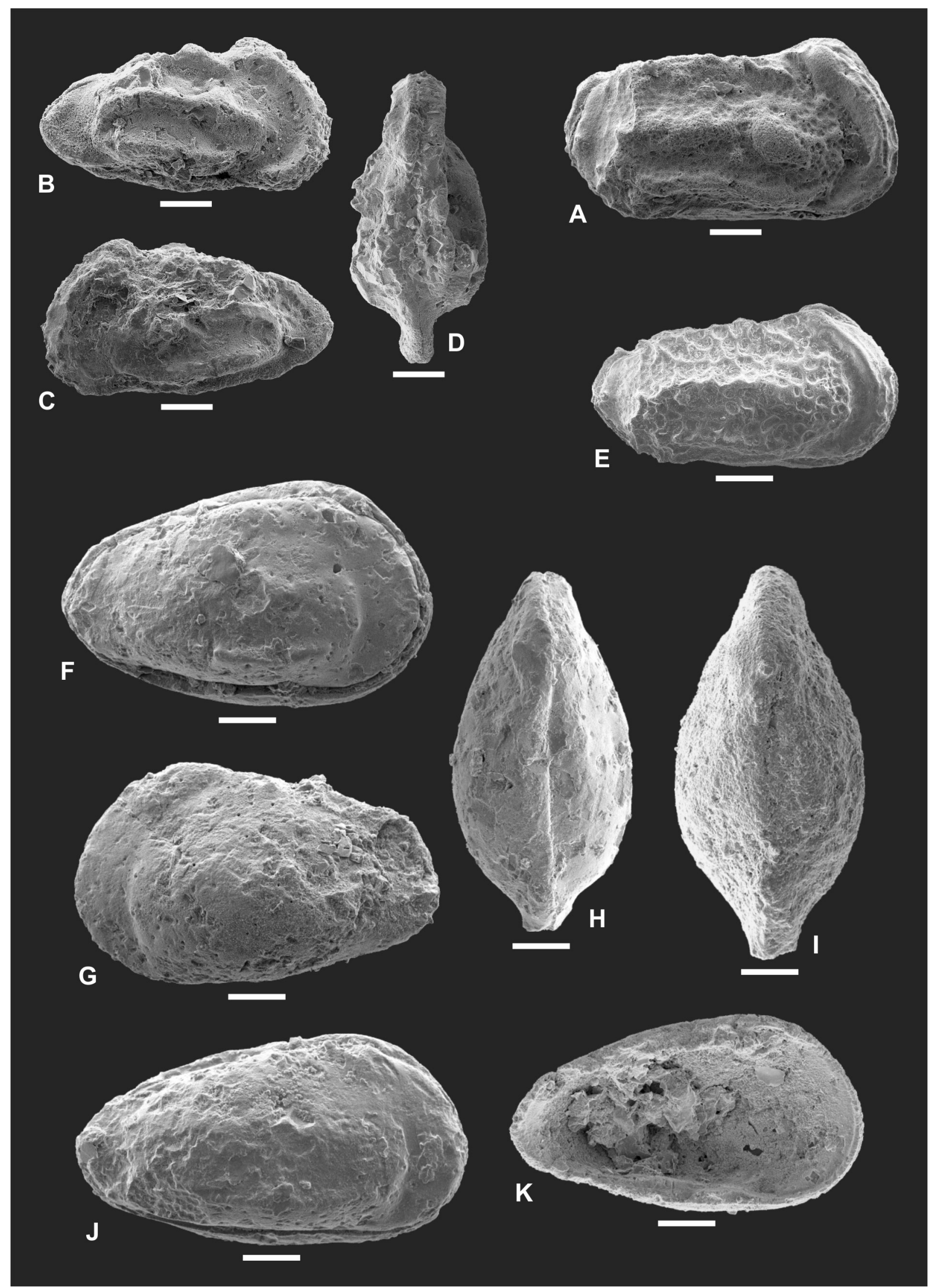




\section{Paleoecology and distribution}

Veenia guianensis is a marine, shelf species occurring in the following localities and stages: Guiana, upper Aptian-Cenomanian (Swain 1976); Jbel El Hajer and El Jir Formations and Azazoul Basin, Morocco, Albian (Andreu-Boussut 1991); Ponta do Mel Formation, Potiguar Basin, middle-upper Albian (Viviers et al. 2000); and in the present work, Maruim Member, Riachuelo Formation, Sergipe-Alagoas Basin, uppermost Albian, Aracajuia antiqua zone (MSA-1), Brazil.

\section{Subfamily Palaeocytherideinae Ljubimova, 1955}

Tribe Cytherettini Triebel, 1952

Reticulocosta Gründel, 1974

Reticulocosta edrianae Antonietto et al., 2015

Fig. 9E

Reticulocosta edrianae Antonietto et al., 2015: 361, fig. 4a-1.

Veenia guianensis Swain, 1976 - Viviers et al. 2000: 413, fig. 22.10.

Veenia sp. P1 - Viviers et al. 2000: 410, figs 23.3-23.4.

\section{Material examined}

BRAZIL: Estre outcrop, Rosário do Catete Municipality, Sergipe State (samples MP-1423 and MP1424), approximate coordinates $10^{\circ} 41^{\prime} \mathrm{S}, 37^{\circ} 02^{\prime} \mathrm{W}$; Fazenda Santa Bárbara outcrop, Rosário do Catete Municipality, Sergipe State (samples MP-1419 and MP-1420), approximate coordinates 10 $10^{\circ} 9^{\prime}$ S, $37^{\circ} 01^{\prime} \mathrm{W}$; P384 outcrop, Riachuelo Municipality, Sergipe State (samples MP-1496, MP-1497, MP-1499,

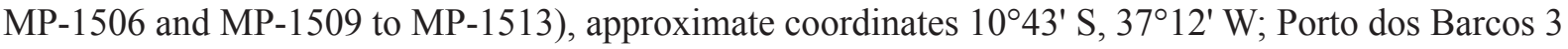
outcrop, Riachuelo Municipality, Sergipe State (samples MP-1460 to MP-1466, MP-1468 to MP-1472, MP-1474 to MP-1477, MP-1481 and MP-1482), approximate coordinates $10^{\circ} 43^{\prime} \mathrm{S}, 37^{\circ} 10^{\prime} \mathrm{W}$.

\section{Type locality and stratum}

Sample MP-1461, Porto dos Barcos 3 outcrop, Riachuelo Municipality, Sergipe State, Brazil, approximate coordinates: $10^{\circ} 43^{\prime} \mathrm{S}, 37^{\circ} 10^{\prime} \mathrm{W}$; Riachuelo Formation, Sergipe-Alagoas Basin, middle Albian, Aracajuia benderi zone (MSA-0), Praebythoceratina amsittenensis subzone (MSA-0.3) (Antonietto et al. 2015).

\section{Measurements}

Homotype (CP-800): ${ }^{\lambda}$, carapace: length $=0.50 \mathrm{~mm}$, height $=0.30 \mathrm{~mm}$, width $=0.28 \mathrm{~mm}$.

\section{Remarks}

The diagnosis follows Antonietto et al. (2015).

\section{Paleoecology and distribution}

Reticulocosta edrianae Antonietto et al., 2015 is a marine, shelf species occurring in the following localities and stages: Açu Formation, Potiguar Basin, middle Albian; and Maruim (Viviers et al. 2000) and Taquari (Antonietto et al. 2015) Members, Riachuelo Formation, Sergipe-Alagoas Basin, middle Albian, Aracajuia benderi zone (MSA-0), Praebythoceratina amsittenensis (MSA-0.3) and Reticulocosta edrianae (MSA-0.4) subzones, Brazil. 
ANTONIETTO L.S. et al., Brazilian latest Aptian-Albian marine ostracods

Family Trachyleberididae Sylvester-Bradley, 1948

Subfamily Brachycytherinae Puri, 1954

Brachycythere Alexander, 1933 emend. Puckett 2002

Brachycythere smithsoniana sp. nov.

urn:1sid:zoobank.org:act:92A99BD1-9BB2-457D-8329-8CA4E3ADC881

Fig. $9 \mathrm{~F}-\mathrm{K}$

“Veenia" GAD 34 - Grosdidier 1979: 8, fig. 28a-c.

\section{Diagnosis}

A species of Brachycythere distinguished by the following features: in lateral view, subtriangular to subelliptical carapace, with greatest height at the antero-central and greatest length at the central regions. Left valve is larger than the right, overlapping it markedly through the entire free margin, except at the postero-ventral margin, where the overlap is modest. Ornamentation differing from left to right valves: in the right one, it consists of three weakly distinguishable smooth ribs at dorsal, central and centroventral positions; the left one is entirely smooth.

\section{Etymology}

Named for the Smithsonian Institution, the organization to which the National Museum of Natural History of Washington, D.C. belongs, where an important part of this work was carried out.

\section{Type material}

\section{Holotype}

BRAZIL: +, carapace, stored dry in a micropaleontological slide (CP-721).

\section{Allotype}

BRAZIL: ${ }^{\lambda}$, carapace, stored as the holotype (CP-722).

\section{Paratypes}

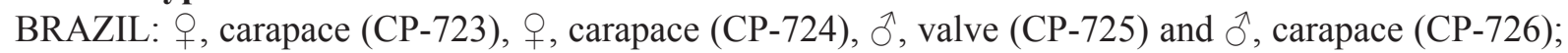
stored as the holotype.

\section{Other material examined}

BRAZIL: Massapê outcrop, Riachuelo Municipality, Sergipe State (samples MP-1514, MP-1516 to MP-1520, MP-1522, MP-1542, MP-1543 and MP-1545 to MP-1547), approximate coordinates $10^{\circ} 06^{\prime} \mathrm{S}, 37^{\circ} 10^{\prime} \mathrm{W}$.

\section{Type locality and stratum}

Sample MP-1515, Massapê outcrop, Riachuelo Municipality, Sergipe State, Brazil, approximate coordinates: $10^{\circ} 06^{\prime} \mathrm{S}, 37^{\circ} 10^{\prime} \mathrm{W}$; Riachuelo Formation, Sergipe-Alagoas Basin, uppermost Albian, Aracajuia antiqua zone (MSA-1).

\section{Measurements}

Holotype (CP-721): $q$, carapace: length $=0.65 \mathrm{~mm}$, height $=0.39 \mathrm{~mm}$, width $=0.28 \mathrm{~mm}$. Allotype (CP-722): 0 , carapace: length $=0.66 \mathrm{~mm}$, height $=0.35 \mathrm{~mm}$, width $=0.31 \mathrm{~mm}$. Paratype (CP-723): , , carapace: length $=0.64 \mathrm{~mm}$, height $=0.39 \mathrm{~mm}$, width $=0.31 \mathrm{~mm}$. Paratype (CP-724): , , carapace: length $=0.63 \mathrm{~mm}$, height $=0.37 \mathrm{~mm}$, width $=0.30 \mathrm{~mm}$. 
Paratype (CP-725): possible +, left valve: length $=0.62 \mathrm{~mm}$, height $=0.35 \mathrm{~mm}$.

Paratype (CP-726): $\hat{O}^{\lambda}$, carapace: length $=0.69 \mathrm{~mm}$, height $=0.38 \mathrm{~mm}$, width $=0.33 \mathrm{~mm}$.

\section{Description}

In lateral view, subtriangular carapace, with greatest height at antero-central and greatest length at central regions. Left valve larger than right valve, overlapping it pronouncedly through entire free margin, except at postero-ventral margin, where overlap is discrete. Round anterior end, becoming more rectilinear close to dorsal margin, where a slightly obtuse cardinal angle is formed. Lightly pointed posterior end, forming small caudal process, rectilinear below and above its rounded, more extreme point; with dorsal margin it forms an obtuse cardinal angle. Rectilinear to slightly concave dorsal margin. Rounded ventral margin, with slightly conspicuous concavity at oral region at left valve. Ornamentation differing from left to right valves: in right one three weakly distinguishable smooth ribs at dorsal, central and centroventral position: the generally curved dorsal one runs from centro-posterior to antero-dorsal region, slightly projecting behind dorsal margin at antero-dorsal region; central one runs from postero-central to central region; lightly curved ventral one runs from postero-ventral to antero-ventral region. Left valve entirely smooth. Flattened anterior and posterior regions. Weakly developed elliptical eye tubercle. In dorsal view, elliptical, with greatest width at centro-posterior region; pointed anterior and posterior ends. In internal view, holamphidont hinge, composed in left valve of frontal rounded socket and smaller, rounded bilobate tooth, a central smooth bar and a posterior elliptical, elongate socket. Well-developed inner lamella, not visible in oral region, where valve margin bends inwards expressively. Selvage not visible at postero-ventral and postero-central regions. Mild sexual dimorphism: females shorter in dorsal view and more rounded in lateral view than males, presenting more valve overlap through carapace margins than males.

\section{Remarks}

The suprageneric diagnosis follows Puckett (2002). Brachycythere smithsoniana sp. nov. presents the very distinctive feature among species of Brachycythere of having differences in ornamentation between its left and right valves as following: the right valve presents three weakly distinguishable ribs in dorsal, central and ventral positions, while the left is smooth. Brachycythere asymmetrica Puckett, 1994 also has dissimilar ornamentation between its left and right valves, but in a different pattern: in this species, only a ventral rib is present and this in both valves, although developed in varied levels from left to right; it is also distinct between male and females of the species (Puckett 1994). "Veenia" GAD 34 in Grosdidier (1979) is co-specific to Brachycythere smithsoniana sp. nov.

\section{Paleoecology and distribution}

Brachycythere smithsoniana sp. nov. is a marine, shelf species occurring in the following localities and stages: Madiéla Formation, Gabon Basin, Gabon, upper Aptian-middle Albian (Grosdidier 1979); and in the present work, Angico, Maruim and Taquari Members, Riachuelo Formation, Sergipe-Alagoas Basin, Brazil, uppermost Albian, Aracajuia antiqua zone (MSA-1).

Subfamily Trachyleberidinae Sylvester-Bradley, 1948

Algeriana Majoran, 1989

Algeriana? sp. 1

Fig. $7 \mathrm{U}$

\section{Material examined}

BRAZIL: Fazenda Santa Bárbara outcrop, Rosário do Catete Municipality, Sergipe State (sample MP1419), approximate coordinates $10^{\circ} 39^{\prime} \mathrm{S}, 37^{\circ} 01^{\prime} \mathrm{W}$. 


\section{Measurements}

Hypotype (CP-727): left valve: length $=0.57 \mathrm{~mm}$, height $=0.28 \mathrm{~mm}$.

\section{Remarks}

The generic diagnosis partially follows Majoran (1989). The main difference between the present specimen and previously described nominal species of Algeriana is the presence in the former of an additional anterior sub-marginal ridge originating in the eye tubercle. Due to the restricted number of specimens, it is not possible to make any further comments on the taxonomic placement of Algeriana? sp. 1.

\section{Paleoecology and distribution}

Algeriana? sp. 1 is a marine, shelf species occurring in the Taquari Member, Riachuelo Formation, Sergipe-Alagoas Basin, Brazil, middle Albian, Aracajuia benderi zone (MSA-0), Praebythoceratina amsittenensis subzone (MSA-0.3).

Quasihermanites Gründel, 1964

Quasihermanites? sp. 1

Fig. 8E-F

\section{Material examined}

BRAZIL: Estre outcrop, Rosário do Catete Municipality, Sergipe State (samples MP-1423 and MP1424), approximate coordinates $10^{\circ} 41^{\prime} \mathrm{S}, 37^{\circ} 02^{\prime} \mathrm{W}$.

\section{Measurements}

Hypotype (CP-715): left valve: length $=0.43 \mathrm{~mm}$, height $=0.25 \mathrm{~mm}$.

Hypotype (CP-766): right valve: length $=0.38 \mathrm{~mm}$, height $=0.23 \mathrm{~mm}$.

\section{Remarks}

The generic diagnosis follows Gründel (1964) and the suprageneric diagnosis follows Gründel (1966). The figured specimens are apparently less ornamented than other species of Quasihermanites Gründel, 1964, especially with regard to its characteristic lateral ribs (Kuznetsova 1961; Gründel 1964; Donze 1965; Pokorný 1973; Colin 1974; Babinot et al. 1985a; Babinot \& Colin 2011). The probable reason for that would be diagenesis, similar to that observed in the type material of Quasihermanites spiralus Schudack \& Schudack, 2000 (Schudack \& Schudack 2000). Therefore, the present authors classify it questionably as Quasihermanites.

\section{Paleoecology and distribution}

Quasihermanites? sp. 1 is a marine, shelf species occurring in the Taquari Member, Riachuelo Formation, Sergipe-Alagoas Basin, Brazil, middle Albian, Aracajuia benderi zone (MSA-0), Praebythoceratina amsittenensis subzone (MSA-0.3).

Sergipella Krömmelbein, 1967 emend. Do Carmo et al. 2012

Sergipella viviersae Do Carmo et al., 2012

Fig. 9A

Sergipella viviersae Do Carmo et al., 2012: 10, figs 2.1-2.7. 
Sergipella transatlantica Krömmelbein, 1967. - Viviers et al. 2000: 437, figs 23.12-23.13.

Sergipella aff. viviersae - Piovesan et al. 2013: 249, fig. 5.9a-b.

\section{New material examined}

BRAZIL: 1-CPB-1 well, Carmópolis Municipality, Sergipe State (depths of 348, 348.5 and 364.5 m); 1-US-1 well, Laranjeiras Municipality, Sergipe State (depths of 951, 1146 and $1200 \mathrm{~m}$ ); Penha outcrop, Riachuelo Municipality, Sergipe State (samples MP-1449 to MP-1453, MP-1456, MP-1457 and MP1459), approximate coordinates $10^{\circ} 42^{\prime} \mathrm{S}, 37^{\circ} 13^{\prime} \mathrm{W}$; São José 1 outcrop, Riachuelo Municipality, Sergipe State (samples MP-1550 to MP-1576, MP-1578, MP-1680 and MP-1694 to MP-1698), approximate coordinates $10^{\circ} 44^{\prime} \mathrm{S}, 37^{\circ} 13^{\prime} \mathrm{W}$.

\section{Type locality and stratum}

Sample MP-1157, São José 1 outcrop, Riachuelo Municipality, Sergipe State, Brazil, approximate coordinates: $10^{\circ} 44^{\prime} \mathrm{S}, 37^{\circ} 13^{\prime} \mathrm{W}$; Riachuelo Formation, Sergipe-Alagoas Basin, lower Albian, Aracajuia benderi zone (MSA-0), Sergipella viviersae subzone (MSA-0.2).

\section{Measurements}

Homeotype (CP-728): ${ }^{\lambda}$, carapace: length $=0.65 \mathrm{~mm}$, height $=0.35 \mathrm{~mm}$, width $=0.31 \mathrm{~mm}$.

\section{Remarks}

The diagnosis follows Do Carmo et al. (2012).

\section{Paleoecology and distribution}

Sergipella viviersae Do Carmo et al., 2012 is a transitional to marine (shelf) species occurring in the following localities and stages: São Mateus Formation, Espírito Santo Basin, Albian (Piovesan et al. 2013); and Riachuelo Formation, Sergipe-Alagoas Basin, upper Aptian-lower Albian, Aracajuia benderi zone (MSA-0), Harbinia sinuata? (MSA-0.1) and Sergipella viviersae (MSA-0.2) subzones (Viviers et al. 2000; Do Carmo et al. 2012); in the present work, restricted to the Angico and Taquari Member of the aforementioned formation, Brazil.

\section{Discussion}

\section{Taxonomic summary}

The present taxonomic study reviews the identification of the ostracod species found in the Angico, Taquari and Maruim Members of the Riachuelo Formation. Thirty-nine species of 25 genera in 16 families were found and the new taxa include a genus, Gabonorygma gen. nov., and three species: Praebythoceratina deltalata sp. nov., Gabonorygma sergipana gen. et sp. nov. and Brachycythere smithsoniana sp. nov. Other species in the present samples include Conchoecia? sp. 1, Cytherella sp. 1, C. besrineensis comb. nov., Cytherelloidea aff. globosa, C. btaterensis, Bairdoppilata sp. 1, Bairdoppilata sp. 2, B. comanchensis comb. nov., B. pseudoseptentrionalis, Robsoniella falklandensis, Cetacella sp. 1, Paracypris eniotmetos, Harbinia sinuata?, H. crepata, Liasina sp. 1, Praebythoceratina amsittenensis comb. nov., P. trinodosa comb. nov., Patellacythere shimonensis comb. nov., Patellacythere sp. 1, Xestoleberis? sp. 1, Xestoleberis? sp. 2, Apatocythere? sp. 1, Neocythere? aff. pseudovanveeni, N. (Physocythere) tenuis, Aracajuia antiqua comb. nov., A. benderi, A. fragilis comb. nov., Eocytheropteron sp. 1, Metacytheropteron aff. minuta, Microceratina? sp. 1, $M$. azazoulensis, Veenia guianensis, Algeriana? sp. 1, Quasihermanites? sp. 1 and Sergipella viviersae. 


\section{Paleoecology}

According to Campos Neto et al. (2007), the sediments of the Riachuelo Formation were deposited during the drift phase of the proto-South Atlantic Ocean. The sedimentary basin evolved from an initially transitional (local late Alagoas) to an initial shelf system (early Albian) and then gradually to more open sea habitats (late Albian-Cenomanian). This is evidenced by the temporal and spatial distributions of

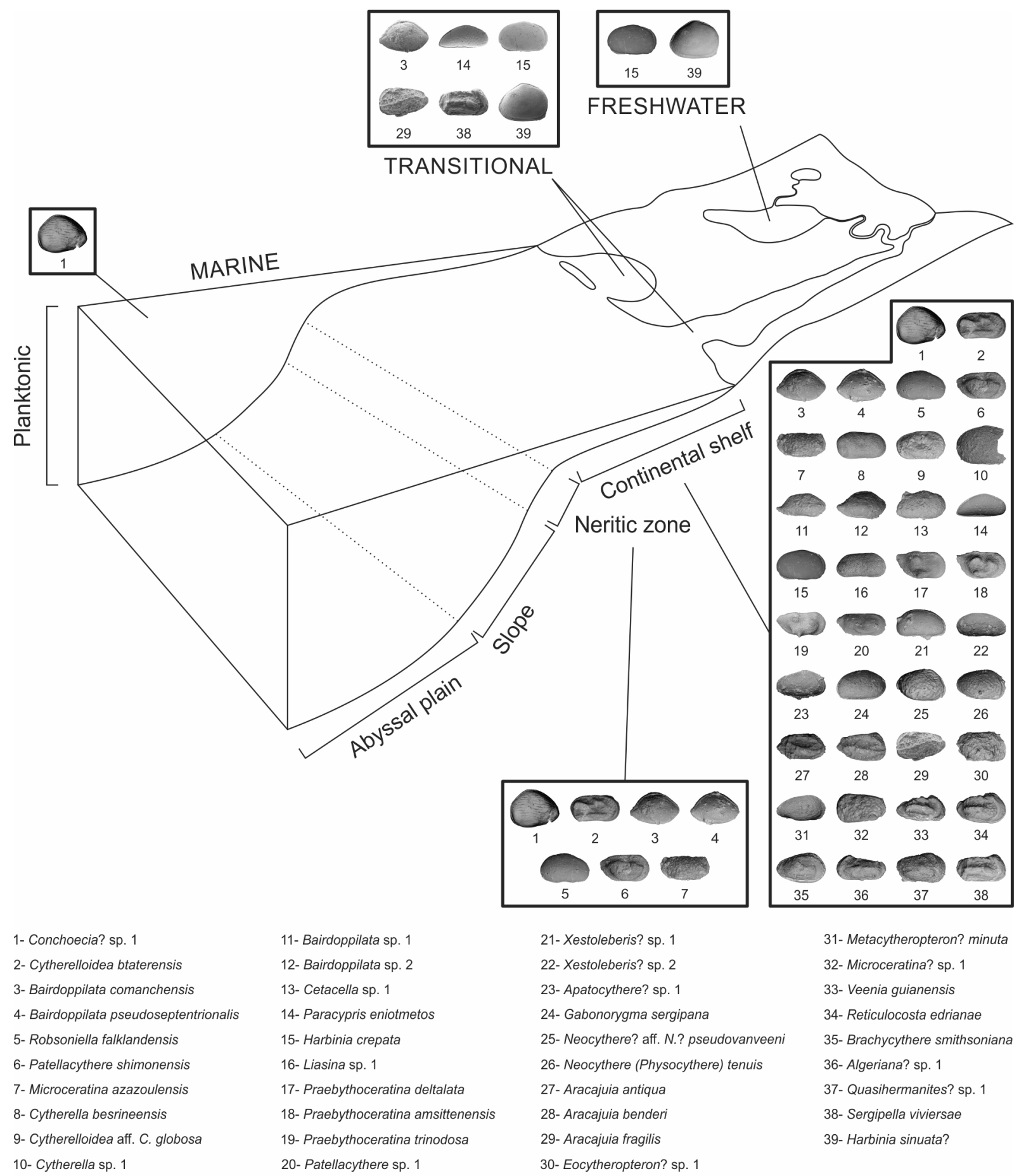

Fig. 10. Paleoenvironmental distributions of the ostracod species from the upper Aptian-Albian of the Riachuelo Formation, Sergipe-Alagoas Basin, northeastern Brazil. 
the Angico, Maruim and Taquari Members, which respectively represent inner shelf, reef and outer shelf shallow marine deposits (the Taquari Member also preserves lagoon and back reef environments).

Paleoecological data of the Albian species herein found (Fig. 10) endorse the lithological interpretations above, as 38 of the 39 identified species displayed shallow marine life habits, according to the literature. This is coincident with the paleoenvironments mainly observed in the Albian of the Riachuelo Formation. Seven species were also characteristic of moderately deep waters, and five were transitional (two of them even freshwater). However, our data are not perfectly congruent with data pertaining to the stratigraphic occurrence, because species living in the transitional zone do not necessarily occur in strata expected to be more transitional (MSA-0.1 and MSA-0.2 subzones). Moderately deep species are also equally found in both transitional and shallow marine to moderately deep marine strata (MSA-0.3, MSA-0.4 and MSA- 0.5 subzones and MSA-1 zone). Therefore, further analysis of additional data is needed to elucidate the distribution of these species in late Aptian-Albian strata of the Riachuelo Formation.

\section{Acknowledgements}

The authors wish to thank CNPq, associated with the "Serviço de Compras Internacionais" of the University of Brasilia, for the acquisition of our scanning electron microscope (SEM). We are also grateful to the University of Brasilia (UnB) for financial support for the visit to Petrobras, and to CENPES for technical support with core sample slides (J.L. Grillo) and SEM photography (R.S.M. da Costa) during this visit. Many thanks go to the "Agência Nacional do Petróleo, Gás Natural e Biocombustíveis" (ANP), Petrobras and the "Fundação de Empreendimentos Científicos e Tecnológicos" (FINATEC) for financial support for field work in the Sergipe-Alagoas Basin, through the OSTRAKi project. L.S. Antonietto wishes to thank "Coordenação de Aperfeiçoamento de Pessoal de Nível Superior" (CAPES) for granting support through the "Programa de Doutorado Sandwich no Exterior" (PDSE), which allowed most of the work to be carried out at NMNH from July 2013 to July 2014; and the board of the Institute of Geosciences, University of Brasilia, for all their cooperation throughout the process. He is also very grateful to FINATEC for financial support to attend the $4^{\text {th }}$ International Palaeontological Congress held in Mendoza, Argentina. Last, but not least, his regards go to C.E. Sanford, staff member of the NMNH Paleobiology Department, for all the help (and great, joyful moments) during his stay in Washington, D.C. and to S.C. Moreira, for the review of our manuscript's English language standards.

\section{References}

Alexander C.I. 1929. Ostracoda of the Cretaceous of north Texas. Texas University Bulletin 2907: 1-137.

Alexander C.I. 1932. Sexual dimorphism in fossil Ostracoda. American Midland Naturalist 13 (5): 302-310.

Alexander C.I. 1933. Shell structure of the ostracode genus Cytheropteron, and fossil species from the Cretaceous of Texas. Journal of Paleontology 7 (2): 181-214.

Alexander C.I. 1934. Ostracoda of the genera Monoceratina and Orthonotacythere from the Cretaceous of Texas. Journal of Paleontology 8 (1): 57-67.

Andreu B. 1992. Associations d'ostracodes et paléoécologie du Crétacé (Barrémien à Turonien) le long d'une transversale Agadir-Nador (Maroc). Palaeogeography, Palaeoclimatology, Palaeoecology 99: 291-319. http://dx.doi.org/10.1016/0031-0182(92)90020-6

Andreu B. \& Bilotte M. 2006. Ostracodes du Cénomanien supérieur et du Turonien de la zone souspyrénéenne orientale (Corbières méridionales, SE France). Systématique, biostratigraphie, paléoécologie et paléobiogéographie. Revue de Micropaléontologie 49: 55-73. http://dx.doi.org/10.1016/j. revmic.2005.12.001 
Andreu-Boussut B. 1991. Les ostracodes du Crétacé moyen (Barrémien à Turonien), le long d'une transversale Agadir-Nador (Maroc). Strata 2 (14): 1-765.

Antonietto L.S., Abrahão A., Do Carmo D.A. \& Meireles R.P. 2013. Taxonomy, biostratigraphy and paleozoogeography of Amphicytherura Butler and Jones, Aracajuia Krömmelbein and Dinglecythere Antonietto et al., n. gen. (Crustacea, Ostracoda). Marine Micropaleontology 105: 1-17. http://dx.doi. org/10.1016/j.marmicro.2013.09.002

Antonietto L.S., Do Carmo D.A., Viviers M.C. \& Adôrno R.R. 2015. Biostratigraphic and paleozoogeographic review of the upper Aptian-Albian ostracods of Riachuelo Formation, SergipeAlagoas basin, Northeastern Brazil. Revista Brasileira de Paleontologia 18 (3): 355-368. http://dx.doi. org/10.4072/rbp.2015.3.02

Antonietto L.S., Gobbo S.R., Do Carmo D.A., Assine M.L., Morgado M.A., Fernandes C.C. \& Silva J.E.L. 2012. Taxonomy, ontogeny and paleoecology of two species of Harbinia Tsao, 1959 (Crustacea, Ostracoda) from the Santana Formation, Lower Cretaceous, northeastern Brazil. Journal of Paleontology 86 (4): 659-668. http://dx.doi.org/10.1666/11-012R.1

Babinot J.F. \& Colin J.P. 1988. Paleobiogeography of Tethyan Cretaceous Marine Ostracods. In: Hanai T., Ikeya N. \& Ishizaki K. (eds) Evolutionary Biology of Ostracoda: Its Fundamentals and Applications: 823-839. Developments in Palaeontology and Stratigraphy 11, Kodansha, Tokyo.

Babinot J.F. \& Colin J.P. 2011. Barremian ostracods from the Serre de Bleyton (Drôme, SE France). Annalen des Naturhistorischen Museums in Wien, Serie A 113: 735-775.

Babinot J.F., Colin J.P. \& Damotte R. 1985b. Crétacé supérieur. In: Oertli H.J. (ed.) Atlas des Ostracodes de France: 211-255. Bulletin des Centres de Recherche Exploration-Production Elf-Aquitaine, Mémoire 9, Société Nationale Elf-Aquitaine, Pau.

Babinot J.F., Colin J.P. \& Randrianasolo A. 2009. Les ostracodes de l'Albien-Turonien moyen de la région d'Antsiranana (Nord Madagascar): systématique, paléoécologie et paléobiogéographie. Carnets de Géologie 2009 (1): 1-25.

Babinot J.F., Damotte R., Donze P., Grosdidier E., Oertli H.J. \& Scarenzi-Carboni G. 1985a. Crétacé inférieur. In: Oertli H.J. (ed.) Atlas des Ostracodes de France: 163-209. Bulletin des Centres de Recherche Exploration-Production Elf-Aquitaine, Mémoire 9, Société Nationale Elf-Aquitaine, Pau.

Bassoulet J.P. \& Damotte R. 1969. Quelques ostracodes nouveaux du Cénomano-Turonien de l'Atlas Saharien occidental (Algérie). Revue de Micropaléontologie 12 (3): 130-144.

Bate R.H. 1972. Phosphatized ostracods with appendages from the lower Cretaceous of Brazil. Palaeontology 15 (3): 379-393.

Becker G. 1990. Eine Ostracoden-Fauna von Thüringer Gepräge aus dem unterkarbonischen Deckdiabas von Günterod (typicus-Zone; Dill-Mulde, Rechtsrheinisches Schiefergebirge, Blatt 5216 Oberscheld). Geologisches Jahrbuch Hessen 118: 29-52.

Becker G., Lord A.R. \& Malz H. 1989. In the footsteps of Griffith and M'Coy or, Lower Carboniferous Ostracoda from Ireland and the definition of the genus Bairdia M'Coy, 1844 (Part 1). Courier Forschungsinstitut Senckenberg 113: 29-36.

Benson R.H. \& Tatro J.O. 1964. Faunal description of Ostracoda of the Marlbrook Marl (Campanian), Arkansas. The University of Kansas Paleontological Contributions - Arthropoda 7: 1-32.

Bertels A. 1977. Cretaceous Ostracoda - South Atlantic. In: Swain F.M. (ed.) Stratigraphic Micropaleontology of Atlantic Basin and Borderlands: 271-304. Developments in Palaeontology and Stratigraphy 6, Elsevier, Amsterdam. 
Bischoff G. 1964. Ostracoden-Studien im Libanon, 3): Die Gattung Cytherelloidea im Oberen Jura und in der Unterkreide. Senckenbergiana Lethaea 45 (1-4): 1-27.

Bold W.A. van den. 1964. Ostracoden aus der Oberkreide von Abu Rawash, Ägypten. Palaeontographica, Abteilung A 123: 111-136.

Bonnema J.H. 1941. Ostracoden aus der Kreide des Untergrundes der nordöstlichen Niederlande. Natuurhistorisch Maandblad 29 (9-12): 91-95, 104-108, 115-118, 129-132; 30 (1-6): 8-12, 21-29, 40-43, 56-60, 70-71.

Brown P.M. 1957. Upper Cretaceous Ostracoda from northern Carolina. North Carolina Department of Conservation and Development Bulletin 70: 1-27.

Campos Neto O.P.A., Souza-Lima W. \& Cruz F.E.G. 2007. Bacia de Sergipe-Alagoas. Boletim de Geociências da Petrobras 15 (2): 405-415.

Coimbra J.C., Arai M. \& Carreño A.L. 2002. Biostratigraphy of Lower Cretaceous microfossils from the Araripe Basin, northeastern Brazil. Geobios 35 (6): 687-698. http://dx.doi.org/10.1016/S0016$\underline{6995(02) 00082-7}$

Colin J.P. 1974 Contribution à l'étude des ostracodes du Crétacé supérieur de Dordogne. Geobios 7 (1): 19-42. http://dx.doi.org/10.1016/S0016-6995(74)80017-3

Colin J.P. \& Andreu B. 1990. Cretaceous halocypridid Ostracoda. In: Whatley R. \& Maybury C. (eds) Ostracoda and Global Events: 515-526. Chapman \& Hall, Cambridge.

Colin J.P. \& Dépêche F. 1997. Faunes d'ostracodes lacustres des bassins intra-cratoniques d'âge alboaptien en Afrique de l'Ouest (Cameroun, Tchad) et au Brésil: considérations d'ordre paléoécologique et paléobiogéographique. Africa Geoscience Review 4 (3/4): 431-450.

Colin J.P., Andreu B., Dejax J. \& Gèze R. 2005. Sur l'origine du genre Microceratina Swanson, 1980 (Ostracoda, Eucytherurinae) et sa présence téthysienne dès le Jurassique supérieur. Revue de Micropaléontologie 48: 15-24. http://dx.doi.org/10.1016/j.revmic.2004.12.005

Crane M.J. 1965. Upper Cretaceous ostracodes of the Gulf Coast area. Micropaleontology 11 (2): 191254.

Damotte R. 1992. Data report: Cretaceous ostracodes from holes 761B and 764A (Wombat plateau) and holes 762C, 763B, and 763C (Exmouth plateau). In: Rad U., Haq B.U., Kidd R.B. \& O'Connell S. (eds) Exmouth Plateau: 819-834. Proceedings of the Ocean Drilling Program, Scientific Results 122, Ocean Drilling Program, College Station, Texas.

Damotte R. \& Fleury J.J. 1987. Ostracodes maastrichtiens et paléocènes du Djebel Dyr. Géologie Méditerranéenne 14 (2): 87-107.

Damotte R. \& Saint-Marc P. 1972. Contribution à la connaissance des ostracodes crétacés du Liban. Revista Española de Micropaleontología 4 (3): 273-296.

Deroo G., 1956. Études critiques au sujet des ostracodes marins du Crétacé inférieur et moyen de la Champagne humide et du Bas Boulonnais. Revue de l' Institut Français du Pétrole 11 (12): 1499-1535.

Dingle R.V. 1980. Marine Santonian and Campanian ostracods from a borehole at Richards Bay, Zululand. Annals of the South African Museum 82 (1): 1-70. Available from http://biodiversitylibrary. org/page/40752045 [accessed 9 Oct. 2016]

Dingle R.V. 1984. Mid-Cretaceous Ostracoda from Southern Africa and the Falkland Plateau. Annals of the South African Museum 93 (3): 97-211. Available from http://biodiversitylibrary.org/page/40693037 [accessed 9 Oct. 2016] 
Do Carmo D.A., Coimbra J.C., Whatley R.C., Antonietto L.S. \& Citon R.T.P. 2013. Taxonomy of limnic Ostracoda (Crustacea) from the Alagamar Formation, middle-upper Aptian, Potiguar Basin, northeastern Brazil. Journal of Paleontology 87 (1): 91-104. http://dx.doi.org/10.1666/11-108R.1

Do Carmo D.A., Colin J.P., Hidalgo P.H.P., Meireles R.P., Berbert-Born M.L.C. \& Almeida C.M. 2012. Reassessment of the genus Sergipella Krömmelbein, 1967 (Ostracoda, Trachyleberididae), uppermost Aptian-Albian of Brazil and West Africa: Taxonomy and paleogeographic distribution. Revue de Micropaléontologie 55: 3-15. http://dx.doi.org/10.1016/j.revmic.2011.12.002

Do Carmo D.A., Tomassi H.Z. \& Oliveira S.B.S.G. 2004. Taxonomia e distribuição estratigráfica dos ostracodes da Formação Quiricó, Grupo Areado (Cretáceo Inferior), Bacia Sanfranciscana, Brasil. Revista Brasileira de Paleontologia 7 (2): 139-149.

Do Carmo D.A., Whatley R., Neto J.V.Q. \& Coimbra J.C. 2008. On the validity of two Lower Cretaceous non-marine ostracode genera: biostratigraphic and paleogeographic implications. Journal of Paleontology 82: 790-799. http://dx.doi.org/10.1666/07-008.1

Donze P. 1964. Ostracodes berriasiens des massifs subalpins septentrionaux (Bauges et Chartreuse). Travaux du Laboratoire de Géologie de la Faculté des Sciences de Lyon 11: 103-158.

Donze P. 1965. Espèces nouvelles d'ostracodes des couches de base du Valanginien de Berrias (Ardèche). Travaux du Laboratoire de Géologie de la Faculté des Sciences de Lyon 12: 87-107.

El-Nady H., Abu-Zied R. \& Ayyad S. 2008. Cenomanian - Maastrichtian ostracods from Gabal Arif ElNaga anticline, Eastern Sinai, Egypt. Revue de Paléobiologie 27 (2): 533-573.

Feijó F.J. 1994. Bacias de Sergipe e Alagoas. Boletim de Geociências da Petrobras 8 (1): 149-161.

Gebhardt H. 1999. Cenomanian to Coniacian ostracodes from the Nkalagu area (SE Nigeria): biostratigraphy and palaeoecology. Paläontologische Zeitschrift 73 (1/2): 77-98. http://dx.doi. org/10.1007/BF02987984

Graddi J.C.S.V., Campos Neto O.P.A. \& Caixeta J.M. 2007. Bacia de Jacuípe. Boletim de Geociências da Petrobras 15 (2): 417-421.

Gramann F. 1963. Liasina n. gen. (Ostracoda) aus dem deutschen Lias. Geologisches Jahrbuch 82: $65-74$.

Gramm M.N. \& Kuznetsova Z.V. 1970. Sistematicheskoye polozheniye roda Robsoniella (Ostracoda). Paleontologicheskiy Zhurnal 3: 89-94.

Grekoff N. \& Deroo G. 1956. Algunos Ostrácodos del Cretácico medio del Norte de España. Boletín del Instituto Geológico y Minero de España 12 (31/32): 215-235.

Grosdidier E. 1979. Principaux ostracodes marins de l'intervale Aptien-Turonien du Gabon (Afrique Occidentale). Bulletin des Centres de Recherche Exploration-Production du Pétrole 3: 1-33.

Gründel J. 1964. Neue Ostracoden aus der deutschen Unterkreide II. Monatsberichte der Deutschen Akademie der Wissenschaften zu Berlin 8 (3): 849-858.

Gründel J. 1966. Taxonomische, biostratigraphische und variationstatistische Untersuchungen an den Ostracoden der Unterkreide in Deutschland. Freiberger Forschungshefte, Reihe C Geowissenschaften, Paläontologie 200: 1-105.

Gründel J. 1967. Neue Ostracoden aus dem Hauterive und Alb Deutschlands. Jahrbuch für Geologie 1: 629-650. 
Gründel J. 1974. Zur Taxonomie und Phylogenie der Cytherettidae Triebel, 1952 (Ostracoda, Crustacea). Freiberger Forschungshefte, Reihe C Geowissenschaften, Paläontologie 298: 81-99.

Gründel J. 1976. Zur Taxonomie und Phylogenie der Cytherurinae G.W. Müller, 1894 (Cytherocopina, Ostracoda) im Zeitraum höhere Trias bis Unterkreide. Zeitschrift für Geologischen Wissenschaften 4 (11): $1531-1541$.

Gründel J. 1977. Zur Phylogenie der Trachyleberidacea (Cytherocopina, Ostracoda). Freiberger Forschungshefte, Reihe C Geowissenschaften, Paläontologie 326: 33-43.

Gründel J. 1978a. Zur Taxonomie und Phylogenie der Cytherideidae Sars, 1925 (Cytherocopina, Ostracoda) mit Beiträgen zu den Krithidae Mandelstam, 1959. Schriftenreihe für Geologische Wissenschaften 10: 73-86.

Gründel J. 1978b. Bemerkungen zur Phylogenie der Cytherideidacea Sars, 1925 (Cytherocopina, Ostracoda). Zeitschrift für Geologische Wissenschaften 6 (10): 1251-1261.

Gründel J. \& Kozur H. 1971. Zur Taxonomie der Bythocytheridae und Tricorninidae (Podocopida, Ostracoda). Monatsberichte der Deutschen Akademie der Wissenschaften zu Berlin 13: 907-937.

Hanai T. 1970. Studies on the ostracod subfamily Schizocytherinae Mandelstam. Journal of Paleontology 44 (4): 693-729.

Hart M.B. 1973. A correlation of the macrofaunal and microfaunal zonations of the Gault Clay in southeast England. In: Casey R. \& Rawson P.F. (eds) The Boreal Lower Cretaceous: 267-288. Seel House, Liverpool.

Hart M.B. \& Crittenden S. 1985. Early Cretaceous Ostracoda from the Goban Spur; D.S.D.P. Leg 80, Site 549. Cretaceous Research 6: 219-233. http://dx.doi.org/10.1016/0195-6671(85)90047-3

Herrig E. 1966. Ostracoden aus der Weißen Schreibkreide (Unter-Maastricht) der Insel Rügen. Paläontologische Abhandlungen, Abteilung A 2 (4): 693-1024.

Holden J.C. 1964. Upper Cretaceous ostracods from California. Palaeontology 7 (3): 393-429.

Honigstein A., Raab M. \& Rosenfeld A. 1985. Manual of Cretaceous ostracodes from Israel. Israel Geological Survey, Special Publication 5: 1-25.

Hou Y. 1984. Guanyu Harbinia; Sinocypris; Quadracypris ji Nanxiongium si shu de fenlei wenti (qikan lunwen). Acta Micropaleontologica Sinica 9 (1): 17-34. [in Chinese]

Hou Y.T., Gou Y.X. \& Chen D.Q. 2002. Zhongguo Jie Xing Lei Huashi-Di Yi Juan 1-Cypridacea He Darwinulidacea. Science Press, Beijing.

Howe H.V. \& Laurencich L. 1958. Introduction to the Study of Cretaceous Ostracoda. Louisiana State University Press, Baton Rouge.

Ismail A.A. \& Soliman S.I. 1997. Cenomanian-Santonian foraminifera and ostracodes from Horus Well-I, north Western Desert, Egypt. Micropaleontology 43 (2): 165-183.

Jarvis I, Carson G.A., Cooper M.K.E., Hart M.B., Leary P.N., Tocher B.A., Horne D. \& Rosenfeld A. 1988. Microfossil assemblages and the Cenomanian-Turonian (late Cretaceous) oceanic anoxic event. Cretaceous Research 9: 3-103. http://dx.doi.org/10.1016/0195-6671(88)90003-1

Jones T.R. 1849. A Monograph of the Entomostraca of the Cretaceous Formation of England. C. \& J. Adlard, London.

Jones T.R. \& Hinde G.J. 1890. A Supplementary Monograph of the Cretaceous Entomostraca of England and Ireland. C. \& J. Adlard, London. 
Kaye P. 1963. The ostracod genus Neocythere in the Speeton clay. Palaeontology 6 (2): 274-281.

Kaye P. 1964. Revision of British marine Cretaceous Ostracoda with notes on additional forms. Bulletin of the British Museum (Natural History), Geology 10: 35-79. Available from http://biodiversitylibrary. org/page/36359458 [accessed 9 Oct. 2016]

Kaye P. 1965. Some new British Albian Ostracoda. Bulletin of the British Museum (Natural History), Geology 11: 215-253. Available from http://biodiversitylibrary.org/page/36675331 [accessed 9 Oct. 2016]

Keen M.C. \& Siddiqui Q.A. 1971. Cenomanian Ostracoda from the Carr's Glen shell bed of Belfast, Northern Ireland. Revue de Micropaléontologie 14 (1): 62-68.

Kempf E.K. 1986. Index and bibliography of marine Ostracoda. Sonderveröffentlichungen des Geologischen Instituts der Universität Köln 50: 1-762.

Kesling R.V. 1951. Terminology of ostracod carapaces. Contributions from the Museum of Paleontology, University of Michigan 1 (4): 93-171.

Kozur H. 1972. Einige Bemerkungen zur Systematik der Ostracoden und Beschreibung neuer Platycopida aus der Trias Ungarns und der Slowakei. Geologisch-Paläontologische Mitteilungen, Innsbruck 2: 1-27.

Krömmelbein K. 1962. Zur Taxonomie und Biochronologie stratigraphisch wichtiger Ostracoden-Arten aus der oberjurassich?-unterkretazischen Bahia-Serie (Wealden-Fazies) NE-Brasiliens. Senckenbergiana Lethaea 43 (6): 437-527.

Krömmelbein K. 1964. Ostracoden aus der marinen "Küsten-Kreide" Brasiliens. 1: Brachycythere (Brachycythere) sapucariensis n. sp. aus dem Turonium. Senckenbergiana Lethaea 45 (6): 489-495.

Krömmelbein K. 1966. Preliminary remarks on some marine ostracodes from northeastern Brazil and West Africa. In: Hinte J.E. (ed.) Proceedings of the Second West African Micropaleontological Colloquium: 119-123. E.J. Brill, Leiden.

Krömmelbein K. 1967. Ostracoden aus der marinen "Küsten-Kreide" Brasiliens. 2: Sergipella transatlantica n. g., n. sp., und Aracajuia benderi n. g., n. sp., aus dem Ober Aptium/Albium. Senckenbergiana Lethaea 48 (6): 525-533.

Krömmelbein K. \& Weber R. 1971. Ostracoden des Nordost-Brasilianischen Wealden. Beihefte zum Geologischen Jahrbuch 115: 1-93.

Kuznetsova Z.V. 1956. Rod Robsoniella Kuznetzova gen. nov. In: Kiparisovoy L.D., Markovskogo B.P. \& Radchenko G.P. (eds) Materialy Po Paleontologii - Novyye Semeystva i Rody: 119-120. Gosgeoltekhizdat, Moscow.

Kuznetsova Z.V. 1961. Ostrakody Melovykh Otlozheniy Severo-Vostochno Azerbaydzhana Stratigraficheskoye Znacheniye. Azerbaydzhana Gosudarstvennyy Izdatel'stvo, Baku.

Liebau A. 2005. A revised classification of the higher taxa of the Ostracoda (Crustacea). Hydrobiologia 538: 115-137. http://dx.doi.org/10.1007/s10750-004-4943-7

Lüttig G. 1962. Zoologische und paläontologische Ostracoden-Systematik. Paläontologische Zeitschrift 36 (1): 154-184.

Maddocks R.F. 1969. Revision of Recent Bairdiidae (Ostracoda). United States National Museum Bulletin 295: 1-126. Available from http://biodiversitylibrary.org/page/7898842 [accessed 9 Oct. 2016]

Majoran S. 1989. Mid-Cretaceous Ostracoda of northeastern Algeria. Fossil and Strata 27: 1-67. 
Marques R.C. 1965 Campo petrolífero de Carmópolis: histórico da descoberta - geologia do campo perspectivas econômicas. Boletim Técnico da Petrobras 8 (3): 307-328.

Martin G.P.R. 1958. Cetacella, eine neue Ostracoden-Gattung aus dem Kimmeridge Nordwestdeutschlands. Paläontologische Zeitschrift 32 (3/4): 190-196.

Mertens E. 1956. Zur Grenzziehung Alb/Cenoman in Nordwestdeutschland mit Hilfe von Ostracoden. Geologisches Jahrbuch, Reihe B 72: 174-230.

Morsi A.M.M., Faris M., Zalat A.E. \& Salem R.F.M. 2008. Maastrichtian-Early Eocene ostracodes from west-central Sinai, Egypt - taxonomy, biostratigraphy, paleoecology and paleobiogeography. Revue de Paléobiologie 27 (1): 159-189.

Moura J.A. 1988. Ostracods from non-marine Early Cretaceous sediments of the Campos Basin, Brazil, In: Hanai T., Ikeya N. \& Ishizaki K. (eds) Evolutionary Biology of Ostracoda: Its Fundamentals and Applications: 1207-1216. Developments in Palaeontology and Stratigraphy 11, Kodansha, Tokyo.

Moura J.A. \& Praça U.M. 1985. Ostracodes das seqüências não marinhas e transicionais Mesozóicas (Andares Jiquiá e Alagoas), Bacia de Campos. Coletânea de Trabalhos Paleontológicos - Série Geologia 27 (2): 401-408.

Moysey D.G. \& Maddocks R.F. 1982. Ostracoda and associated fauna of the lower Walnut Formation (lower Cretaceous) of Travis and Williamson counties, Texas. In: Maddocks R.F. (ed.) Texas Ostracoda: Guidebook of Excursions and Related Papers for the Eighth International Symposium on Ostracoda, July 24-25 and July 30-August 3, 1982: 143-165. Department of Geosciences, University of Houston, Houston.

Münster G. 1830. Ueber einige fossile Arten Cypris (Müller, Lamk.) und Cythere (Müller, Latreille, Desmarest). Jahrbuch für Mineralogie, Geognosie, Geologie und Petrefaktenkunde 1: 60-67.

Musacchio E.A. 1990. Non-marine Cretaceous ostracods from Argentina and their palaeobiogeographical relationships. In: Whatley R. \& Maybury C. (eds) Ostracoda and Global Events: 557-569. Chapman \& Hall, London.

Musacchio E.A. \& Simeoni M. 2008. Valanginian and Hauterivian marine ostracods from Patagonia (Argentina): correlations and palaeogeography. Revue de Micropaléontologie 51: 239-257. http:// dx.doi.org/10.1016/j.revmic.2007.07.001

Neale J.W. 1978. The Cretaceous. In: Bate R. \& Robinson E. (eds) A Stratigraphical Index of British Ostracoda: 325-384. Geological Journal Special Issue 8, Seel House Press, Liverpool.

Neale J.W. 1982. Aspects of the Subfamily Schulerideinae. In: Bate R.H., Robinson E. \& Sheppard L.M. (eds) Fossil and Recent Ostracods: 178-192. Ellis Horwood, Chichester.

Neufville E.M.H. 1973. Upper Cretaceous-Palaeogene ostracods from the South Atlantic. Publications from the Palaeontological Institution of the University of Uppsala, Special Volume 1: 1-205.

Oertli, H.J. 1957. Ostracodes du Jurassique Supérieur du Bassin de Paris (sondage Vernon 1). Revue de l'Institut Français du Pétrole 12 (6): 647-695.

Oertli H.J. 1963. Faunes d'Ostracodes du Mésozöique de France. E.J. Brill, Leiden.

Oertli H.J. 1974. Lower Cretaceous and Jurassic ostracods from DSDP Leg 27—a preliminary account. Deep Sea Drilling Project Initial Reports 27: 947-965.

Oertli H.J., Brotzen F. \& Bartenstein H. 1961. Mikropaläontologisch-feinstratigraphische Untersuchung der Jura-Kreide-Grenzschichten in Südschweden. Sveriges Geologiska Undersöknings Avhandlingar och Uppsatser, Serie C 55 (3): 1-24. 
Piovesan E.K., Ballent S. \& Fauth G. 2012. Cretaceous palaeogeography of southern Gondwana from the distribution of the marine ostracod Majungaella Grekoff: new data and review. Cretaceous Research 37: 127-147. http://dx.doi.org/10.1016/j.cretres.2012.03.013

Piovesan E.K., Bergue C.T. \& Fauth G. 2009. Cretaceous ostracodes from Pará-Maranhão Basin, Brazil: taxonomy and preliminary paleoecological and paleobiogeographical inferences. Revue de Paléobiologie 28 (2): 437-456.

Piovesan E.K., Nicolaidis D.D., Fauth G. \& Viviers M.C. 2013. Ostracodes from the Aptian-Santonian of the Santos, Campos and Espírito Santo Basins, Brazil. Journal of South American Earth Sciences 48: 240-254. http://dx.doi.org/10.1016/j.jsames.2013.09.012

Pokorný V. 1964. Conchoecia? cretacea n. sp., first fossil species of the family Halocyprididae (Ostracoda, Crustacea). Acta Universitatis Carolinae - Geologica 2: 175-180.

Pokorný V. 1973. The Ostracoda of the Klentnice Formation (Tithonian?) Czechoslovakia. Ústředni Ústav Geologický 1: 1-108.

Ponte F.C. \& Asmus H.E. 1976. The Brazilian marginal basins: current state of knowledge. Anais da Academia Brasileira de Ciências - Suplemento 48: 215-289.

Poropat S.F. \& Colin J.P. 2012. Reassessment of the Early Cretaceous non-marine ostracod genera Hourcqia Krömmelbein, 1965 and Pattersoncypris Bate, 1972 with the description of a new genus, Kroemmelbeincypris. Journal of Paleontology 86 (4): 699-719. http://dx.doi.org/10.1666/11-140R.1

Puckett T.M. 1994. New Ostracoda species from an Upper Cretaceous oyster reef, northern Gulf coastal plain, U.S.A.Journal of Paleontology 68 (6): 1321-1335. http://dx.doi.org/10.1017/S0022336000034302

Puckett T.M. 2002. Systematics and paleobiogeography of brachycytherine Ostracoda. Micropaleontology 48 (2): 1-87.

Puckett T.M., Colin J.P. \& Mitchell S. 2012. New species and genera of Ostracoda from the Maastrichtian (Late Cretaceous) of Jamaica. Micropaleontology 58 (5): 397-455.

Ramos M.I.F., Rossetti D.F. \& Paz J.D.S. 2006. Caracterização e significado paleoembiental da fauna de ostracodes da Formação Codó (NeoAptiano), leste da Bacia de Grajaú, MA, Brasil. Revista Brasileira de Paleontologia 9 (3): 339-348.

Reuss A.E. 1845. Die Versteinerungen der Böhmischen Kreideformation. Schweizerbart, Stuttgart.

Reyment R.A. 1981. West Africa. In: Reyment R.A. \& Bengtson P. (eds) Aspects of Mid-Cretaceous Regional Geology: 133-160. Academic Press, London.

Roemer F.A. 1841. Die Versteinerungen des Norddeutschen Kreidegebirges. Hahnsche Buchhandlung, Hannover.

Rosenfeld A. \& Raab M. 1974. Cenomanian-Turonian ostracodes from the Judea group in Israel. Geological Survey of Israel Bulletin 62: 1-64.

Rosenfeld A. \& Raab M. 1983. Lower Cretaceous ostracodes from Israel and Sinai. Israel Journal of Earth Sciences 33 (3): 85-134.

Schaller H. 1969. Revisão estratigráfica da bacia de Sergipe-Alagoas. Boletim Técnico da Petrobras 12 (1): 21-86.

Schenck E.T. \& McMasters J.H. 1956. Procedure in Taxonomy. Third Edition. Stanford University, Stanford. 
Schmidt R.A. 1948. Ostracoda from the Upper Cretaceous and Lower Eocene of Maryland, Delaware, and Virginia. Journal of Paleontology 22 (4): 389-431.

Schornikov E.I. 1990. Evolution and classification of Bythocytheridae. Courier Forschungsinstitut Senckenberg 123: 291-302.

Schornikov E.I. \& Mikhailova E.D. 1990. Ostrakody Bythocytheridae: Rannego Etapa, Razvitiya, Sravnitel'naya Morfologiya, Paleoekologiya, Puti Evolyutsii. Nauka, Moscow.

Schudack U. \& Schudack M.E. 2000. Ostracods from the Upper Jurassic (Oxfordian-Tithonian) of southern Germany. Journal of Micropalaeontology 19: 97-112. http://dx.doi.org/10.1144/jm.19.2.97

Shahin A. 1991. Cenomanian-Turonian ostracods from Gebel Nezzazat, southwestern Sinai, Egypt, with observations on $\delta^{13} \mathrm{C}$ values and the Cenomanian/Turonian boundary. Journal of Micropalaeontology 12 (2): 133-150. http://dx.doi.org/10.1144/jm.10.2.133

Silva-Telles Júnior A.C. \& Viana M.S.S. 1990. Paleoecologia dos ostrácodes da Formação Santana (bacia do Araripe): um estudo ontogenético de populações. In: Campos D.A., Viana M.S.S., Brito P.M. \& Beurlen G. (eds) Atas do $1^{\circ}$ Simpósio sobre a Bacia do Araripe e Bacias Interiores do Nordeste: 309328. Vol. 1. DNPM/SBP/SBG - Núcleo Nordeste, Fortaleza.

Smith R.J. 2000. Morphology and ontogeny of Cretaceous ostracods with preserved appendages from Brazil. Palaeontology 43 (1): 63-98. http://dx.doi.org/10.1111/1475-4983.00119

Souza-Lima W., Andrade E.J., Bengtson P. \& Galm P.C. 2002. A bacia de Sergipe-Alagoas: evolução geológica, estratigrafia e conteúdo fóssil. Phoenix, Edição Especial 1: 1-34.

Swain F.M. 1976. Lower and middle? Cretaceous Ostracoda from the Atlantic Ocean off Guiana and off West Africa. Journal of Paleontology 50 (4): 734-753.

Sylvester-Bradley P.C. \& Benson R.H. 1971. Terminology for surface features in ornate ostracodes. Lethaia 4 (3): 249-286. http://dx.doi.org/10.1111/j.1502-3931.1971.tb01924.x

Swain F.M. \& Brown P.M. 1964. Cretaceous Ostracoda from wells in the southeastern United States. Bulletin, North Carolina Division of Mineral Resources 78: 1-55.

Swain F.M. \& Brown P.M. 1972. Lower Cretaceous, Jurassic(?) and Triassic Ostracoda from the Atlantic coastal region. United States Geological Survey Professional Paper 795: 1-55.

Tesakova E.M. 2010. Novyye dannyye o Pozdnesantonskikh i Rannemaastrikhtskikh ostrakodakh Saratovskoy oblasti. Paleontologicheskiy Zhurnal 2010 (2): 47-56.

Triebel E. 1940. Die Ostracoden der deutschen Kreide. 3.*) Cytherideinae und Cytherinae aus der Unteren Kreide. Senckenbergiana 22 (3/4): 160-227.

Veen J.E. 1936. Die Cytheridae der Maastrichter Tuffkreide und des Kunrader Korallenkalkes von SüdLimburg - III. Die Gattungen Loxoconcha, Monoceratina, Paracytheridea, Xestoleberis, Cytheropteron und Cytherura. Natuurhistorich Maanblad 25: 21-23, 32-36, 42-45, 61-64, 69-71, 82-86, 98-101, $108-113$.

Viviers M.C., Koutsoukos E.A.M., Silva-Telles Jr. A.C. \& Bengtson P. 2000. Stratigraphy and biogeographic affinities of the late Aptian-Campanian ostracods of the Potiguar and Sergipe Basins in northeastern Brazil. Cretaceous Research 21: 407-455. http://dx.doi.org/10.1006/cres.2000.0205

Weaver P.P.E. 1982. Ostracoda from the British lower Chalk and Plenus Marls. Monograph of the Palaeontographical Society 562: 1-127. 
Wilkinson I.P. 1988. Ostracoda across the Albian/Cenomanian boundary in Cambridgeshire and Western Suffolk, Eastern England. In: Hanai T., Ikeya N. \& Ishizaki K. (eds) Evolutionary Biology of Ostracoda: Its Fundamentals and Applications: 1229-1244. Developments in Palaeontology and Stratigraphy 11, Kodansha, Tokyo.

Witte L., Lissenberg T. \& Schuurman H. 1992. Ostracods from the Albian/Cenomanian boundary in the Achterhoek area (eastern part of the Netherlands). Scripta Geologica 102: 33-84.

Manuscript received: 13 August 2015

Manuscript accepted: 8 June 2016

Published on: 17 November 2016

Topic editor: Christian de Muizon

Desk editor: Danny Eibye-Jacobsen

Printed versions of all papers are also deposited in the libraries of the institutes that are members of the EJT consortium: Muséum national d'Histoire naturelle, Paris, France; Botanic Garden Meise, Belgium; Royal Museum for Central Africa, Tervuren, Belgium; Natural History Museum, London, United Kingdom; Royal Belgian Institute of Natural Sciences, Brussels, Belgium; Natural History Museum of Denmark, Copenhagen, Denmark; Naturalis Biodiversity Center, Leiden, the Netherlands. 